\title{
Common-Sense Construction of Consumer Protection Acts
}

\author{
Victor E. Schwartz ${ }^{*} \&$ Cary Silverman ${ }^{* *}$
}

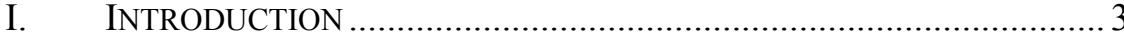

II. THE HISTORIC FOUNDATION OF CONSUMER PROTECTION

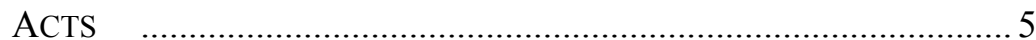

A. Consumer Protection Prior to the Twentieth Century .............. 6

B. Origin and Development of Federal Government Regulation and Enforcement ............................................................... 7

C. Why Congress Placed Enforcement Solely With the Government and Not With Private Lawyers Under the FTC Act

III. StATES Adopt CONSUMER PROTECTION LEGISLATION ............... 15

A. Elements Necessary to Bring a Private Claim ........................ 17

1. The Need to Show Reliance ............................................. 18

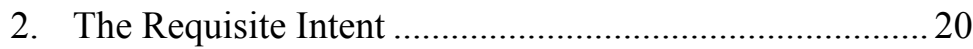

3. The Need to Show Injury In Fact and Damages.............. 21

B. Available Remedies ............................................................. 22

C. Availability of Recovery of Attorneys' Fees and Costs .......... 25

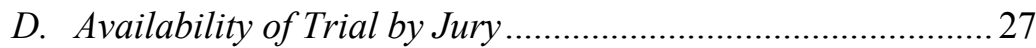

E. Availability and Restrictions on Class Action Lawsuits ........ 28

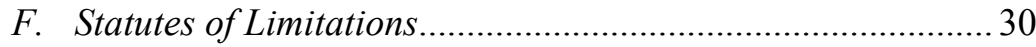

\footnotetext{
Victor E. Schwartz is Chairman of the Public Policy Group in the Washington, D.C., office of the law firm of Shook, Hardy \& Bacon L.L.P. He co-authors the most widely used torts casebook in the United States, Prosser, WADE AND SCHWARTZ'S TORTS (11th ed. 2005). He has served on the advisory committees of the American Law Institute's Restatement of the Law of Torts: Products Liability, Apportionment of Liability, and General Principles projects. Schwartz received his B.A. summa cum laude from Boston University and his J.D. magna cum laude from Columbia University. In 2003, he was named one of the nation's Legal Reform Champions by Chief Legal Executive magazine; the American Legislative Exchange Council, the nation's largest membership organization of state legislators, also named Schwartz the Private Sector Person of 2003.

Cary Silverman is an associate in the law firm of Shook, Hardy \& Bacon L.L.P. in Washington, D.C. He received a B.S. in Management Science from the State University of New York College at Geneseo in 1997, and an M.P.A. and a J.D. with honors from The George Washington University Law School in 2000, where he served as managing editor of The Environmental Lawyer.
} 
G. Miscellaneous Limitations and Exemptions............................31

IV. THE EXPANDED AND ABUSIVE Use of PRIVATE RightS OF ACTION Under STATE CONSUMER PROTECTION STATUTES........ 32

A. Case Study: California's Section 17200 ................................ 34

B. Stretching the Law Past its Limits to Attack Deep-Pocket and

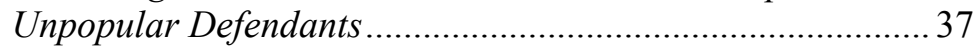

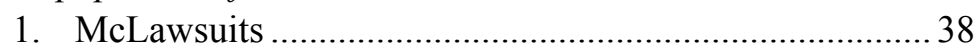

2. "Lights" Lawsuits ....................................................... 41

3. Blaming Alcoholic Beverage Advertisements for Illegal Underage Drinking. 46

4. Pharmaceutical Manufacturers: Failure to Disclose Alleged Product Defects as a Deceptive Act.................... 48

V. COMMON-SENSE CONSTRUCTION BY COURTS OF CONSUMER

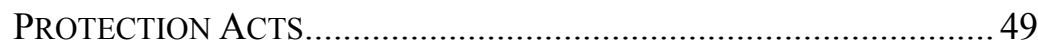

A. Requiring Injury in Fact ................................................... 50

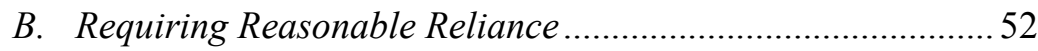

C. Factoring in Culpability ...................................................... 55

D. Requiring A Nexus Between the Misrepresentation and the Injury ...............................................................................5 56

E. Upholding Traditional Requirements for Class Action Certification and Preventing $a$ Windfall to Attorneys ........... 57

F. Placing Rational Limits on Extraterritorial Application ........ 61

G. Preventing Conversion of Product Liability and Other Claims into CPA Claims

VI. LEGISLATIVE INTERVENTION MAy BE NEEDED IN SOME

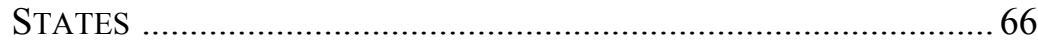

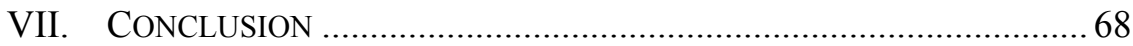

VIII. APPENDIX: AMERICAN LEGISLATIVE EXCHANGE COUNCIL, "MOdEL ACT ON PRIVATE ENFORCEMENT OF CONSUMER PRotection STATUTES" ............................................................ 69 


\section{INTRODUCTION}

State consumer protection acts (CPAs), often referred to as unfair and deceptive trade practices acts, are drafted in sweeping language, prohibiting all conduct that is "unfair" or "deceptive." States adopted these laws based on a similar federal statute, the Federal Trade Commission Act (FTC Act), in the 1960s and 1970s. The crucial difference between the FTC Act and CPAs is that most state laws, unlike the federal law, provide consumers with a private right of action. Unlike government agencies, private plaintiffs are not constricted to bringing actions in the public interest. They do not have to weigh the broad public-policy implications of their lawsuits or make judgments about how to expend limited resources. They do not have to answer to elected officials and the public. Unlike public enforcement, which is often injunctive in nature and meant to stop practices found to be unfair or deceptive, private actions punish businesses for conduct they may not have known was wrong.

In many states, the CPA is quite generous and provides a strong incentive to sue. The broad wording of these statutes, the hope that they will be construed liberally in favor of the consumer, and a dearth of case law make these open-ended statutes especially attractive to plaintiffs' lawyers who seek to circumvent traditional, rational requirements of the common law. CPAs often do not explicitly require the traditional elements of common law fraud and negligent misrepresentation claims, such as reliance, intent, injury, and damages. This allows lawyers to argue that proof of such basic elements is unnecessary and that plaintiffs should be able to receive a monetary award for a misleading advertisement, even if they never saw it. CPAs often allow recovery of statutory damages that can be far in excess of actual damages as well as an award of attorneys' fees. In some states, every prevailing plaintiff receives an award of three times the actual damages (treble damages), punishing the defendant even if it made an innocent mistake or did not realize its conduct violated the law.

As this Article will show, variations in statutory language and court interpretation of legislative intent have led to widely varying application of CPAs, despite their common origin and purpose. In many instances, CPAs have created liability or the threat of liability where none previously existed. This trend has accelerated in some quarters in recent years. A few judges have turned CPAs into springboards for a "universal tort," providing a claim in any lawsuit involving conduct that could possibly be categorized as unfair or deceptive. Claims that would 
traditionally have been brought as product liability, environmental, or contract claims are recast as violations of a consumer protection law and circumvent otherwise applicable and well-reasoned legal safeguards. It is irrelevant in some of these lawsuits that either the federal or state government permits the conduct attacked. This allows plaintiffs' lawyers - and judges who follow their leads - to regulate entire industries. For instance, private attorneys have used CPAs to attack the fast food industry for the nation's obesity problem and are reportedly planning to sue soft-drink makers for selling soda in schools. ${ }^{1}$ Creative plaintiffs' lawyers are using CPAs in cases involving medical laboratory billing practices and insurance policies. ${ }^{2}$ Plaintiffs have attempted to bring nationwide class actions, regardless of state statutes that vary widely in their requirements and remedies, in which they claim that "light" cigarette advertisements and packaging imply that cigarettes are healthy. ${ }^{3}$ Most recently, lawyers filed CPA claims against the dairy industry for its claims that milk is part of a healthy weight-loss program and against supermarkets and dairy companies for failing to warn about the effects of lactose intolerance on milk cartons. ${ }^{4}$

Judges have often resisted these extensions of existing law. The broad wording of these statutes leaves courts with the power to make reasoned choices. Courts can read a statute in the broadest sense, diluting or eliminating many of the fundamental elements of a tort claim and awarding damages regardless of causation or injury, or they can require plaintiffs to satisfy basic standing and proof requirements. Courts can award what are essentially punitive damages and attorneys' fees without a showing of bad conduct, or they can direct punishment only at those who intentionally deceive the public. Courts that reduce or eliminate the need to show reliance and damages can then lower the bar to certification of class action lawsuits, because these individual issues of fact are no longer relevant to a claim, or they can uphold procedural safeguards applicable to all class action litigation. Courts may follow the path of private plaintiffs and use CPAs as weapons in individual

1. See Pelman ex rel. Pelman v. McDonald's Corp., 396 F.3d 508 (2d Cir. 2005); Caroline E. Mayer, Lawyers Ready Suit Over Soda, WASH. POST, Dec. 2, 2005, at D4.

2. See James R. Keller, Illinois Consumer Fraud Act: A Primer on Recent Developments, 87 ILL. B.J. 474, $474 \mathrm{nn} .5$ \& 7 (1999) (citing Illinois cases).

3. See Blue Cross \& Blue Shield v. Philip Morris USA, 344 F.3d 211 (2d Cir. 2003) (appealing a judgment against defendant tobacco companies); Price v. Philip Morris, Inc., No. 00-L112, 2003 WL 22597608 (Ill. Cir. Ct. Mar. 21, 2003) (awarding \$10.1 billion), overruled on other grounds, 793 N.E.2d 942 (Ill. App. Ct. 2003), vacated, No. 96644, 2003 Ill. LEXIS 2625 (Ill. Sept. 16, 2003).

4. See infra note 203 
disputes, or they may require CPA claims to be in the public interest. Courts can choose to disrespect the interests of sister states by giving their state's CPA extraterritorial application, or they can limit use of the statute to protecting the interests of their own state's consumers.

Where judges have not placed reasonable limits on CPAs, voters have taken action to do so. For example, California voters, by a fiftynine percent majority, ${ }^{5}$ supported Proposition 64 in 2004, amending their consumer protection statute, Section $17200 .^{6}$ That law had resulted in a flood of "shakedown" lawsuits against small businesses for technical violations of state laws or regulations, such as using too small of a font size in advertisements, even when no one had been harmed. California voters realized that when left unchecked, CPAs have resulted in unfair, uncertain, unpredictable, and substantial liability for businesses, especially small ones.

After examining the history of the FTC Act and the variations of state CPAs, this Article suggests several steps courts can take in deciding private claims under CPAs. It suggests that courts apply a commonsense construction to $\mathrm{CPAs}$ with indeterminate language and require fundamental elements of tort law. In cases where the language of the statutes lack the flexibility to allow such a construction, or where the judiciary chooses not to act, the Article suggests that state legislatures should intervene. For this purpose, the Article provides several principles that legislators should consider in amending CPAs.

\section{THE HiSTORIC FOUNDATION OF CONSUMER PROTECTION ACTS}

State consumer protection statutes have their origin in common law fraud and misrepresentation claims as well as in federal consumer protection law. Yet, when states adopted CPAs, they did not explicitly include many of the required elements of the common law actions in the statutes. They also failed to fully appreciate Congress's concerns with creating a private right of action for such a broad range of conduct. This combination has resulted in the abuse of CPAs today.

5. See California Secretary of State, Statement of Vote and Supplement to the Statement of Vote, 2004 Presidential General Election, Nov. 2, 2004, at 45 (2004), http://www.ss.ca.gov/elections/sov/2004_general/ssov/formatted_ballot_measures_detail.pdf.

6. CAL. Bus. \& PROF. CODE $\S \S 17200-17210$ (West $1997 \&$ Supp. 2005). 


\section{A. Consumer Protection Prior to the Twentieth Century}

What is known today as actionable misrepresentation or nondisclosure previously was known as the tort action of deceit. ${ }^{7}$ The present tort of misrepresentation evolved from the "Writ of Deceit," which dates back to the year $1201 .^{8}$ This Writ only applied to the use of a legal procedure to swindle another. ${ }^{9}$ Later, the tort developed to provide "a remedy for many wrongs which we should now regard as breaches of contract, such as false warranties in the sale of goods." 10 Here, tort law and contract law merged: courts generally limited the action to direct transactions between the plaintiff and the defendant. ${ }^{11}$

The common law further developed to recognize, in certain circumstances, claims for fraudulent misrepresentation or deceit, negligent or innocent misrepresentation, and concealment and nondisclosure. An action for fraudulent misrepresentation generally requires the plaintiff to show (1) the defendant knew its statement was false, inaccurate, or lacked basis in fact; (2) the defendant had an intent to deceive; (3) the misstatement was material, meaning that the absent information would have affected the plaintiff's decision to purchase the product; (4) the plaintiff relied upon the misrepresentation; (5) the reliance was objectively reasonable or justifiable; and (6) the reliance was a substantial factor in causing a monetary loss. ${ }^{12}$

The common law also developed to allow claims for negligent misrepresentation, which courts did not historically recognize under the law of deceit. Although scienter is not a required element of a negligent misrepresentation claim, a plaintiff must show either (1) that the defendant made a false statement because of a lack of reasonable care in ascertaining the facts or in the manner of expression or (2) absence of skill or competence expected in a given industry or profession. ${ }^{13}$ The

7. Dan B. Dobbs et al., Prosser \& Keeton on Torts $\S 105$, at 727 (5th ed. 1984) [hereinafter PROSSER \& KEETON ON TORTS].

8. Id.

9. Id. $\S 105$, at $727-28$.

10. Id. $\S 105$, at 728 .

11. Id. It was not until 1789 , as the notion of caveat emptor subsided, that the tort of deceit was first applied where the plaintiff had no dealings with the defendant but had been induced by a misrepresentation to extend credit to a third person. See id. (citing Pasley v. Freeman, (1789) 100 Eng. Rep. 450 (K.B.)).

12. See Restatement (SECOND) OF TORTS $\S \S 525-526,537-538,546,548,548$ A (1989); see also DAN B. DOBBS, THE LAW OF TORTS $\S \S 470,472,474$ (2000); PROSSER \& KEETON ON TORTS, supra note $7, \S \S 107-110$.

13. PROSSER \& KEETON ON TORTS, supra note 7, § 107. 
plaintiff must also show reasonable reliance, injury, causation, and damages. ${ }^{14}$ Today, nondisclosure may also be the basis for common law liability, such as when a special confidential or fiduciary relationship exists between the plaintiff and the defendant that justifies reliance based on trust or confidence. ${ }^{15}$

Although the strength of caveat emptor as a concept in American law had diminished by the beginning of the twentieth century, common law remedies remained inadequate to protect consumers in some situations. For instance, the law governing misrepresentation claims required that a person first suffer an injury before bringing a claim. The law did not allow for a proactive approach to stop obviously fraudulent practices before an individual was injured. It was particularly difficult for a plaintiff to show a defendant's intent to deceive - a required element of a fraud claim - and the relatively small damages in some cases did not warrant the expenses that accompanied a lawsuit. ${ }^{16}$ In many situations, breach of contract actions also were insufficient because a business could make false claims about its product or advertise lower-than-actual prices without entering into a contract. ${ }^{17}$

\section{B. Origin and Development of Federal Government Regulation and Enforcement}

The inadequacy of common law tools with which a consumer could address false advertising and deceitful commercial schemes in some circumstances eventually led Congress in 1914 to establish the Federal Trade Commission (FTC) and empower it to regulate such conduct. ${ }^{18}$ The FTC consisted, as it does today, of five members appointed by the President with the advice and consent of the Senate. ${ }^{19}$ Congress was concerned about the growth and spread of monopolies when it passed the FTC Act, so the Act initially charged the Commission with regulating

14. Id. $\S \S 108-110$.

15. Id. § 106; Victor E. Schwartz Et Al., Prosser, WADE \& SchWartZ's TorTs 1012-13 (10th ed. 2000) (citations omitted) [hereinafter PROSSER, WADE \& SCHWARTZ].

16. Jack E. Karns, State Regulation of Deceptive Trade Practices Under "Little FTC Acts": Should Federal Standards Control?, 94 DiCK. L. REV. 373, 374 (1990).

17. An individual bringing a consumer protection action as a breach of contract claim might also have to overcome defenses such as the statute of frauds, the parol evidence rule, and privity of contract requirements. See Jeff Sovern, Private Actions Under the Deceptive Trade Practices Acts: Reconsidering the FTC Act as Rule Model, 52 Oніо ST. L.J. 437, 451-52 (1991) (discussing these various defenses).

18. See Federal Trade Commission Act, Pub. L. No. 63-203, 38 Stat. 717 (1914) (codified as amended at 15 U.S.C. $\S \S 41-58(2000)$ ) (establishing the FTC).

19. See 15 U.S.C. $\S 41$ (setting the number and qualifications for FTC commissioners). 
"unfair methods of competition." 20 Thus, in the beginning, the Commission focused largely on antitrust and other trade regulation violations.

After the Supreme Court found that the FTC lacked power to regulate activities that had no effect on competition between businesses, such as false advertising, ${ }^{21}$ Congress amended the FTC Act to declare unlawful all "unfair or deceptive acts or practices in commerce," laying the foundation of federal consumer protection today. ${ }^{22}$ The Wheeler-Lea Act of 1938 provided the FTC with broad authority to prohibit unfair or deceptive acts. ${ }^{23}$ The Act itself provided little guidance as to which activities were "unfair or deceptive," because Congress recognized that "it would undertake an endless task" by attempting to provide an exhaustive list of prohibited practices. ${ }^{24}$ For this reason, Congress decided, by a "general declaration," to condemn unfair practices and "leave it to the commission to determine what practices were unfair." 25

20. $\S 5,38$ Stat. at 719 .

21. See FTC v. Raladam Co., 283 U.S. 643, 654 (1931) (holding that the FTC has no authority to issue a cease-and-desist order with regard to false advertising promoting an ineffective weightloss product where the advertising caused harm only to consumers); see also FTC v. R.F. Keppel \& Brother, Inc., 291 U.S. 304, 313 (1934) (suggesting that Congress should expand the power of the FTC to regulate unfair practices that exploit consumers); ANNUAL REPORT OF THE FEDERAL TRADE COMMISSION (1935), reprinted in 6 THE LEGISLATIVE HISTORY OF THE FEDERAL ANTITRUST LAWS AND RELATED STATUTES 4836-37 (Earl W. Kintner, ed., 1983) [hereinafter Kintner] (advocating for a statutory change).

22. Wheeler-Lea Act of 1938, Pub. L. No. 75-447, §3, 52 Stat. 111, 111 (1938) (codified as amended at 15 U.S.C. $\S 45($ a) (2000)). Today, more than half of the FTC's 1000-plus full-time employees focus on consumer protection. FTC, FISCAL YEAR 2006 CONGRESSIONAL JUSTIFICATION 13 (2005), available at http://www.ftc.gov/ftc/oed/fmo/budgetsummary06.pdf. The FTC aggressively uses its cease-and-desist power to protect America's consumers. Justin Dingfelder \& Sandra Brickels, To Protect Consumers, the FTC Means Business, 45 FED. LAW., Jan. 1998, at 24 25. In 2004, "the FTC brought 83 actions in federal district court to protect consumers against unfair and deceptive trade practices, and obtained 110 orders requiring the return of more than $\$ 380$ million in redress to consumers." FTC, FISCAL YEAR 2006 CONGRESSIONAL JUSTIFICATION, supra, at 1. "In the first quarter of ... 2005, the FTC brought 21 actions in federal district court to protect consumers and obtained 16 judgments ordering the return of nearly $\$ 160$ million in consumer redress." $I d$. at 5. "These cases attacked a wide range of fraud and deception, including bogus weight loss products, advance-fee credit card scams, business opportunity schemes, deceptive spam, fraudulent telemarketing, deceptive credit counseling services, deceptive and unfair debt collection practices, and violations of the Fair Credit Reporting Act (FCRA).” Id. The Commission's 2006 budget request was $\$ 211$ million, $\$ 119$ million of which was designated for consumer protection. Id. at 3. Funds budgeted for consumer protection have kept pace with inflation during the past three years, from $\$ 105$ million actual in fiscal year 2004, to $\$ 115$ million estimated in fiscal year 2005, to $\$ 119$ million proposed for fiscal year 2006. Id. at 20. The FTC's overall budget request for fiscal year 2006 represented a $\$ 6.7$ million increase over its 2005 budget. Id. at 1 .

23. See $\S 3,52$ Stat. at 111 .

24. H.R. REP. NO. 1142, at 19 (1914) (Conf. Rep.).

25. S. REP. NO. 597, at 13 (1914), reprinted in 5 Kintner, supra note 21, at 3909-10. 
The definitions of "unfair" and "deceptive" continue to evolve through administrative adjudications, case law, FTC rulemaking, and agency "guides." 26 The FTC, based on its understanding of public values, has broad discretion to determine when an act is unfair. ${ }^{27}$ The definition of an unfair act, as developed by the $\mathrm{FTC}^{28}$ and codified in the United States Code, is one that "causes or is likely to cause substantial injury to consumers which is not reasonably avoidable by consumers themselves and not outweighed by countervailing benefits to consumers or to competition." 29 Unfair acts or practices traditionally included coercive or high-pressure selling, withholding material information, unsubstantiated claims, and post-purchase rights and remedies. ${ }^{30}$ They

26. The FTC is authorized to promulgate general interpretive rules, as well as rules declaring particular practices to be "unfair or deceptive" where it believes such practices to be "prevalent." 15 U.S.C. $\S 57 \mathrm{a}$ (2000). The FTC has adopted regulations designating particular practices as unfair or deceptive, such as those involving home purchases, consumer credit contracts, and funeral industry practices. See, e.g., 16 C.F.R. $§ 429$ (2005) (providing a home purchaser with the right to cancel a contract within three business days); id. $\S 444$ (unfair credit practices); id. $\S 453$ (funeral industry practices). These rules target areas where consumers are particularly vulnerable or where there is a danger of coercion through high-pressure sales tactics. A violation of an FTC rule is considered a per se violation of the Act and may also be treated as such under state consumer protection laws. See David J. Federbush, The Unexplored Territory of Unfairness in Florida's Deceptive and Unfair Trade Practices Act, 73 FLA. B.J., May 1999, at 26, 32-33. The FTC has also issued informal "guides" on various practices such as deceptive pricing, advertising of warranties, use of the word "free," use of endorsements and testimonials, and fuel economy for new automobiles. See, e.g., Guides Against Deceptive Pricing, 16 C.F.R. $§ 233$ (2005); Guides for the Advertising of Warranties and Guarantees, id. $\S 239$; Guide Concerning Use of the Word "Free" and Similar Representations, id. $\S 251$; Guides for the Use of Endorsements and Testimonials in Advertising, id. $\S 255$. These guides do not have the same legal force as Commission rules.

27. See FTC v. Sperry \& Hutchinson Co., 405 U.S. 233, 244 (1972) ("[T]he [FTC] does not arrogate excessive power to itself if, in measuring a practice against the ... congressionally mandated standard of fairness, it . . considers public values beyond simply those enshrined in the letter or encompassed in the spirit of the antitrust laws."); see generally Stephen Calkins, FTC Unfairness: An Essay, 46 WAYNE L. REV. 1935 (2000) (discussing the development of the law of unfairness); Michael M. Greenfield, Unfairness Under Section 5 of the FTC Act and its Impact on State Law, 46 WAYNE L. REV. 1869 (2000) (same).

28. During the 1970 s, the FTC was particularly aggressive in attacking what it considered unfair practices, leading to calls for congressional intervention. See 6 Kintner, supra note 21, at 4938 (stating that during the 1970s the FTC aggressively attacked numerous practices that were neither anticompetitive nor outright deceptive). In 1980, in response to an announced congressional oversight hearing, the Commission issued a "Policy Statement on Unfairness." Letter from Michael Pertschule, Chairman, et al., to Sens. Wendell H. Ford \& John C. Danforth, FTC Policy Statement on Unfairness (Dec. 17, 1980) [hereinafter Unfairness Statement], available at http://www.ftc.gov/bcp/policystmt/ad-unfair.htm. This informal letter, signed by each of the five FTC Commissioners, was the basis of the definition codified by Congress in 1994. S. REP. NO. 103130, at 13 (1994), reprinted in 1994 U.S.C.C.A.N. 1776, 1787 ("This section [intends] to codify, as a statutory limitation on unfair acts or practices, the principles of the FTC's December 17, 1980, policy statement on unfairness, reaffirmed by a letter from the FTC dated March 5, 1982.").

29. See Federal Trade Commission Act Amendments of 1994, Pub. L. No. 103-312, § 9, 108 Stat. 1691, 1695 (1994) (codified at 15 U.S.C. $\S 45(n)$ ) (explaining when an act or practice can be declared unlawful on the ground that it is unfair). 
have evolved to include theft, breaking of other laws, using insufficient care, interfering with consumer rights, and advertising that promotes unsafe practices. ${ }^{31}$

The definition of a deceptive act has similarly developed over time. Historically, the test for deception was whether the act or practice had the tendency or capacity to deceive the general public. ${ }^{32}$ The "general public" was sometimes defined as "that vast multitude which includes the ignorant, [the] unthinking, and the credulous, who, in making purchases, do not stop to analyze but too often are governed by appearances and general impressions." 33 This changed in 1983 when the Commission issued a policy statement shifting away from a rather extreme and fatuous standard to a more moderate, "reasonable" consumer standard. ${ }^{34}$ Courts have adopted the reasoning of this "Deception Statement," 35 under which a practice or omission is deceptive if (1) it is likely to mislead consumers; (2) the consumer's interpretation of the representation is reasonable under the circumstances; and (3) the representation is "material" in that it is likely to affect either a consumer's choice of whether to purchase a product or the consumer's health or safety in its use. ${ }^{36}$ The potential impact of a representation is viewed from the perspective of the targeted group. ${ }^{37}$ For example, greater scrutiny is given to practices targeting those who are particularly

30. See Calkins, supra note 27, at 1961 (citing PETER C. WARD, FEDERAL TrAde COMMISSION: LAW, PRACTICE AND PROCEDURE ch. 5 (1999)).

31. Id. at 1962 .

32. Aspinall v. Philip Morris Cos., 813 N.E.2d 476, 487 (Mass. 2004) (citing FTC v. ColgatePalmolive Co., 380 U.S. 374, 391-92 (1965)). See Am. Home Prods. Corp. v. FTC, 695 F.2d 681, 687 (3d Cir. 1982) (supporting the FTC's finding that by implication and innuendo a deceptive impression had been created); Exposition Press, Inc. v. FTC, 295 F.2d 869, 872 (2d Cir. 1961) (finding advertisement deceptive because it had the "tendency and capacity to deceive a substantial portion of the purchasing public").

33. See Aspinall, 813 N.E.2d at 487 (quoting 1 Rudolf CALlman, UNFAIR COMPETITION AND TRADE-MARKS $§ 19.2(\mathrm{a})(1)$, at 341-44 (2d ed. 1950)); see also Geismar v. Abraham \& Strauss, 439 N.Y.S.2d 1005, 1007 (N.Y. Sup. Ct. 1981) (stating that New York's deceptive advertising and unfair trade practices laws "were enacted to safeguard the "vast multitude which includes the ignorant, the unthinking and the credulous.' ... The test is not whether the average man would be deceived.") (quoting Floersheim v. Weinburger, 346 F. Supp. 950, 957 (D.D.C. 1972)).

34. Letter from James C. Miller III, Chairman, to Rep. John D. Dingell, Chairman of House Comm'n on Energy \& Commerce, FTC Policy Statement on Deception (Oct. 14, 1983) [hereinafter Deception Statement], available at http://www.ftc.gov/bcp/policystmt/ad-decept.htm.

35. Only the Chairman of the Commission, James C. Miller III, signed the FTC's 1983 Deception Statement. See id. A split Commission adopted the policy statement in Cliffdale Assocs., Inc., 103 F.T.C. 110, 184 (1984), and federal courts have applied it since that time. See, e.g., FTC v. Pantron I Corp., 33 F.3d 1088, 1095 (9th Cir. 1994); Kraft, Inc. v. FTC, 970 F.2d 311, 314 (7th Cir. 1992); Sw. Sunsites, Inc. v. FTC, 785 F.2d 1431, 1436 (9th Cir. 1986).

36. Deception Statement, supra note 34.

37. Id. 
susceptible to exaggerated claims, such as elderly people or children. ${ }^{38}$ Practices and representations directed to a sophisticated or well-educated audience, such as physicians, are judged in light of the expected knowledge of that group. ${ }^{39}$

\section{Why Congress Placed Enforcement Solely With the Government and Not With Private Lawyers Under the FTC Act}

Even prior to the 1938 amendments, the Supreme Court observed that the meaning and application of unfairness "belongs to that class of phrases which do not admit of precise definition," but are arrived at as a result of "the gradual process of judicial inclusion and exclusion." 40 Members of Congress extensively debated the definition of "unfair" during consideration of the 1914 Act, and many were concerned that such a broad provision - without clarification-was an unconstitutional delegation of legislative power, which would allow for arbitrary or abusive enforcement. ${ }^{41}$

One significant factor in calming the concerns of Congress was that the power to determine unfair practices would be placed in a nonpartisan Commission, composed of "a body of five men, intelligent men, ... [including] lawyers, economists, publicists, and men experienced in industry, who will . . . be able to determine justly whether the practice is contrary to good morals or not." 42 An additional factor ameliorating Congress's concern at the time of the 1938 expansion of the Act to include consumer protection was that the FTC's power was "merely preventative and cooperative rather than penal."43 The FTC Act's remedies continue to be primarily injunctive in nature and the Commission generally acts through instituting an administrative proceeding or an action in federal court seeking an order that the respondent "cease and desist from the violation of the law so charged." 44 The FTC may seek equitable relief including a preliminary or permanent

\footnotetext{
38. $I d$.

39. Id.

40. FTC v. Raladam Co., 283 U.S. 643, 648 (1931), superseded by statute, Wheeler-Lea Act of 1938, Pub. L. No. 75-447, 52 Stat. 111 (1938), as recognized in Simeon Mgmt. Corp. v. FTC, 579 F.2d 1137, 1146 (9th Cir. 1978).

41. See, e.g., 51 CONG. REC. 11,084-109, 11,112-16 (1914).

42. Id. at 11,108-09 (statement of Sen. Newlands). Senator Newlands continued, "I would rather have the opinion of such a commission upon a question of good morals in business than to have the opinion of the court upon such a question." Id.

43. S. REP. NO. 74-2, at 1 (1936).

44. 15 U.S.C. $\S \S 45(b), 53(b)$ (2000).
} 
injunction, freezing of assets, and corrective advertising. ${ }^{45}$ The Commission also has authority to seek restitution for injured consumers and may impose substantial fines for violation of its orders. ${ }^{46}$ In addition, the Commission's broad authority to bring actions for violations of the Act is tempered by budgetary and staffing restraints and a requirement that the Commission pursue actions only when they significantly further the public interest. ${ }^{4}$

Through these means, enforcement was placed solely with the government, not with private lawyers. In fact, a private right of action was considered and rejected when Congress considered the FTC Act in 1914. At that time, Senator Clapp of Minnesota proposed an amendment that provided as follows:

[A]ny person who shall be injured in his business or property by any other person or corporation by reason of anything forbidden or declared to be unlawful by this act may sue therefore in any district court of the United States in the district in which the defendant resides or may be found, without respect to the amount in controversy, and shall recover threefold the damages by him sustained and the costs of the suit, together with a reasonable attorney's fee. ${ }^{48}$

45. See id. §57b(b).

46. In 1975, Congress expanded the FTC's authority to permit the Commission to seek restitution to those injured by a company's deceptive acts through a civil action in court. See Magnuson-Moss Warranty-Federal Trade Commission Improvement Act of 1975, Pub. L. No. $93-$ $637, \S 19,88$ Stat. 2201, 2201-02 (1975) (codified as amended at 15 U.S.C. $\S 57 \mathrm{~b}(2000)$ ). In some cases, a court may order a company to pay consumers substantial sums. See Peter C. Ward, Restitution for Consumers Under the Federal Trade Commission Act: Good Intentions of Congressional Intentions?, 41 AM. U. L. REV. 1139, 1140 (1992) (discussing a federal case where the court awarded restitution in the amount of $\$ 1.96$ million against a retail art business that engaged in deceptive sales practices). More often, when faced with an FTC action, a company may opt to settle with the Commission. If a business fails to abide by an order of the Commission or federal court, the FTC can institute a punitive action and seek fines of up to $\$ 10,000$ per violation. See 15 U.S.C. $\S 45(1)$ (2000) (capping fines at $\$ 10,000)$. The amount of the civil fine is generally based on "the good or bad faith of the respondent; the injury to the public; the respondent's ability to pay; the desire to eliminate the benefits derived by a violation; and the necessity of vindicating the FTC's authority." Dingfelder \& Brickels, supra note 22, at 26 (citing United States v. Reader's Digest Ass'n, Inc., 494 F. Supp. 770, 772 (D. Del. 1980), aff'd, 662 F.2d 955 (3d Cir. 1981)). These civil penalties can easily escalate into the millions of dollars because each day of violating an FTC order is considered a separate offense. See id. at 27 (discussing a $\$ 2.4$ million penalty paid by General Nutrition, Inc., regarding claims made for vitamin supplements; a $\$ 2.75$ million penalty against a manufacturer for claims made in advertising its "Miracle Ear" hearing aids; and a \$1.5 million penalty against a manufacturer of skin care products for unsubstantiated claims regarding a baldness treatment, a wrinkle lotion, and a burn cream). In some circumstances, the FTC may seek criminal penalties for advertising that is intentionally deceptive and dangerous to the public's health. See 15 U.S.C. § 54(a) (2000).

47. See 15 U.S.C. $\S 53$ (b) (2000) (requiring the Commission to find that bringing an action in federal court to enjoin a violation of the FTC Act is in the public interest).

48. See 51 CONG. REC. 13,113 (1914). 
Senator Clapp viewed this amendment, modeled after the Sherman antitrust law, as "putting [a] remedy in the hands of the aggrieved party" and providing "a very strong incentive to the observance of and obedience to the law by those against whom the law is directed as a regulating and controlling force." 49

The proposed amendment was opposed on a number of grounds. The first was a question of interpretation. Congress feared courts might allow consumers to go directly to court without prior FTC action, which would have allowed judges rather than commissioners to decide whether conduct was fair. ${ }^{50}$ Even if courts construed the Act to require a FTC ruling that conduct was unlawful before consumers could bring a private right of action, the concerns of some were not relieved. As one member noted, "[I]f no man on earth can know whether he is disobeying the law or not until some time in the future, when some commission finds out and tells him that he is disobeying the law, does not the Senator think that mulcting him in treble damages is a little bit harsh?" ${ }^{51}$ In addition, some members of Congress thought opening two forums for deciding violations under the Act, the Commission and federal courts, could lead to confusion and conflict. ${ }^{52}$

Other members opposed the amendment's provision of treble damages. ${ }^{53}$ For example, restraint of trade or monopoly under the Sherman antitrust law, upon which the amendment was modeled, was a criminal act subject to stiff penalties, and thus treble damages in that situation may have been appropriate. ${ }^{54}$ The FTC Act, however, is unlike other laws providing for treble damages, which ordinarily involve a criminal act or, at the very least, "a high degree of moral turpitude ... the same [in] character as punitive or exemplary damages." ${ }^{, 55}$ It was also noted that such a provision could lead corporations to vigorously fight

\footnotetext{
49. Id.

50. See id. at 13,114-15 (colloquy between Sens. McCumber and Clapp); id. at 13,115 (colloquy between Sens. Brandegee and Clapp).

51. See id. at 13,114 (statement of Sen. McCumber). Senator McCumber continued, "[I]f this amendment is incorporated in the bill, you immediately provide for the punishment of an offense of which the offender can know nothing, at least until some quasi legislative body has passed judgment upon the question whether or not he has a right to do a particular thing." Id. See also id. at 13,118 (statement of Sen. Williams) ("It looks to me as if this provision might be retroactive in a rather oppressive manner.").

52. See id. at 13,120 (statements of Sens. Stone and Reed).

53. See id. at 13,115-16 (statement of Sen. Newlands).

54. See id. at 13,116-17 (statement of Sen. Walsh).

55. Id. at 13,116 (statement of Sen. Walsh).
} 
FTC rulings in court "to the bitter end," rather than immediately abandon the practice. ${ }^{56}$

Some members of Congress believed that citizens injured by an unfair act could already exercise their rights at common law to bring an action for recovery. ${ }^{57}$ In addition, members of Congress expressed concern that "a certain class of lawyers, especially in large communities, will arise to ply the vocation of hunting up and working up such suits," particularly given a broad right of action for "unfair" conduct. ${ }^{58}$ Members feared that "[t]he number of these suits... no man can estimate." 59 What makes this legislative history so interesting today is that many members of Congress foretold the very problems that would arise when legislators added private causes of action to state CPAs.

After further consideration, Senator Clapp revised his proposed amendment to clarify that a private right of action would only exist after the Commission had declared the conduct unlawful. ${ }^{60}$ Nevertheless, the Senate decisively rejected the proposed amendment by a forty-one to eighteen bipartisan vote. ${ }^{61}$ Although Congress significantly expanded the reach of the FTC Act in passing the Wheeler-Lea Act of $1938^{62}$ and later strengthened FTC-enforcement mechanisms, expanded redress, and increased civil penalties with the Magnuson-Moss Warranty-Federal Trade Commission Improvement Act of $1975,{ }^{63}$ in the FTC Act's ninety years of existence, Congress has chosen not to amend it to recognize a private right of action.

The federal judiciary upheld congressional intent and expressed similar concern over the potential for abuse when it rejected in 1973 a request that it find an implied private right of action under the FTC Act. ${ }^{64}$ The United States Court of Appeals for the District of Columbia Circuit

56. See id. at 13,115-16 (statements of Sens. Brandegee and Newlands).

57. See, e.g., id. at 11,112 (statement of Sen. Newlands) ("[P]roceedings under this act will not, of course, interfere with the private right of any man who is injured by a competitor by practices such as have been referred to bring a suit either at law or in equity for enforcement of his rights."). One Senator suggested that findings of the Commission might be introduced as prima facie evidence of unlawful conduct in a civil suit. See id. at 13,151 (statement of Sen. Cummins).

58. Id. at 13,120 (statement of Sen. Stone).

59. Id.

60. Id. at 13,143 .

61. Id. at 13,149. See also id. at 13,150 (colloquy between Sens. Cummins and Clapp debating need for private remedy in addition to public enforcement); Ward, supra note 46, at 1150-51.

62. See supra notes 21-24 and accompanying text.

63. See supra note 46.

64. See Holloway v. Bristol-Myers Corp., 485 F.2d 986, 986 (D.C. Cir. 1973) ("Private enforcement of the Federal Trade Commission Act would pose serious problems to the enforcement activities of the FTC, and is inconsistent with the legislative scheme established by Congress."). 
found that a private remedy would over penalize companies that had committed practices not considered unfair, deceptive, or misleading prior to their commission. ${ }^{65}$ In rejecting a private right of action, the court also noted that the FTC was composed of a body of experts and economists who could create policy in a reasoned, orderly, and forward-looking fashion. ${ }^{66}$ The court found that private lawsuits, on the other hand, created policy in a piecemeal and retroactive manner. ${ }^{67}$

This Article does not advocate for the elimination of private rights of action under CPAs. Nonetheless, all of these concerns ring true as we consider how private rights of action should be interpreted under state CPAs.

\section{STATES AdOPT CONSUMER PROTECTION LEGISLATION}

During the 1960s and 1970s, many states adopted their own CPAs, ${ }^{68}$ often referred to as "little-FTC Acts." 69 Most little-FTC Acts were based on alternative forms suggested by the $\mathrm{FTC}^{70}$ or model state legislation developed by the National Conference of Commissioners on Uniform State Laws. ${ }^{71}$ Although these laws take various forms, each broadly prohibits unfair or deceptive acts, as does the FTCA Act. ${ }^{72}$ Most state statutes also include a nonexclusive-but sometimes extensive-list of prohibited practices. ${ }^{73}$ The crucial difference, however, is that almost all

65. See id. at 998 (stating that the advantage of the FTC acting in an advisory capacity to those in compliance with the Act would be endangered).

66. Id. at $998-99$.

67. Id. at $997-98$.

68. J.R. Franke \& D.A. Ballam, New Applications of Consumer Protection Law: Judicial Activism or Legislative Directive?, 32 SANTA ClARA L. REv. 347, 357 (1992).

69. See id. at 347 n.1 (citing Karns, supra note 16).

70. See Council of State Governments, Suggested State Legislation: Unfair Trade Practices and Consumer Protection Law, at C4-C5 (1969); see generally William A. Lovett, Private Actions for Deceptive Trade Practices, 23 ADMIN. L. REV. 271, 275 (1971).

71. Uniform Deceptive Trade Practices Act (amended 1966), 7A U.L.A. 139 (2002).

72. See, e.g., Alaska StAT. $§ 45.50 .471$ (2004); Ky. Rev. Stat. AnN. $\$ 367.170$ (LexisNexis 1996); LA. REV. STAT. ANN. § 51:1409 (2003); MASS. GeN. LAWS ANN. ch. 93A, § 2(a) (West 2004); Мich. COMP. LaWs ANN. § 445.903 (West 2002); Miss. Code ANN. § 75-24-5(1) (West 1999); MonT. CODE ANN. § 30-14-103 (2003); N.C. Gen. StAT. § 75-1.1(a) (2003); Or. REV. STAT. $\S 646.608(1)(\mathrm{u})$ (2003). The District of Columbia's statute, however, does not explicitly recognize a violation of the act for "unfair" trade practices, and courts have not permitted such actions. See D.C. CODE ANN. § 28-3904 (LexisNexis 2001); Atwater v. D.C. Dep't of Consumer \& Regulator Affairs, 566 A.2d 462, 465 (D.C. 1989).

73. See, e.g., Alaska Stat. AnN. § 45.50.471(b); ARK. Code AnN. §§ 4-88-107(a), -109 (Supp. 2003); COLO. Rev. STAT. § 6-1-105(1)(a)-(ww) (2004); D.C. CODE ANN. § 28-3904(a)-(ee); Ga. Code ANN. § 10-1-393.1 (2000); IdAHO CODE ANN. § 48-603 (2003); IOWA CODE ANN. § 714.16(2)(b)-(n) (West 2003); MinN. STAT. ANN. § 325D.44(1) (West 2004); Miss. CodE ANN. § 75-24-5(2); OHIO Rev. Code ANN. § 1345.02(B) (LexisNexis 2002); OKLA. STAT. AnN. tit. 15, § 
state CPAs provide consumers with a private right of action to enforce their provisions.

The federal and state laws were meant to complement each other. ${ }^{74}$ In the "heyday of consumerism," the FTC urged states to adopt their own little-FTC Acts as a way of combining resources to target unfair and deceptive practices at both the local and national levels. ${ }^{75}$ Most state laws include a provision directing state regulators to look to the FTC for guidance in terms of substantive law, encouraging state regulators to emphasize enforcement and remedies, rather than focus on policymaking. ${ }^{76}$ All fifty states and the District of Columbia now have adopted little-FTC Acts. ${ }^{7}$

Unlike the FTC Act, which provides for enforcement only by state agencies, nearly every state CPA provides consumers with a private right of action in addition to government enforcement. ${ }^{78}$ Only Iowa relies exclusively on its Attorney General to enforce its consumer protection law in court. ${ }^{79}$ Although the little-FTC Acts of Arizona and Delaware do not explicitly provide for a private right of action, courts in those states have found that citizens have an implied right to bring lawsuits for violations of the statutes. ${ }^{80}$

753 (West 1993); OR. Rev. Stat. § 646.608(1); TeX. Bus. \& COM. CODE ANN. § 17.46(b) (Vernon 2002) (amended by H.R. 2018, 78th Leg. ch. 728 Tex.); W. VA. CODE ANN. § 46A-6-102 (LexisNexis 1999). States may also have numerous other consumer protection statutes addressing particular practices.

74. See Vt. Stat. AnN. tit. 9, § 2451 (2004) (recognizing that the purpose of the Vermont Consumer Fraud Act is to "complement the enforcement of federal statutes and decisions governing unfair methods of competition and unfair and deceptive acts or practices in order to protect the public, and to encourage fair and honest competition"); W. VA. CODE ANN. § 46A-6-101(1) (same).

75. Franke \& Ballam, supra note 68 , at $356-57$.

76. Id.

77. See Karns, supra note 16, at 373-74 n.2 (citing state statutes).

78. See Sovern, supra note 17, at 448-52 (describing the opportunities states provide to consumers). In several states, legislatures first enacted laws providing only for state attorney general enforcement but later added a private right of action. For example, New Jersey enacted its Consumer Fraud Act in 1960 " "to permit the Attorney General to combat the increasingly widespread practice of defrauding the consumer." Cox v. Sears Roebuck \& Co., 647 A.2d 454, 460 (N.J. 1994) (quoting Senate Committee, Statement to Senate Bill No. 199 (1960)). The New Jersey law was amended to provide for citizen lawsuits in 1971. See N.J. STAT. AnN. § 56:8-19 (West 2001). See also N.Y. Gen. Bus. LAW $\S 349$ (h) (McKinney 2004) (amended 1980); 73 Pa. Stat. ANN. § 201-9.2 (West Supp. 2005) (amended 1976); WASH. REV. CODE ANN. § 19.86.010 (West 1999) (amended 1970).

79. See Molo Oil Co. v. River City Ford Truck Sales, Inc., 578 N.W.2d 222, 227-28 (Iowa 1998).

80. See Sellinger v. Freeway Mobile Home Sales, Inc., 521 P.2d 1119, 1122 (Ariz. 1974); Young v. Joyce, 351 A.2d 857, 859 (Del. 1975). In fact, for the first seven years of its existence, it was believed that only the state Attorney General could bring actions under Arizona's CPA. See Edwin M. Gaines, Jr., Arizona's Consumer Fraud Act: A Standard of Conduct, 22 ARIZ. L. Rev. 321,323 (1980). 


\section{A. Elements Necessary to Bring a Private Claim}

The elements necessary to bring private lawsuits under little-FTC Acts vary from state to state. In some cases, the required elements of a claim are explicitly stated in the legislation. In many other cases, the requirements for bringing a private lawsuit are based on the judiciary's interpretation of the law. The great variation in the interpretation of CPAs is significant for two reasons. First, it demonstrates the clear choices courts often have when applying CPAs. Second, the vast differences in the application of state laws makes it particularly inappropriate for courts to certify multi-state class actions alleging CPA claims or to apply the CPA of one state to conduct that occurred in another state.

Even the very definition of a prohibited act varies from state to state. In Washington, a practice is unfair if it "'offends public policy as ... [expressed] by statutes,... [or] is immoral, unethical, oppressive or unscrupulous; ... [and] causes substantial injury to consumers." ${ }^{\prime 81}$ It is deceptive if it has the potential "to deceive a substantial portion of the public." 82 Texas law limits the definition of "false, misleading, or deceptive" to specific, enumerated acts in private rights of action but does not apply this limitation in enforcement actions brought by its Attorney General. ${ }^{83}$ This assures that businesses have notice of prohibited conduct before being sued for damages. A handful of states require consumers to attempt to settle with the company or exhaust administrative procedures before instituting a lawsuit. ${ }^{84}$ Many state laws provide that the state is to interpret its law consistent with that of the FTC or look to the FTC for guidance in deciding prohibited practices. ${ }^{85}$

81. Blake v. Fed. Way Cycle Ctr., 698 P.2d 578, 583 (Wash. 1985) (quoting FTC v. Sperry \& Hutchinson Co., 405 U.S. 233, 244 n.5 (1972)).

82. Hangman Ridge Training Stables, Inc. v. Safeco Title Ins. Co., 719 P.2d 531, 535 (Wash. 1986) (en banc). See also 73 PA. STAT. ANN. § 201-2(4)(xxi) (West Supp. 2005) (prohibiting "engaging in any other fraudulent or deceptive conduct which creates a likelihood of confusion or of misunderstanding").

83. See Tex. Bus. \& Com. Code AnN. § 17.46(d) (Vernon 2002).

84. See, e.g., GA. CODE ANN. § 10-1-399(b) (2000) (requiring a claimant to deliver a written demand for relief identifying the claimant and reasonably describing the unfair or deceptive act or practice relied upon and the injury suffered to any prospective respondent at least thirty days prior to the filing of a private action); IND. CODE ANN. § 24-5-0.5-5(a) (LexisNexis 1996) (requiring the consumer to give notice to the supplier the sooner of six months after initial discovery of the deceptive act, one year following the transaction, or within thirty days of any time limitation with respect to a warranty); MISS. CODE ANN. § 75-24-15(2) (2000) (requiring consumers to make "a reasonable attempt to resolve any claim through an informal dispute settlement program approved by the Attorney General").

85. See, e.g., Mont. Code AnN. § 30-14-104 (2003); TEnN. CodE AnN. § 47-18-115 (2001); 
The most significant difference between state laws, however, is how they are applied in private lawsuits when issues of reliance, intent, and damages arise.

\section{The Need to Show Reliance}

Only a few states, such as Indiana, Texas, and Wyoming, explicitly require a showing of actual reliance in the text of the statute. ${ }^{86}$ Courts in a number of other states have ruled that CPA laws require private litigants to show that they relied on the alleged unfair or deceptive act and that this reliance was "reasonable" or "justifiable." 87 Similarly, Kansas courts have interpreted the statutory requirement that a person bringing a private lawsuit under the act be "aggrieved" to require a showing of reliance. ${ }^{88}$ In addition, courts in some states, such as Arizona, require a showing of actual reliance but do not necessarily require the reliance to be "reasonable." 89 Minnesota and North Dakota require a showing that the defendant intended that consumers rely on the alleged deceptive act, even if no one was actually misled. ${ }^{90}$

Vt. Stat AnN. tit. 9, § 2453(b) (Supp. 2004); W. VA. Code AnN. § 46A-6-101(1) (LexisNexis 1999).

86. IND. CODE ANN. § 24-5-0.5-4(a) (requiring reliance "upon an uncured or incurable deceptive act"); TEX. BuS. \& COM. CODE ANN. § 17.50(a)(1)(B) (Vernon Supp. 2005) (requiring that the deceptive act or practice be "relied on by a consumer to the consumer's detriment"); WYO. STAT. ANN. § 40-12-108(a) (2005) ("A person relying upon an uncured unlawful deceptive trade practice may bring an action under this act for the damages he has actually suffered as a consumer as a result of such unlawful deceptive trade practice."); see also VT. STAT. ANN. tit. 9, § 2461(b) (1993) (providing a private right of action to "[a]ny consumer who contracts for goods or services in reliance upon false or fraudulent representations or practices prohibited by ... [the act] ... or who sustains damages or injury as a result of any false or fraudulent representations or practices prohibited by [the act]").

87. See, e.g., Lynas v. Williams, 454 S.E.2d 570, 574 (Ga. Ct. App. 1995) (finding that "justifiable reliance" is an essential element of a claim under Georgia's Fair Business Practices Act); Philip Morris, Inc., v. Angeletti, 752 A.2d 200, 234-39 (Md. 2000) (denying class certification while noting that action under consumer protection statutes would require a showing of individual reliance); Weinberg v. Sun Co., 777 A.2d 442, 445-46 (Pa. 2001) (holding that because Pennsylvania's Unfair Trade Practices and Consumer Protection Law is rooted in fraud prevention, it is likely the legislature intended to retain the common law elements of fraud, including reliance); see also Tim Torres Enters. v. Linscott, 416 N.W.2d 670, 675 (Wis. Ct. App. 1987) (noting with approval the trial court's instruction that "there must be some actual consumer reliance ... before awarding pecuniary damages").

88. See Finstad v. Washburn Univ., 845 P.2d 685, 691-92 (Kan. 1993).

89. See, e.g., Parks v. Macro-dynamics, Inc., 591 P.2d 1005, 1008 (Ariz. Ct. App. 1979); Peery v. Hansen, 585 P.2d 574, 577-78 (Ariz. Ct. App. 1978) .

90. See N.D. Cent. CODE § 51-15-02 (1999); LeSage v. Norwest Bank Calhoun-Isles, 409 N.W.2d 536, 539-41 (Minn. Ct. App. 1987). 
Courts in most other jurisdictions do not require a showing of reliance. ${ }^{91}$ Often, these courts use in private lawsuits a standard similar to the test under the FTC Act: whether the act has the tendency or capacity to mislead consumers, regardless of whether the plaintiff actually and reasonably relied on the misrepresentation. ${ }^{92}$ Many state courts have ruled that their CPAs do not require private litigants to show they relied upon the alleged unfair or deceptive practice but do require plaintiffs to show the injury or loss had a causal connection to a violation of the act. ${ }^{93}$ Some do not require a plaintiff to plead actual reliance as a separate element of a CPA claim but consider reliance intricately interwoven with the requirement that a plaintiff demonstrate proximate cause. $^{94}$ In at least three states, it remains unclear whether reliance is required to bring a private lawsuit under their respective little-FTC Acts. ${ }^{95}$

91. See, e.g., Att'y Gen. v. Wyndham Int'l, Inc., 869 So. 2d 592, 598 (Fla. Dist. Ct. App. 2004) ("When addressing a deceptive or unfair trade practice claim, the issue is not whether the plaintiff actually relied on the alleged practice, but whether the practice was likely to deceive a consumer acting reasonably in the same circumstances.... [U]nlike fraud, a party asserting a deceptive trade practice claim need not show actual reliance on the representation or omission at issue." (citing Davis v. Powertel, Inc., 776 So. 2d 971, 973-74 (Fla. Dist. Ct. App. 2000))).

92. See, e.g., Alicke v. MCI Commc'ns Corp., 111 F.3d 909, 912 (D.C. Cir. 1997); Smoot v. Physicians Life Ins. Co., 87 P.3d 545, 550 (N.M. Ct. App. 2003); Forbes v. Par Ten Group, Inc., 394 S.E.2d 643, 650 (N.C. Ct. App. 1990); Richards v. Beechmont Volvo, 711 N.E.2d 1088, 1090 (Ohio Ct. App. 1998); Peabody v. P.J.'s Auto Village, Inc., 569 A.2d 460, 462 (Vt. 1989); see also PNR, Inc. v. Beacon Prop. Mgmt, 842 So. 2d 773, 777 (Fla. 2003) (finding that a showing of reliance is not required but that the plaintiff must show that a consumer acting reasonably under the circumstances would have been misled); Sw. Starving Artists Group, Inc. v. State ex rel. Summer, 364 So. 2d 1128, 1130 (Miss. 1978) (requiring a showing that the plaintiff would have acted differently had he or she known the actual facts); Blue Cross, Inc. v. Corcoran, 558 N.Y.S.2d 404, 405 (N.Y. App. Div. 1990) (finding that a showing of reliance is not required but that the plaintiff must show that a consumer acting reasonably under the circumstances would have been misled).

93. See Haesche v. Kissner, 640 A.2d 89, $93-94$ (Conn. 1994); Morris v. Osmose Wood Preserving, 667 A.2d 624, 634 (Md. 1995); Gennari v. Weichert Co. Realtors, 691 A.2d 350, 366-67 (N.J. 1977).

94. See, e.g., Oliveira v. Amoco Oil Co., 776 N.E.2d 151, 161-63 (Ill. 2002) (finding that proximate causation requires a plaintiff to show that he or she was actually deceived and recognizing that in the common law tort of fraudulent misrepresentation "cause-in-fact is defined as reliance").

95. For example, courts have split on the need to show reliance under Missouri and North Carolina law. Compare Fielder v. Credit Acceptance Corp., 98 F. Supp. 2d 1104, 1107 (W.D. Mo. 2000) (requiring a plaintiff to prove the elements of common law fraud), and Tucker v. Boulevard at Piper Glen LLC, 564 S.E.2d 248, 251 (N.C. Ct. App. 2002) (requiring a showing of actual reliance), with State ex rel. Webster v. Areaco Inv. Co., 756 S.W.2d 633, 635 (Mo. Ct. App. 1988) (not requiring elements of common law fraud), and Cullen v. Valley Forge Life Ins. Co., 589 S.E.2d 423 , 431 (N.C. Ct. App. 2003) (holding proof of reliance is not required), reh'g denied, 598 S.E.2d 138 (N.C. 2004). Vermont courts have not ruled on whether the state's CPA requires a showing of reliance in a private lawsuit. See Lalande Air \& Water Corp. v. Pratt, 795 A.2d 1233, 1235 (Vt. 2002). 


\section{The Requisite Intent}

CPAs often do not address the intent necessary, if any, to violate state law. Several courts have found that the CPA plaintiff does not need to show any intent on the part of the defendant. ${ }^{96}$

An equal or greater number of states require that the defendant act with some type of intent. A few state statutes require defendants to act willfully, knowingly, or intentionally. ${ }^{97}$ For example, a business violates South Dakota's Deceptive Trade Practices and Consumer Protection statute only when it knowingly and intentionally commits a deceptive act or practice, regardless of whether a person is actually misled. ${ }^{98}$ Courts interpreting Kansas, Michigan, and Virginia law have also found that the respective CPAs require that the defendant intended to deceive consumers. ${ }^{99}$ On the other hand, the Illinois Supreme Court has found, and the Delaware, Minnesota, and North Dakota statutes provide, that the defendant must have intended that consumers rely on its action, whether or not it intended to deceive them. ${ }^{100}$ Finally, some state courts have required a degree of intent in cases where a business is alleged to have omitted or concealed material facts but not in cases involving affirmative misrepresentations. ${ }^{101}$

96. See, e.g., Jacobs v. Healey Ford-Subaru, Inc., 652 A.2d 496, 506 (Conn. 1995); Brady v. Publishers Clearing House, 787 A.2d 111, 116 (Del. Ch. 2001); Regency Nissan, Inc. v. Taylor, 391 S.E.2d 467, 470 (Ga. Ct. App. 1990); Gennari v. Weichert Co. Realtors, 691 A.2d 350, 365 (N.J. 1977); Marshall v. Miller, 276 S.E.2d 397, 400-02 (N.C. 1981); D\&K Roofing, Inc. v. Pleso, 601 N.E.2d 561, 563 (Ohio Ct. App. 1991); see also Smith v. Scott Lewis Chevrolet, Inc., 843 S.W.2d 9, 12 (Tenn. Ct. App. 1992) (finding no showing of intent is necessary to recover, except knowledge or willfulness is required to recover treble damages); Winton v. Johnson Dix Fuel Corp., 515 A.2d 371, 376 (Vt. 1986) (finding the Vermont Consumer Fraud Act "does not require a showing of intent to mislead, but only an intent to publish the statement challenged"); McRae v. Bolstad, 676 P.2d 496, 500 (Wash. 1984) ("[P]roof of intent to deceive or defraud is not necessary if the action "has the capacity to deceive a substantial portion of the purchasing public." (quoting Haner v. Quincy Farm Chems., Inc., 649 P.2d 828, 831 (Wash. 1982))).

97. See OR. REv. STAT. $\S \S 646.605(10)$ ), -638(1) (2003) (willfully); S.D. CodIFIEd LAws $\S 37-$ 24-6(1) (2004) (knowingly and intentionally); UTAH CODE ANN. § 13-11-4(2) (2001) (knowingly or intentionally); WYO. STAT. ANN. § 40-12-105(a) (2005) (knowingly).

98. S.D. CODIFIED LAWS § 37-24-6(1).

99. See, e.g., Gill v. Rollins Protective Servs. Co., 773 F.2d 592, 598 (4th Cir. 1986) (interpreting Virginia law); Porras v. Bell, 857 P.2d 676, 678 (Kan. Ct. App. 1993); Dix v. Am. Bankers Assurance Co., 415 N.W.2d 206, 209 (Mich. 1987); see also Rizzo v. Michener, 584 A.2d 973, 980 (Pa. Super. Ct. 1990) (ruling that an action under the state's little-FTC Act requires satisfaction of the common law elements of fraud, including scienter).

100. Del. Code AnN. tit. 6, § 2513 (1999); MinN. Stat. ANN. § 325F.69 (West 2004); N.D. CENT. Code § 51-15-02 (1999); Connick v. Suzuki Motor Co., 675 N.E.2d 584, 593 (Ill. 1996); Siegel v. Levy Org. Dev. Co., 607 N.E.2d 194, 198 (Ill. 1992). See also W. VA. CodE ANN. § 46A6-102(f) (LexisNexis 1999) (requiring intent that others rely in some actions).

101. In Alaska, if a lawsuit is based on concealing a material fact, a defendant must have acted knowingly. ALASKA StAT. § 45.50.471(12) (2004). Similarly, in Arizona and Delaware, CPA 


\section{The Need to Show Injury In Fact and Damages}

Most courts require some showing of an injury, however small. For example, some statutes require a plaintiff to show an "ascertainable loss," which courts have found to provide a very low threshold for plaintiffs to cross. ${ }^{102}$ Several state laws appear to allow citizens to bring lawsuits under CPAs on behalf of the general public whether or not anyone has actually been harmed, ${ }^{103}$ and others simply provide that "any person" may bring a private lawsuit for a violation of the act. ${ }^{104}$ This opens the door for courts to allow plaintiffs who have never been harmed to sue and recover at least statutory damages.

After years of substantial abuse of its Unfair Competition Law, California voters recently amended their CPA to require those bringing private actions to show they had suffered an injury. ${ }^{105}$ On the other hand, the District of Columbia amended its statute in October 2000 to include a similar citizen suit provision authorizing a plaintiff to bring a claim on behalf of "itself, its members, or the general public" for a violation of the law of the District of Columbia. ${ }^{106}$ One federal court noted that this amendment might eliminate the requirements of injury in fact and causation. ${ }^{107}$ Another court recently found that, despite the amendment, a plaintiff must still show injury in fact and causation to have standing to bring a suit under the statute. ${ }^{108}$

claimants must show that the defendant intended that consumers rely on an omission of material fact. ARiz. Rev. Stat. AnN. § 44-1522(A) (2003); Stephenson v. Capano Dev., Inc., 462 A.2d 1069, 1074 (Del. 1983).

102. See, e.g., Hinchliffe v. Am. Motors Corp., 440 A.2d 810, 813-14 (Conn. 1981) (finding that consumers can meet the "ascertainable loss," requirement of the statute without proving actual damages of a specific monetary amount); Feitler v. Animation Celection, Inc., 13 P.3d 1044, 1050 (Or. Ct. App. 2000) (finding that a showing of "ascertainable loss" is satisfied so long as it is "capable of being discovered, observed, or established").

103. See, e.g., D.C. CODE ANN. § 28-3905(k)(1) (2001).

104. See, e.g., COLO. REV. STAT. § 6-1-113 (2004) (defining "any person" as an actual or potential consumer injured by defendant's goods, services, or property; as a successor in interest to an actual consumer who purchased from defendant; or as a person injured by defendant's deceptive trade practice in the person's occupation or business).

105. See infra notes 199-201 and accompanying text.

106. D.C. CODE ANN. § 28-3905(k)(1).

107. Wells v. Allstate Ins. Co., 210 F.R.D. 1, 8-9 (D.D.C. 2002). The pre-amendment version of the District of Columbia's CPA permitted recovery by "“[a]ny consumer who suffers any damage as a result of the use or employment of any person of a trade practice" in violation of the act. $I d$. at 8 (quoting the historical and statutory notes to D.C. Code $\S 28-3905$ (2000)).

108. Williams v. Purdue Pharma Co., 297 F. Supp. 2d 171, 176-78 (D.D.C. 2003). 


\section{B. Available Remedies}

Remedies available to private litigants also vary significantly. Minnesota law does not provide for money damages but only for injunctive relief. ${ }^{109}$ Arkansas, Florida, Indiana, Maine, Maryland, Mississippi, Nebraska, South Dakota, Texas, Wisconsin, and Wyoming limit a private litigant's recovery to actual damages, restitution, or equitable relief. ${ }^{110}$ Actual damages may include the difference between the market value of the good or service and either its value as received or the cost of repairing the goods. ${ }^{111}$ Damages for pain and suffering or emotional distress may also be available in some states. ${ }^{112}$

Most states provide for much more generous recovery. Several states provide that private litigants may recover statutory damages, which are the greater of actual damages or an amount ranging from \$25 in Massachusetts to $\$ 2000$ in Utah. ${ }^{113}$ State laws allow plaintiffs to receive the statutory minimum without proving actual damages. ${ }^{114}$ Nebraska law allows the court, in its discretion, to increase the award "to an amount which bears a reasonable relation to the actual damages" up to $\$ 1000$

109. Minn. Stat. AnN. § 325D.45 (West 2004); Simmons v. Modern Aero, Inc., 603 N.W.2d 336, 339 (Minn. Ct. App. 1999).

110. ARK. CODE ANN. § 4-88-113 (LexisNexis 2001); Fla. STAT. § 501.211(2) (2002); IND. Code AnN. § 24-5-0.5-4(b) (LexisNexis 1996); Me. Rev. StAt. ANN. tit. 10, § 1213 (1997); MD. Code AnN., Com. LAW § 13-408 (LexisNexis 2000); Miss. Code ANN. § 75-24-15(1) (West 1999); Neb. Rev. Stat. ANN. § 59-1609 (LexisNexis 2004); S.D. Codified LAWS § 37-24-31 (2004); TEX. Bus. \& COM. CODE $§ 17.50(b)(1)$ (Vernon 2002); WiS. STAT. ANN. § 100.18(11)(b)(2) (West Supp. 2004); WYo. STAT. ANN. § 40-12-108(b) (2005).

111. Rollins, Inc. v. Heller, 454 So. 2d 580, 585 (Fla. Dist. Ct. App. 1984); Viene v. Concours Auto Sales, Inc., 787 S.W.2d 814, 814 (Mo. Ct. App. 1990).

112. See Laurents v. La. Mobile Homes, 689 So. 2d 536, 542 (La. Ct. App. 1997) (stating that actual damages may include damages for mental anguish and humiliation); Avery v. Indus. Mortgage Co., 135 F. Supp. 2d 840, 844-45 (W.D. Mich. 2001) (holding that noneconomic damages are available under the Michigan Consumer Protection Act).

113. See AlA. CODE § 8-19-10(a)(1) (LexisNexis 2002) (greater of actual damages or \$100); CAL. CIV. CODE $§ 1780$ (West Supp. 2005) (actual damages but not less than \$1000); Colo. Rev. STAT. § 6-1-113(2) (2004) (greater of actual damages or \$500); MASS. GEN. LAWS ch. 93A, § 9(3) (1997) (greater of actual damages or \$25); MicH. CoMP. LAWS ANN. § 445.911(2) (West 2002) (greater of actual damages or \$250); MONT. CODE ANN. § 30-14-133(1) (2003) (greater of actual damages or \$500); N.M. STAT. ANN. § 57-12-10(B) (West 2000) (greater of actual damages or $\$ 100$ ); N.Y. GEN. BuS. LAW § 349(h) (McKinney 2004) (greater of actual damages or \$50); OR. REV. STAT. § 646.638(1) (2003) (greater of actual damages or \$200); PA. STAT. ANN. tit. 73, § 2019.2(a) (West Supp. 2005) (greater of actual damages or \$100); R.I. GEN. LAWS § 6-13.1-5.2(a) (2001) (greater of actual damages or \$200); UTAH CODE ANN. § 13-11-19(2) (2001) (greater of actual damages or \$2000); VA. CODE ANN. § 59.1-204(A) (Supp. 2005) (greater of actual damages or \$500); W. VA. CODE $§ 46 \mathrm{~A}-6-106(1)$ (Supp. 2005) (greater of actual damages or \$200).

114. See, e.g., Preferred Nat'l Ins. Co. v. Docusearch, Inc., 829 A.2d 1068, 1075 (N.H. 2003). 
when "damages are not susceptible of measurement by ordinary pecuniary standards."

States also have adopted different mechanisms for punishing bad conduct in private lawsuits under CPAs. About two-thirds of state laws provide for the tripling of actual damages (or the state-set minimum) or for punitive damages. Even among these states, the trigger for the imposition of punishment varies significantly. In nine states, treble damages are available if the jury finds that the defendant acted intentionally, willfully, knowingly, or in bad faith. ${ }^{116}$ In Colorado, for example, treble damages are available if it is established by clear and convincing evidence that the defendant engaged in "bad faith" conduct. ${ }^{17}$ Louisiana awards treble damages if the director or Attorney General previously put the defendant on notice of the violation. ${ }^{118}$ Similarly, Ohio, through its administrative rules, provides for treble damages for acts previously found to constitute violations by the Attorney General or by court decision when the decision is available in the Attorney General's public inspection files. ${ }^{119}$

On the other hand, Alaska, the District of Columbia, Hawaii, Louisiana, New Jersey, and North Carolina award three times actual damages, and Wisconsin awards two times actual damages, to every

115. NeB. Rev. StAT. ANN. § 59-1609 (LexisNexis 2004).

116. See COLO. REV. STAT. $§ 6-1-113(2)$ (a)(III) (allowing an award of three times the actual damages if it is shown by clear and convincing evidence that the defendant engaged in bad-faith conduct); GA. CODE ANN. § 10-1-399(c) (2000) (requiring an award of three times actual damages for intentional violations); MASS. GEN. LAWS ch. 93A, § 9(3) (providing a court with discretion to award up to three times actual damages for willful and knowing violations); N.H. REV. STAT. ANN. $\S$ 358-A:10 (LexisNexis 1995) (providing that a court may award up to three times actual damages, but not less than two times actual damages, for willful and knowing violations); N.M. STAT. ANN. § 57-12-10(B) (providing for the greater of treble damages or $\$ 300$ in cases of willful conduct); N.Y. GEN. BUS. LAW § 349(h) (providing for three times actual damages up to $\$ 1000$ for willful or knowing violations); S.C. CODE ANN. § 39-5-140(a) (1985) (providing for treble damages for willful or knowing violations); TENN. CODE ANN. § 47-18-109(a)(3) (2001) (providing for treble damages in cases of willful or knowing violations); VA. CODE ANN. § 59.1-204(A) (providing that the trier of fact may award up to the greater of three times actual damages or $\$ 1000$ for willful conduct); see also TEX. Bus. \& COM. CODE ANN. § 17.50(b)(1) (Vernon 2002) (providing that a plaintiff can recover for mental anguish and three times economic damages in cases of knowing violations and three times damages for mental anguish and economic damages in cases involving intentional conduct).

117. Colo. Rev. StAT. § 6-1-113(2)(a)(III). Oklahoma takes an alternative approach. It allows consumers to collect a civil penalty of $\$ 2000$ per violation if the defendant knowingly took advantage of a vulnerable consumer, or knew or should have known that the price was grossly excessive, there was no reasonable probability that the consumer would be able to pay for the good or service, or that the transaction was excessively one-sided in favor of the violator. OKLA. STAT. ANN. tit. 15, § 761.1(B) (West Supp. 2005).

118. LA. REV. STAT. ANN. § 51:1409(A) (2003).

119. See Ohio Rev. Code ANN. § 1345.09(B) (LexisNexis 2002). 
prevailing plaintiff in a CPA lawsuit. ${ }^{120}$ These states tend to look at treble damages as a way to encourage private enforcement of their CPAs by providing an economic incentive to sue in cases where actual damages may be small. ${ }^{121}$ A few states, such as Alabama, Montana, Vermont, and Washington, leave the decision of whether to impose treble damages to the court's broad discretion. ${ }^{122}$

In addition, at least fourteen states permit punitive damages in lawsuits under CPAs for conduct ranging from recklessness to intentional conduct or ill will or in cases involving flagrant or repeated violations. $^{123}$ In six of these jurisdictions, it appears that punitive damages may be awarded despite the availability of statutory or treble damages. ${ }^{124}$

120. See AlASKa StAT. § 45.50.531(a) (2004) (providing for the greater of treble damages or $\$ 500$ and any other relief the court deems proper); D.C. CODE ANN. § 28-3905(k) (LexisNexis 2001) (providing for the greater of treble damages or $\$ 1500$ per violation in addition to the potential for punitive damages); HAW. REV. STAT. ANN. § 480-13 (LexisNexis Supp. 2004) (providing for the greater of treble damages or \$1000); N.J. STAT. ANN. § 56:8-19 (West 2001) (providing for treble damages); N.C. GEN. STAT. § 75-16 (2003) (providing for treble damages); WiS. STAT. § 100.20(5) (West Supp. 2004) (providing for an award of twice the pecuniary loss).

121. See, e.g., United Labs., Inc. v. Kuykendall, 437 S.E.2d 374, 379 (N.C. 1993).

122. See ALA. CODE $\S 8-19-10$ (a)(2) (LexisNexis 2002) (permitting the court to award up to three times actual damages, in its discretion, based on "the amount of actual damages awarded, the frequency of the unlawful acts or practices, the number of persons adversely affected thereby and the extent to which the unlawful acts or practices were committed intentionally," among other relevant factors); MONT. CODE ANN. § 30-14-133(1) (2003) (providing the court with discretion to award treble damages); VT. STAT. ANN. tit. 9, § 2461(b) (1993) (providing for exemplary damages of up to three times actual damages); WASH. REV. CODE ANN. $§ 19.86 .090$ (West 1999) (providing the court with discretion to award up to three times actual damages not to exceed $\$ 10,000$ ).

123. See AlaSKa STAT. § 45.50.531(a) (permitting the court to award "other relief" as it deems proper); CONN. GEN. STAT. ANN. § 42-110g(a) (West Supp. 2005) (allowing the court, but not a jury, to award punitive damages in its discretion); D.C. CODE ANN. $§ 28-3905(\mathrm{k})(1)(\mathrm{C})$, (F) (providing the court with discretion to award punitive damages and any other relief the court deems proper); GA. CODE ANN. § 10-1-399(a) (2000) (authorizing exemplary damages for intentional violations); IDAHO CODE ANN. § 48-608(1) (2003) (authorizing the court to impose punitive damages in cases of flagrant or repeated violations); 815 ILL. COMP. STAT. ANN. 505/10a(a) (West Supp. 2005) (noting that a court has discretion to award any relief it deems proper, including punitive damages); KY. REV. STAT. ANN. § 367.220(1) (LexisNexis 1996) (authorizing the court to award punitive damages in its discretion); MO. ANN. STAT. § 407.025(1) (West 2001) (providing the court with discretion to award punitive damages); OR. REV. STAT. § 646.638(1) (2003) (authorizing a court or jury to award punitive damages); 73 PA. STAT. ANN. § 201-9.2(a) (West Supp. 2005) (stating that the court "may provide such additional relief as it deems necessary or proper"); R.I. GEN. LAWS § 6-13.1-5.2(a) (2001) (noting that punitive damages are available as necessary); see also ARK. CODE ANN. § 4-88-204 (2001) (allowing punitive damages in cases involving elderly or disabled claimants); Schmidt v. Amn. Leasco, 679 P.2d 532, 535 (Ariz. Ct. App. 1983) (finding that the jury has discretion to award punitive damages under Arizona's CPA if the defendant's conduct is reckless or shows spite or ill will); Stephenson v. Capano Dev. Inc., 462 A.2d 1069, 1076-77 (Del. 1983) (recognizing that a court may award punitive damages under the CPA statute if fraud is gross, oppressive, or aggravated, or in cases of breach of trust or confidence).

124. See D.C. Code AnN. § 28-3905(k); Ga. CODE ANN. § 10-1-399(a), (c); IdAHo CodE ANN. 
In most states, CPA remedies are considered cumulative in nature to other legal remedies. ${ }^{125}$ Thus, plaintiffs may sometimes obtain punitive damages in a lawsuit alleging a CPA violation, in addition to statutory or treble damages under the statute, by asserting common law causes of action. ${ }^{126}$ When a plaintiff is entitled to both punitive damages in conjunction with a common law claim for relief and to treble damages under a state statute, it appears that most jurisdictions require the plaintiff to elect a remedy to prevent double punishment. ${ }^{127}$

As one commentator recognized, "[p]erhaps no other statute... offers a greater depth or range of recovery than the Consumer Fraud Act. ... These remedies give the Act sharp teeth and provide an incentive to settle, sometimes for considerable money." 128

\section{Availability of Recovery of Attorneys' Fees and Costs}

Ordinarily, in civil litigation in the United States, parties are required to pay their own attorneys' fees and costs unless there is an explicit statutory provision authorizing an award of fees and costs to the prevailing party. Many little-FTC Acts provide such an authorization. ${ }^{129}$

§ 48-608(1); OR. Rev. Stat. § 646.638(1); 73 PA. Stat. AnN. § 201-9.2(a); R.I. Gen. LAwS $§ 6-$ 13.1-5.2(a).

125. See, e.g., ARIZ. REv. StAT. ANN. § 44-1533(A) (2003).

126. See, e.g., Wildstein v. Tru Motors, Inc., 547 A.2d 340, 342 (N.J. Super. Ct. Law Div. 1988) (finding that the New Jersey Consumer Fraud Act does not bar a plaintiff from collecting punitive damages for common law fraud in addition to treble damages under the Act).

127. Concrete Spaces, Inc. v. Sender, 2 S.W.3d 901, 908 (Tenn. 1999) ("When a plaintiff is entitled to both punitive damages in conjunction with a common law claim for relief and to treble damages under a statutory scheme, the majority of jurisdictions employ a version of the election of remedies doctrine to prevent double recovery of enhanced damages." (citing Lisa K. Gregory, Annotation, Plaintiff's Rights to Punitive or Multiple Damages When Cause of Action Renders Both Available, 2 A.L.R. 5th 449, 459 (1992))). See, e.g., Lexton-Ancira Real Estate Fund, 1972 v. Heller, 826 P.2d 819, 822-23 (Colo. 1992) (en banc) (finding that a treble damages award under the state's CPA precluded an award of punitive damages on the same facts); Hale v. Basin Motor Co., 795 P.2d 1006, 1012 (N.M. 1990) (holding that a plaintiff may not recover both punitive damages under a common law cause of action and treble damages under the state's Unfair Practices Act and must elect between the two to prevent double recovery); United Labs., Inc. v. Kuykendall, 437 S.E.2d 374, 379 (N.C. 1993) (holding that a plaintiff may not recover both treble and punitive damages based on allegations arising out of the same transaction or practice and requiring the plaintiff to elect a remedy after the verdict is rendered and before judgment is entered); see also ALA. CODE $\S 8-19-15$ (b) (LexisNexis 2002) (requiring plaintiffs to elect to bring a private action under the CPA or to bring an action at common law for fraud, misrepresentation, deceit, suppression of material facts, or fraudulent concealment).

128. Keller, supra note 2, at 477.

129. See, e.g., Alaska Stat. § 45.50 .537 (2004); ConN. Gen. Stat. AnN. § 42-110g (West Supp. 2005); D.C. Code ANN. § 28-3905(k)(1) (LexisNexis 2001); 815 Ill. Comp. StAT. AnN. 505/10a(c) (West Supp. 2005); IND. CODE ANN. § 24-5-0.5-4(b) (LexisNexis 1996); KAN. STAT. AnN. § 50-634(e) (1994); Ky. REV. StAT. AnN. § 367.220(3) (LexisNexis 1996); Md. CodE ANN. 
In fact, nearly half of the states require an award of reasonable legal fees and costs to every prevailing plaintiff. ${ }^{130}$ These provisions encourage plaintiffs' lawyers to bring consumer protection lawsuits because no matter how small the actual damages, they are, in many cases, guaranteed to receive their costs of bringing the lawsuit. A few states take a different approach and explicitly use an award of attorneys' fees and costs to punish a defendant for wrongdoing. ${ }^{131}$ Several CPAs provide a much more limited authorization for a prevailing defendant to recover attorneys' fees - when the lawsuit is found to be frivolous, i.e., it is groundless, or brought in bad faith or for the purpose of harassment. ${ }^{132}$ The Illinois, Montana, and Oregon CPAs appear to provide prevailing plaintiffs and defendants with an equal opportunity to request attorneys'

COM. LAW § 13-408(b) (LexisNexis Supp. 2004); Mich. Comp. LaWs $\S 445.911(2)$, (6) (West 2002); Mo. AnN. Stat. § 407.025(1) (West 2001); Mont. Code AnN. § 30-14-133 (2003); NeB. REV. STAT. § 59-1609 (2004); N.Y. GEN. Bus. LAW § 349(h) (McKinney 2004); OR. REV. STAT. § 646.638(3) (2003); 73 PA. STAT. ANN. § 201-9.2(a) (West Supp. 2005); TENN. CODE ANN. § 47-18109(e)(1) (2001); UtAH CODE ANN. § 13-11-19(5) (2001); WASH. Rev. CODE ANN. § 19.86.090 (West 1999).

130. See, e.g., Alaska Stat. § 45.50.537(a); ARK. Code AnN. § 4-88-113(f) (2001); Colo. ReV. STAT. § 6-1-113(2)(b) (2004); HAW. ReV. StAT. ANN. § 480-13 (LexisNexis 2002); LA. ReV. STAT. ANN. § 51:1409(A) (2003); MASS. GEN. LAWS ch. 93A, § 9(4) (West Supp. 2005); NEV. ReV. STAT. § 41.600(3)(b) (2003); N.H. REV. STAT. ANN. § 358-A-10 (1995); N.J. STAT. ANN. § 56:8-19 (West 2001); N.M. STAT. ANN. § 57-12-10(c) (LexisNexis 2000); OKLA. STAT. ANN. tit. 15, § 761.1 (West Supp. 2005); S.C. Code ANN. § 39-5-140(a) (1985); TeX. Bus. \& Com. Code ANN. § 17.50(d) (Vernon 2002); Wis. StaT. ANN. § 100.18(11)(b)(2) (West Supp. 2004); Wyo. Stat. ANN. § 40-12-108(b) (2005); see also GA. CODE ANN. § 10-1-399(d) (2000) (providing for an award of reasonable attorneys' fees and costs unless the plaintiff rejects a reasonable settlement offer); ME. REV. STAT. ANN. tit. 5, § 213(1-A) (2002) (providing for an award of reasonable attorneys' fees and costs unless the plaintiff rejected a settlement offer that was more favorable than the judgment). The language of Idaho's CPA appears to provide for a mandatory award of attorneys' fees, see IDAHO CODE $\S 48-608(4)$ (2003), but the Idaho Supreme Court has found prevailing plaintiffs are not automatically entitled to fees under the statute. See Israel v. Leachman, 72 P.3d 864, 867-68 (Idaho 2003).

131. See, e.g., MinN. STAT. ANN. § 325D.45 (West Supp. 2005) (providing for an award of attorneys' fees when the violation was willful); N.C. GEN. STAT. § 75-16.1(1) (2003) (authorizing an award of attorneys' fees where a defendant commits a willful violation and refuses to fully resolve the matter); N.D. CENT. CODE § 51-15-09 (1989) (requiring an award of attorneys' fees and costs where a defendant knowingly commits the violation).

132. See Colo. Rev. Stat. § 6-1-113(3); Idaho Code AnN. § 48-608(4) (2003); Kan. Stat. ANN. § 50-634(e)(1); LA. REV. STAT. ANN. § 51:1409(A); MD. CODE ANN., COM. LAW § 13-408(c); Minn. Stat. ANN. § 325D.45; Miss. Code AnN. § 75-24-15(3) (1999); N.C. Gen. Stat. § 7516.1(2) (2003); OHIO ReV. CODE ANN. § 1345.09(F)(1) (LexisNexis 2002); TEX. Bus. \& CoM. CODE ANN. § 17.50(c); UTAH CODE ANN. § 13-11-19(5)(a); see also OKLA STAT. tit. 15, § 761.1(A) (authorizing an award of attorneys' fees and costs not to exceed $\$ 10,000$ to a prevailing party, when the court finds a claim or defense asserted by a nonprevailing party "was asserted in bad faith, was not well grounded in fact, or was unwarranted by existing law or a good faith argument for the extension, modification, or reversal of existing law"); Casey v. Jerry Yusim Nissan, Inc., 694 N.E.2d 206, 209-10 (Ill. App. Ct. 1998) (finding that a court may only award attorneys' fees to a prevailing defendant when a plaintiff acted in bad faith). 
fees from the court. ${ }^{133}$ With the exception of a few states such as Arizona and Delaware, ${ }^{134}$ most states do not follow in the CPA context the traditional "American" rule, which requires that each party pay for its own legal expenses.

\section{Availability of Trial by Jury}

Courts vary in their interpretations of CPAs regarding the availability of a jury trial, ${ }^{135}$ though the effect of having a jury or judge decide CPA claims is unclear. ${ }^{136}$ CPAs in a few states, such as Connecticut, Maine, Vermont, and Virginia, explicitly provide for trial by jury. ${ }^{137}$ Most state laws do not contain a provision addressing the availability of a jury trial, and in those states, some courts have allowed consumer protection

133. See 815 Ill. Comp. StAT. AnN. 505/10a(c) ("[T]he Court... may award ... reasonable attorneys' fees and costs to the prevailing party."); MONT. CODE ANN. § 30-14-133(3) (“[T]he court may award the prevailing party reasonable attorneys' fees incurred in prosecuting or defending the action.”); OR. REv. STAT. § 646.638(3); see also Dillree v. Devoe, 724 P.2d 171, 176 (Mont. 1986) (finding that the defendant was entitled to attorneys' fees even though the plaintiff prevailed on the main controversy where the defendant successfully established that the Montana Consumer Protection Act did not apply).

134. See Sellinger v. Freeway Mobile Home Sales, Inc., 521 P.2d 1119, 1123 (Ariz. 1974) ("Attorney's fees may only be awarded where an agreement specifically provides for them or when specifically authorized by statute.”); Stephenson v. Capano Dev. Inc., 462 A.2d 1069, 1078 (Del. 1983) ("[A]ttorney's fees are not generally recoverable unless there is a specific statutory authorization ....").

135. See generally Karen K. Peabody, Annotation, Constitutional Right to Jury Trial in Cause of Action Under State Unfair or Deceptive Trade Practices Law, 54 A.L.R. 5th 631 (2004).

136. Given the tendency of media and legal commentators to attribute the trend of skyrocketing verdicts to "out-of-control" juries, some may instinctively believe that CPA claims in states not providing for a jury trial would have more reasonable outcomes. This is not necessarily the case. For instance, two of Illinois's largest judgments have been rendered by judges, not juries, and both involved cases brought as class action lawsuits under the Illinois Consumer Fraud and Deceptive Businesses Practices Act, which Illinois courts have interpreted to not permit a jury trial. See Avery v. State Farm Mut. Auto. Ins. Co., 746 N.E.2d 1242 (Ill. App. Ct. 2001) (awarding \$130 million in disgorgement damages and $\$ 600$ million in punitive damages on Consumer Fraud Act claims in addition to $\$ 455$ million awarded by a jury on the plaintiffs' breach of contract claims), rev'd, 835 N.E.2d 801 (Ill. 2005) (finding that non-residents may maintain an action under Illinois's Consumer Fraud Act only if the circumstances relating to the action occur primarily and substantially in Illinois, cautioning that plaintiffs may not recast contract claims as CPA claims, and finding that an individual claim should be dismissed because the plaintiff failed to show actual deception); Price v. Philip Morris, Inc., No. 00-L-112, 2003 WL 22597608 (Ill. Cir. Ct., Mar. 21, 2003) (awarding a class of smokers $\$ 7.1$ billion in compensatory damages and $\$ 3$ billion in punitive damages in an action brought under the Consumer Fraud Act related to light cigarettes, discussed infra notes 228 to 233 and accompanying text) overruled on other grounds, 793 N.E.2d 942 (Ill. App. Ct. 2003), vacated, No. 96644, 2003 Ill. LEXIS 2625 (Ill. Sept. 16, 2003). These cases further illustrate the power judges have in interpreting and deciding private lawsuits under CPAs.

137. See, e.g., Conn. Gen. Stat. Ann. § 42-110g(g) (West Supp. 2005); Me. Rev. Stat. AnN. tit. 5, § 213(1) (2002); VT. STAT. ANN. tit. 9, § 2461(c) (1993); VA. CODE ANN. § 59.1-206(E) (2001). 
claims to be heard by a jury. ${ }^{138}$ Illinois, Minnesota, and Nebraska courts have found that claims under their respective states' CPAs are to be decided by a judge, either because the right to a jury trial is not available in actions not existing at common law or because the action is primarily equitable in nature. ${ }^{139}$ Georgia, Kentucky, and Massachusetts courts have found that there is no right to a jury trial for CPA claims but that a jury trial is available at the court's discretion. ${ }^{140}$ Connecticut provides that while a jury decides liability and compensatory damages, the judge decides whether to award punitive damages, costs, attorneys' fees and their amount, as well as whether to grant any injunctive relief. ${ }^{141}$ Finally, in North Carolina, the jury serves as the fact finder and determines whether the defendant committed the alleged acts, the extent to which the plaintiff was injured, and whether the defendant's conduct caused the plaintiff's injury. ${ }^{142}$ Determination of whether a particular act is unfair or deceptive, however, is a question of law for the court in North Carolina. ${ }^{143}$

\section{E. Availability and Restrictions on Class Action Lawsuits}

The ability to bring a class action lawsuit under CPAs also varies from state to state, as does the recovery available in such lawsuits. Consumer protection statutes in several southern states, as well as

138. See, e.g., Williams v. First Gov't Mortg. \& Investors Corp., 225 F.3d 738, 745 (D.C. Cir. 2000) (interpreting District of Columbia law); Chicken Unlimited, Inc. v. Bockover, 374 So. 2d 96, 96-97 (Fla. Dist. Ct. App. 1979); White v. Mock, 104 P.3d 356, 363-64 (Idaho 2004); Boncosky Servs., Inc. v. Lampo, 751 So. 2d 278, 284 (La. Ct. App. 1999); Peterson v. Boat Sales, Inc., No. 248733, 2004 WL 2952608, at *1 (Mich. Ct. App. Dec. 21, 2004); Cohen v. Express Fin. Servs., Inc., 145 S.W.3d 857, 861 (Mo. Ct. App. 2004); U.W. Marx, Inc. v. Bonded Concrete, Inc., 776 N.Y.S.2d 617, 619 (N.Y. App. Div. 2004); Reichert v. Ingersoll, 480 N.E.2d 802, 804 (Ohio 1985); Valley Nissan, Inc. v. Davila, 133 S.W.3d 702, 707 (Tex. App. 2003); Horan v. Tpk. Ford, 433 S.E.2d 559, 563 (W. Va. 1993)

139. See Martin v. Heinold Commodities, Inc., 643 N.E.2d 734, 754-55 (Ill. 1994) (finding that "an action under the Consumer Fraud Act [is] a new statutory right created by the legislature and, as such, does not confer the right to a jury trial" and finding that the legislature intended that such actions be tried without a jury); State v. Alpine Air Prods., Inc., 490 N.W.2d 888, 895 (Minn. Ct. App. 1992) (finding that the trial court properly denied the plaintiff's request for a jury trial because claims under the state's CPA are equitable in nature), aff'd, 500 N.W.2d 788 (Minn. 1993); State $e x$ rel. Douglas v. Schroeder, 384 N.W.2d 626, 629-30 (Neb. 1986) (finding that because the CPA "seeks to prevent prejudicial conduct rather than merely compensate such damage as may flow therefrom" there is no right to a jury trial).

140. Regency Nissan, Inc. v. Taylor, 391 S.E.2d 467, 470-71 (Ga. Ct. App. 1990); Stevens v. Motorists Mut. Ins. Co., 759 S.W.2d 819, 820 (Ky. 1988); Travis v. McDonald, 490 N.E.2d 1169, 1172-73 (Mass. 1986).

141. Conn. Gen. Stat. AnN. § 42-110g(g).

142. Gray v. N.C. Ins. Underwriting Ass'n, 529 S.E.2d 676, 681 (N.C. 2000).

143. Id. 
Montana, explicitly prohibit class actions. ${ }^{144}$ On the other hand, the laws of at least fourteen states and the District of Columbia expressly permit class action lawsuits. ${ }^{145}$ The little-FTC Acts in just more than half of the states are silent on whether class action relief is available under the statute: they neither specifically authorize nor preclude class action relief. In such cases, courts have often found class action relief available. ${ }^{146}$ A business can face both a class action lawsuit and a state Attorney General action arising out of the same conduct. ${ }^{147}$

A few states that allow for class action litigation under their CPAs place limits on claims or recovery in such suits. For example, Colorado, New York, Ohio, Oregon, and Utah laws provide that class members may not receive more than actual damages in a class action lawsuit; they are not entitled to the minimum amount per violation or treble damages otherwise provided by statute. ${ }^{148}$ Similarly, New Mexico limits receipt of treble damages to class representatives while allowing class members to recover only actual damages. ${ }^{149}$ Utah's unique law permits class actions only where a defendant would have had notice that its conduct constituted a violation of the Consumer Sales Practices Act. ${ }^{150}$ Class actions are only permitted where the claim is premised on (1) a violation of a rule promulgated by the state agency regulating consumer

144. ALA. CODE § 8-19-10(f) (LexisNexis 2002); GA. CODE ANN. § 10-1-399(a) (2000); LA. ReV. StAT. AnN. § 51:1409(A) (2003); Miss. COde AnN. § 75-24-15(4) (2000); Mont. Code AnN. $\S 30.14-133(1)$ (2003); S.C. CODE ANN. § 37-5-202(1), (3) (2002).

145. CAL. Civ. Code $\S 1781$ (West 1998); D.C. CODE ANN. § 28-3905(k) (LexisNexis 2001); HaW. Rev. Stat. ANN. §§ 480-13(c) (LexisNexis Supp. 2004); Idaho Code AnN. § 48-608(1) (2003); Ind. Code ANN. § 24-5-0.5-4(b) (LexisNexis 1996); Kan. STAT. AnN. § 50-634(b)-(d) (1994); Mass. Gen. Laws ANN. ch. 93A, § 9(2) (West Supp. 2005); Mich. Comp. Laws ANN. § 445.911(3) (West 2002); Mo. AnN. Stat. § 407.025(2)-(3) (West 2001); N.H. ReV. STAT. ANN. § 358-A:10-a (LexisNexis Supp. 2004); N.M. STAT. ANN. § 57-12-10(E) (LexisNexis 2000); ОhiO REv. CODE ANN. § 1345.09(B) (LexisNexis 2002); R.I. GEN. LAWS § 6-13.1-5.2(b) (2001); UTAH CODE ANN. § 13-11-19(3) (2001); WYO. STAT. ANN. § 40-12-108(b) (2005).

146. See, e.g., In re Warfarin Sodium Antitrust Litig., 212 F.R.D. 231, 247-48 (D. Del. 2002); London v. Green Acres Trust, 765 P.2d 538, 545 (Ariz. Ct. App. 1988); Waugh v. Philpot, 868 So. 2d 699, 700 (Fla. Dist. Ct. App. 2004); Arthur v. Microsoft Corp., 676 N.W.2d 29, 31 (Neb. 2004); Super Glue Corp. v. Avis Rent A Car Sys., Inc., 517 N.Y.S.2d 764, 766 (N.Y. App. Div. 1987); Smith v. Behr Process Corp., 54 P.3d 665, 675 (Wash. Ct. App. 2002); $c f$. Chaffin v. Norwegian Cruise Line Ltd., No. 02A01-9803-CH-00080, 1999 WL 188295, at*2 n.1 (Tenn. Ct. App. Apr. 7 , 1999) ("Interestingly, [the Tennessee Consumer Protection Act] authorizes persons to "bring an action individually,' yet Plaintiffs assert this action both individually and as representatives on behalf of a class. Though we are unaware of any prior Tennessee case addressing this issue, this issue is not presently before this Court, and we therefore express no judgment or opinion regarding it.").

147. See, e.g., London, 765 P.2d at 545 .

148. Colo. Rev. StAT. § 6-1-113(2) (2004); N.Y. C.P.L.R. § 901(b) (McKinney 1976); ОhIO Rev. Code ANN. § 1345.09(E); UTAH CODE ANN. § 13-11-19(2); OR. R. Civ. P. 32(K).

149. N.M. STAT. ANN. §57-12-10(E).

150. UtAh CODE ANN. §13-11-19(4)(a). 
transactions, (2) conduct declared a violation of the act by the final judgment of a court made available for public dissemination by the agency, or (3) a violation of a consent judgment by the defendant. ${ }^{151}$

\section{F. Statutes of Limitations}

Like other elements of CPAs, the time period for bringing a lawsuit and the trigger for when this period begins to run varies from state to state. Statutes of limitations range from one year ${ }^{152}$ to six years. ${ }^{153}$ Most states have adopted something in between. ${ }^{154}$ In addition, some states apply a "discovery rule," under which the statute of limitations begins to run when a violation or injury resulting from a violation is or should have been discovered. ${ }^{155}$ Other state laws have adopted an occurrencebased statute that sets a fixed time period in which to bring lawsuits from the date of the transaction at issue. ${ }^{156}$ At least three states, Alabama,

151. Id.

152. See, e.g., LA. REV. STAT. ANN. § 51:1409(E) (2003) (requiring actions to be brought within one year of the transaction); OR. REV. STAT. § 646.638(6) (2003) (requiring actions to be brought within one year of discovery of the unlawful act); WYO. STAT. ANN. § 40-12-109 (2005) (requiring action to be brought within one year of initial discovery of the unlawful practice); Teran v. Citicorp Person-to-Person Fin. Ctr., 706 P.2d 382, 389 (Ariz. Ct. App. 1985) (requiring private lawsuits to be brought within one year of when fraud was discovered or could have been discovered).

153. See, e.g., Мich. Comp. Laws AnN. § 445.911(7) (West 2002); Minn. Stat. AnN. § 541.05(2) (West Supp. 2005); N.D. Cent. CODE § 28-01-16(2) (1991); VT. STAT. ANN. tit. 12, § 511 (2002); State v. Bob Chambers Ford, Inc., 522 A.2d 362, 364 (Me. 1987) (finding that a consumer may bring an action within six years of reasonable notice of the action); Gabriel v. O'Hara, 534 A.2d 488, 495 (Pa. Super. Ct. 1987) (holding that claims under the Unfair Trade Practices and Consumer Protection Law fall within the ambit of the six-year "catchall" limitations period).

154. See, e.g., ConN. Gen. StAT. ANN. § 42-110g(f) (West Supp. 2005) (three years after the violation); D.C. CODE ANN. § 28-3905(d)(1) (LexisNexis 2005) (three years); IDAHO CODE ANN. § 48-619 (2003) (two years after the cause of action accrues); MASS. GEN. LAWS ANN. ch. 260, § 5A (West 2004) (four years after the cause of action accrues); NEB. REV. STAT. § 59-1612 (2004) (four years after the cause of action accrues); OHIO REV. CODE ANN. § 1345.10(C) (LexisNexis 2002) (two years from the actual violation); S.C. CODE ANN. § 39-5-150 (1985) (three years after discovery of the unlawful conduct); S.D. CODIFIED LAWs § 37-24-33 (2004) (two years after occurrence or discovery of the conduct); UTAH CODE ANN. § 13-11-19(8) (two years after the occurrence or one year after termination of government proceedings); VA. CODE ANN. § 59.1-204.1 (2001) (two years after accrual of the action); WIS. STAT. ANN. § 100.18(11)(b)(3) (West 2004) (three years after occurrence of the unlawful act).

155. See, e.g., Alaska Stat. § 45.50.531(f) (2004); Colo. Rev. Stat. § 6-1-115 (2004); Nev. ReV. StAT. § 11.190(3)(d) (2003); N.H. ReV. STAT. ANN. § 358-A:3(IV-a) (LexisNexis 2004); OR. Rev. STAT. § 646.638(6); Tiberi v. Cigna Corp., 89 F.3d 1423, 1430 (10th Cir. 1996) (finding that the statute of limitations under New Mexico's Unfair Practices Act is four years after the plaintiff discovered or should have discovered the violation); Univ. of Vt. v. W.R. Grace \& Co., 565 A.2d 1354, 1357 (Vt. 1989) (interpreting VT. STAT. ANN. tit. 12, § 511 as requiring actions to be brought within six years of discovery of the injury).

156. See, e.g., Cal. Civ. Code $\S 1783$ (West 1998); Conn. Gen. Stat. Ann. § 42-110g(f) (West Supp. 2005); IND. CODE ANN. § 24-5-0.5-5(b) (LexisNexis 1996); Ky. REV. STAT. ANN. § 367.220(5) (LexisNexis 1996); LA. Rev. Stat. AnN. § 51:1409(E); Mich. Comp. LAwS AnN. § 
Tennessee, and Texas, combine a discovery rule with an absolute limit on the bringing of lawsuits under their consumer protection laws. ${ }^{157}$

\section{G. Miscellaneous Limitations and Exemptions}

CPAs have some common exceptions. Maryland is one of several states excluding providers of professional services, such as certified public accountants, lawyers, and health care providers, from its CPA. ${ }^{158}$ Michigan courts have developed a similar "learned professions" exception. ${ }^{159}$ Most state laws defer to the expertise of state and federal government agencies by exempting regulated conduct from the CPA, particularly when the conduct is explicitly authorized by law. ${ }^{160}$ Some

445.911(7); OHIO Rev. CODE AnN. § 1345.10(C); UtAH COdE AnN. § 13-11-19(8); Wis. STAT. ANN. § 100.18(11)(b)(3); Tuttle v. Lorillard Tobacco Co., 377 F.3d 917, 926 (8th Cir. 2004) (citing MinN. Stat. ANN. § 541.05(1)(2)); Gaidon v. Guardian Life Ins. Co., 750 N.E.2d 1078, 1083-84 (N.Y. 2001) (interpreting N.Y.C.P.L.R. § 214(2) (McKinney 2003)).

157. See ALA. CODE $§ 8-19-14$ (LexisNexis 2002) (providing that a claim must be filed within one year of when the plaintiff discovers or should have reasonably discovered the act or practice, but not more than four years after the date of the transaction); TENN. CODE ANN. § 47-18-110 (Supp. 2004) (providing that a claim must be filed within one year of discovery of the unlawful practice, but not more than five years of the date of the transaction); TEX. BUS. \& COM. CODE ANN. $\$ 17.565$ (Vernon 2002) (providing that a claim must be filed within two years of occurrence or within two years of when the consumer discovered or reasonably could have discovered the occurrence of the violation).

158. See Md. Code AnN., Com. LAW § 13-104(1) (LexisNexis 2004).

159. See Nelson v. Ho, 564 N.W.2d 482, 486-87 (Mich. Ct. App. 1997) (holding that the professional activities of physicians are not included in the meaning of trade or commerce and that physicians may only be sued under the Michigan Consumer Protection Act for entrepreneurial activities).

160. About two-thirds of CPAs specifically exempt acts or transactions regulated by, authorized by, or in compliance with rules or regulations of a federal or state government agency. See ALASKA StAT. § 45.50.481(a) (2004); ARIZ. Rev. StAT. ANN. § 44-1523 (2003); ARK. CODE ANN. § 4-88101(1) (2001); Colo. Rev. Stat. § 6-1-106(1) (2004); ConN. Gen. StAT. ANN. § 42-110c(a); DeL. Code AnN. tit. 6, § 2513(b) (1999); Fla. Stat. ANN. § 501.212 (West 2005); GA. Code. ANN. §§ 10-1-374, -396 (2000); HAW. ReV. Stat. ANN. § 481A-5 (LexisNexis Supp. 2004); IdAHO Code AnN. § 48-605 (2003); 815 Ill. Comp. Stat. AnN. 505/10b(1) (West. Supp. 2005); IND. Code ANN. § 24-5-0.5-6 (LexisNexis 1996); Iowa CodE ANN. § 714.16(14) (West 2003); Ky. ReV. STAT. AnN. §367.176(2) (LexisNexis 1996); La. Rev. Stat. AnN. § 51:1406 (2003); Me. Rev. Stat. ANN. tit. 5, § 208 (2002); MASs. GEN. LAWS ANN. ch. 93A, § 3 (West 1997); Mich. CoMP. LAWS AnN. $§ 445.904$ (West 2002); MinN. Stat. AnN. § 325D.46 (West 2004); Neb. ReV. Stat. AnN. §§ 59-1617, 87-304 (LexisNexis 2004); NEV. REV. STAT. §598.0955 (2003); N.M. STAT. ANN. § 57$12-7$ (West 2000); N.Y. Gen. Bus. LaW § 350-d (McKinney 2004); Ohio Rev. Code ANN. § 1345.12 (LexisNexis 2002); OKLA. STAT. ANN. tit. 15, § 754 (West Supp. 2005); Or. ReV. STAT. § 646.612 (2003); R.I. GEN. LAWS § 6-13.1-4 (2001); S.C. CODE ANN. § 39-5-40 (1985); S.D. CODIFIED LAWS $\$ 37-24-10$ (2004); TENN. CODE ANN. § 47-18-111(a) (2001); TEX. Bus. \& COM. Code ANN. § 17.49(b) (Vernon 2002); UtAH CODE ANN. § 13-11-22(1)(a), (e) (2001); VA. Code ANN. § 59.1-199 (2001); WASH. REV. CODE ANN. § 19.86.170 (West 1999); Wyo. STAT. ANN. § 40-12-110(a) (2005). These exemptions may rise in importance, particularly in private consumer protection litigation involving highly regulated industries, following the Illinois Supreme Court's 
state courts, such as those in Colorado, Nebraska, and Washington, require that private actions under $\mathrm{CPA}$ acts be brought "in the public interest" and not just to redress a private wrong. ${ }^{161}$ The public interest restriction reflects the goal of the creation of private rights of action, namely "to insure more effective enforcement within the context of the marketplace" by "protect[ing] the public from a generalized course of conduct without over-regulation of the state's businesses."162

\section{THE EXPANDED AND ABUSIVE USE OF PRIVATE RightS OF ACTION UNDER STATE CONSUMER PROTECTION STATUTES}

In the first ten to twenty years of their adoption, the private remedy provisions of CPAs were used only sporadically by consumers. ${ }^{163}$ Even then, scholars predicted that the power of these provisions had been "severely underestimated."164 In recent years, both the use and abuse of these statutes have resulted in increased scrutiny and criticism from scholars and commentators. ${ }^{165}$

The private right of action included in state CPAs did not, in many cases, come with the procedural and proof protections required in ordinary common law fraud actions. For example, many CPAs do not require a showing of actual reliance on the alleged misrepresentation or omission. In addition, cases alleging fraudulent conduct under consumer protection statutes do not need to be pled with particularity as required in common law actions. ${ }^{166}$ This has allowed plaintiffs to bring broad claims

decision in Price v. Philip Morris, No. 96326, 2005 WL 3434368 (Ill. Sup. Ct. Dec. 15, 2005), discussed infra notes 252-58 and accompanying text.

161. See, e.g., Hall v. Walter, 969 P.2d 224, 234 (Colo. 1998) (en banc); Martinez v. Lewis, 969 P.2d 213, 222 (Colo. 1998) (en banc); Nelson v. Lusterstone Surfacing Co., 605 N.W.2d 136, 142 (Neb. 2000); Hangman Ridge Training Stables, Inc. v. Safeco Title Ins. Co., 719 P.2d 531, 535 (Wash. 1986) (en banc); see also Oswego Laborers' Local 214 Pension Fund v. Marine Midland Bank, N.A., 647 N.E.2d 741, 744 (N.Y. 1995) (finding that New York's Deceptive Business Acts and Practices law does not apply to "private contract disputes, unique to the parties").

162. David J. Dove, Washington Consumer Protection Act-Public Interest and the Private Litigant, 60 WASH. L. REV. 201, 202 (1984) (internal quotations omitted).

163. Marshall A. Leaffer \& Michael H. Lipson, Consumer Actions Against Unfair or Deceptive Acts or Practices: The Private Uses of Federal Trade Commission Jurisprudence, 48 GEO. WASH. L. REV. 521, 522 (1980).

164. Id.

165. See Keller, supra note 2, at 474 ("In cases unnoticed by many of us, the appellate courts have been shaping the Act into a powerful weapon.”); see generally Keith E. Andrews, Louisiana Unfair Trade Practices Act: Broad Language and Generous Remedies Supplemented by a Confusing Body of Case Law, 41 LoY. L. REV. 759 (1996).

166. See, e.g., Snierson v. Scruton, 761 A.2d 1046, 1049 (N.H. 2000) (“A plaintiff cannot allege fraud in general terms, but must specifically allege the essential details of the fraud and the facts of the defendants' fraudulent conduct."). 
immediately and then seek evidence to support their allegations later. The scope of remedies provided by state CPAs also differs significantly from that of the federal law. Rather than provide for a cease-and-desist order and other injunctive and remedial relief that would help the public, some of these state laws have the potential for substantial damages when a business is found to have run afoul of a highly ambiguous law. Finally, three out of four states allow for class action lawsuits under their CPAs, providing the potential for extraordinary damage awards and a strong incentive for plaintiffs' lawyers to bring nominal claims on behalf of thousands of people for inadvertent or technical violations of the law.

CPAs have blossomed into a powerful tool for plaintiffs' lawyers. Their broad wording allows lawyers to use them as a catchall statutory cause of action, with the potential for substantial damages and an award of attorneys' fees. Although Congress passed the 1938 FTC Act to provide a means for the federal government to regulate deceptive advertising and coercive sales methods, state little-FTC Acts are now invoked to attack a broad range of issues. Some of these "fringe" cases include insurance and banking practices, sales of securities, commercial transactions, residential rental situations, and even personal injury claims. $^{167}$

Moreover, the relaxation of the need to show proof of actual, reasonable reliance and damages has made it easier to bring class action lawsuits. Thus, some courts have found that plaintiffs need only show a causal link between the alleged deceptive conduct and an injury to satisfy class certification standards under CPAs. ${ }^{168}$ These already minimal requirements are further diminished in class action lawsuits, where some courts have "presumed" elements such as causation when the plaintiffs have otherwise established a violation under the act. ${ }^{169}$ In addition, courts have allowed multi-state or nationwide class actions that involve application of multiple state CPAs. ${ }^{170}$ As this Article shows, given the numerous differences among state laws and the need to show individual

167. See Franke \& Ballam, supra note 68, at 360, 361-62 n.90, 423 (examining the expansive use of CPAs in Connecticut, Illinois, Massachusetts, New Jersey, North Carolina, Pennsylvania, and Texas and arguing in support of a broad reading and application of CPAs by courts).

168. See, e.g., In re Warfarin Sodium Antitrust Litig., 212 F.R.D. 231, 248 (D. Del. 2002) (stating that "[w]hether and to what extent the conduct of a defendant caused injury to plaintiffs and the class" is a question of fact).

169. See, e.g., Varacallo v. Mass. Mut. Life Ins. Co., 752 A.2d 807, 817 (N.J. Super. Ct. App. Div. 2000) (stating that a "defendant who violates the art" is liable regardless of whether a person has been injured).

170. E.g., Warfarin Sodium, 212 F.R.D. at 248 n.15. 
reliance or damages, it is particularly inappropriate to certify national class actions in such cases.

\section{A. Case Study: California's Section 17200}

Until recently, California's Unfair Competition Law (UCL) ${ }^{171}$ was arguably the broadest consumer fraud statute in the nation. ${ }^{172}$ Originally, the UCL provided a statutory cause of action for traditional business torts. ${ }^{173}$ In 1933, California rewrote the UCL to provide injunctive relief for unfair competition, which was defined to include fraudulent business practices and deceptive advertising. ${ }^{174}$ In addition, the rewritten UCL allowed any member of the public to bring suit. ${ }^{175}$ In the 1970 s, the California General Assembly further amended the law to allow plaintiffs to seek restitution and moved the law to begin at Section 17200 of the California Business and Professional Code. ${ }^{176}$ The California Supreme Court further expanded the scope of the law in 1988 when it ruled that a plaintiff did not need to be injured to bring an action under Section $17200,{ }^{177}$ and in 1992 the General Assembly amended the law to allow private lawsuits stemming from out-of-state activities. ${ }^{178}$

The gradual and consistent loosening of the UCL allowed plaintiffs to file "Section 17200" or "private attorney general" actions without meeting the basic standing rules that California law normally required. Rather, the UCL allowed almost any individual to bring an action on behalf of him or herself, a representative class, or the general public. ${ }^{179}$

171. The law is codified at CAL. Bus. \& Prof. Code $\S \S 17200-17210$ (West 1997 \& Supp. 2005). The UCL recently was amended by Proposition 64. See infra notes 199-201 and accompanying text.

172. See Robert C. Fellmeth, California's Unfair Competition Act: Conundrums and Confusions, in 26 CALIFORNIA LAW REVISION COMMISSION REPORTS 227, 239-49 (1995) (comparing California's UCL to sixteen other states and concluding that it is the broadest). California has also adopted a less frequently used "Consumer Legal Remedies Act," which broadly prohibits "unfair and deceptive business practices" and provides consumers with a private right of action to obtain actual damages but not less than $\$ 1000$ in a class action, injunctive relief, restitution, punitive damages, and any other relief that the court deems proper. CAL. CIV. CODE $\S \S 1750-1784$ (West 1997 \& Supp. 2005).

173. Fellmeth, supra note 172, at 231.

174. See Kraus v. Trinity Mgmt. Servs., Inc., 999 P.2d 718, 727 (Cal. 2000) (discussing the 1933 amendments).

175. Id.

176. Id.

177. People v. Cappuccio, Inc., 251 Cal. Rptr. 657, 663 (Cal. Ct. App. 1988).

178. Stop Youth Smoking Addiction, Inc. v. Lucky Stores, Inc., 950 P.2d 1086, 1097 (Cal. 1998)

179. CAL. Bus. \& Prof. CODE $\S 17204$ (West 1997 \& Supp. 2005). The UCL was recently amended by Proposition 64. See infra note 199 and accompanying text. 
The law did not require a plaintiff to show that he or she or anyone else had suffered any harm. ${ }^{180}$ Although plaintiffs were permitted to bring claims under Section 17200 as class actions, ${ }^{181}$ a plaintiff could avoid satisfying the procedural safeguards normally required in California class actions - adequacy, commonality, numerously, and superiority ${ }^{182}$ - by merely bringing a claim as a representative under the statute, which did not require these safeguards. "Defendants did not necessarily receive the protections that are available in class actions, including finality and protection against more than one lawsuit arising from essentially the same allegations." $" 183$

Section 17200 allowed (and continues to allow) plaintiffs to bring claims for fraudulent conduct and unfair acts. Fraudulent conduct is conduct that is "likely to deceive" members of the public. ${ }^{184}$ Unlike plaintiffs who bring common law fraud and misrepresentation claims, plaintiffs who brought Section 17200 actions prior to 2004 did not need to show actual deception, reasonable reliance, or damages. ${ }^{185}$

It is unclear what constitutes an "unfair" act. The California Supreme Court has rejected two different appellate court attempts to define the term because the attempts were "too amorphous and provided little guidance." ${ }^{\prime 86}$ However, two California appellate courts have found that unfair practices include violations of public policy as demonstrated by statutory or regulatory prohibitions. ${ }^{187}$ Thus, under Section 17200, an unfair business practice may include any practice that violates another law. California courts have interpreted the statute as allowing a private cause of action for virtually any violation of a state or federal law or regulation. ${ }^{188}$ In fact, the California Supreme Court found that an

180. See Stop Youth Smoking, 950 P.2d at 1097 (stating that a private individual can seek injunctive relief).

181. Corbett v. Superior Court, 125 Cal. Rptr. 2d 46, 55 (Cal. Ct. App. 2002).

182. CAL. Civ. Proc. CodE $\S \S 382,384$ (West 2004).

183. Alexander S. Gareeb, Evaluating the Retroactive Application of Proposition 64, 28 L.A. LAW., Mar., 2005, at 10.

184. Lavie v. Procter \& Gamble Co., 129 Cal. Rptr. 2d 486, 495 (Cal. Ct. App. 2003).

185. Comm'n on Children's Television, Inc. v. Gen. Foods Corp., 673 P.2d 660, 668-69 (Cal. 1983).

186. Cel-Tech Commc'ns, Inc. v. L.A. Cellular Tel. Co., 973 P.2d 527, 543 (Cal. 1999) (rejecting a determination of unfairness based on a weighing of the defendant's conduct against the gravity of harm to the alleged victim or a determination that the act offends an established public policy or is immoral, unethical, oppressive, unscrupulous or substantially injurious to consumers).

187. See Scripps Clinic v. Superior Court, 134 Cal. Rptr. 2d 101, 115-17 (Cal. Ct. App. 2003); Gregory v. Albertsons, Inc., 128 Cal. Rptr. 2d 389, 395 (Cal. Ct. App. 2002).

188. See, e.g., Bank of the West v. Superior Court, 833 P.2d 545, 553 (Cal. 1992). Courts in other states have found that CPA claims may not be alleged to effectively establish a private right of action for a violation of a statute where the legislature did not provide for such a remedy. See, e.g., 
individual could bring a lawsuit under Section 17200 as a violation of a predicate statute, even if that law did not allow for a private right of action. ${ }^{189}$

Section 17200 continues to provide courts with broad equitable power to make such orders and judgments as necessary to prevent future unfair acts and to restore any person in the amount acquired by the unfair act. ${ }^{190}$ The statute does not provide for money damages beyond restitution. Yet, a court may order restitution even to those who were never influenced by the deceptive act "if the court determines that such a remedy is necessary to deter future violations... or to foreclose the defendant's retention of ill-gotten gains." 191

The loosened rules for standing and the broad scope of Section 17200 actions led to substantial abuse involving small and large businesses alike. ${ }^{192}$ For example, plaintiffs used Section 17200 suits to attack auto dealers and homebuilders for technical violations such as using the wrong font size or an abbreviation, such as "APR," instead of "Annual Percentage Rate." 193 They went after hardware stores for advertising locks as "Made in the U.S.A.," when the locks included six screws made in Taiwan. ${ }^{194}$ They sued nail salons that used the same nail polish bottle for more than one customer. ${ }^{195}$ And one Section 17200 suit involved a restaurant in which the bathroom mirror was an inch too high

Conboy v. AT \& T Corp., 241 F.3d 242, 258 (2d Cir. 2001) (holding that where New York law only provided that the Attorney General or a District Attorney could commence an action for violation of the Fair Debt Collection Practices Act, "[p]laintiffs cannot circumvent this result by claiming that a violation is actionable as [a deceptive practices claim]" because it is contrary to legislative intent and at odds with the statutory scheme).

189. Stop Youth Smoking Addiction, Inc. v. Lucky Stores, Inc., 950 P.2d 1086, 1091 (Cal. 1998) (" $[\mathrm{I}] \mathrm{t}$ is in enacting the UCL itself, and not by virtue of particular predicate statutes, that the Legislature has conferred upon private plaintiffs 'specific power' to prosecute unfair competition claims.").

190. CAL. Bus. \& PROF. CODE $\S 17203$ (West 2004). See also Cortez v. Purolator Air Filtration Prods. Co., 999 P.2d 706, 717 (Cal. 2000) (recognizing the trial court's "very broad" discretion in awarding equitable relief).

191. Fletcher v. Sec. Pac. Nat'1 Bank, 591 P.2d 51, 59 (Cal. 1979).

192. See, e.g., George Avalos, Prop. 64 Draws Strong Arguments, State Measure Would Limit Right to Sue; Backers and Foes Both Predict Calamity If They Lose, CONTA Costa TimeS, Oct. 25, 2004, at 4; David Reyes, Business Owners Rally Around Initiative to Limit Lawsuits; Proposition 64 Aimed at 'Shakedowns,' Would Weaken Unfair Competition Law, L.A. TIMES, Sept. 16, 2004, at B3; Robert Rodriguez, Business Coalition Seeks to Tighten Law, Lawyers Use Loophole to Sue, Group Says, FRESNO BEE, Oct. 6, 2004, at C1.

193. John Wildermuth, Measure Would Limit Public Interest Suits, S.F. Chron., May 31, 2004, at B1.

194. Benson v. Kwikset Corp., 15 Cal. Rptr. 3d 407 (Cal. Ct. App. 2004).

195. Amanda Bronstad, Brar \& Gamulin Nail Salons Sued Under Unfair Competition Law, L.A. BuS. J., Dec. 16, 2002, at 12. 
for it to meet disability requirements. ${ }^{196}$ Plaintiffs sued AOL Time Warner, Disney, and Metro-Goldwyn-Mayer for using movie reviews from critics who received perks for their reviews. ${ }^{197}$ Nike faced a suit when it attempted to defend itself against allegations that it mistreated and underpaid workers in production facilities in Asia brought by a California resident who alleged "no harm or damages whatsoever regarding himself individually."198

On November 2, 2004, public outrage over Section 17200 lawsuits led California voters to overwhelmingly pass Proposition 64, which limited the potential for abuse of Section $17200 .{ }^{199}$ Individuals who have suffered neither a monetary nor a proprietary injury can no longer bring an action under the UCL. ${ }^{200}$ In addition, a private individual who brings a representative action on behalf of others must have suffered an injury and must comply with the requirements for class action lawsuits in California. ${ }^{201}$ Proposition 64's reforms address the most egregious abuses of Section 17200 - frivolous lawsuits by uninjured parties and actions brought by individuals on behalf of others without class action safeguards.

\section{B. Stretching the Law Past its Limits to Attack Deep-Pocket and Unpopular Defendants}

Consumer protection statutes are increasingly used to assert novel, private causes of action against perceived deep-pocket companies and unpopular industries where liability would not ordinarily exist under common law. These lawsuits seek to tempt courts into stretching CPAs to regulate entire industries where legislators or regulators have not acted

196. Rodriguez, supra note 192.

197. John H. Sullivan, California's All-Purpose Plaintiffs' Law Continues to Reach Out, Touch Everyone, 10 METRO. CORP. CounS., Jan. 2002, at 52. In one instance, a Beverly Hills law firm filed more than 2200 claims against restaurants and auto repair shops on behalf of a dummy corporation located at the law firm's address. Monte Morin, State Accuses Law Firm of Extortion, L.A. Times, Feb. 27, 2003, at 5. The claims were based on minor violations of the state's Automotive Repair Act. The law firm sent the defendants settlement offers that demanded payments ranging from $\$ 6000$ to $\$ 26,000$. Id. In early 2003, California Attorney General Bill Lockyer filed a Section 17200 lawsuit on behalf of the state against the law firm involved for abusing Section 17200. Id. Ultimately, the lawyers from the law firm surrendered their law licenses.

198. Nike, Inc. v. Kasky, 539 U.S. 654, 656 (2003).

199. Gareeb, supra note 183.

200. CAL. Bus. \& PROF. CODE $\S 17204$ (West 2004) (as amended by Proposition 64).

201. CAL. Bus. \& PROF. CODE $\S 17203$ (West 2004) (as amended by Proposition 64). 
and to provide large damage awards without a showing of an actual injury or causation. ${ }^{202}$

\section{McLawsuits}

Consumer protection laws have provided the tool by which plaintiffs' lawyers have attacked the fast food industry for America's overeating. ${ }^{203}$ This occurred in Pelman ex rel. Pelman v. McDonald's

202. Altering fundamental tort law to attack an unpopular industry can have extraordinary, unforeseen consequences. For example, in the 1982 product liability case of Beshada v. JohnsManville Products Corp., the New Jersey Supreme Court ruled that an asbestos manufacturer could be held liable even if it did not know or could not have known of a risk caused by its product. 447 A.2d 539, 549 (N.J. 1982). See also Halphen v. Johns-Manville Sales Corp., 484 So. 2d 110, 113 14 (La. 1986) (same). Some commentators attribute rulings of this type, which strip defendants of available defenses, to a quest by courts to expedite asbestos litigation because of the surge in asbestos lawsuits. See Victor E. Schwartz \& Leah Lorber, A Letter to the Nation's Trial Judges: How the Focus on Efficiency Is Hurting You and Innocent Victims in Asbestos Liability Cases, 24 AM. J. TRIAL AdVOC. 247, 264-67 (2000). The New Jersey Supreme Court later limited the damage of its ruling by restricting Beshada's holding to its facts, see Feldman v. Lederle Labs., 479 A.2d 374, 388 (N.J. 1984), and both the New Jersey and Louisiana rulings were later overruled by legislation, see LA. REV. STAT. ANN. § 9:2800.56(1) (1991); N.J. REV. STAT. § 2A:58C-3(3) (1987).

203. Recently, the dairy industry has also faced attack under CPAs. In June 2005, the Physicians Committee for Responsible Medicine (PCRM) filed two lawsuits, a class action seeking injunctive relief and an individual action for damages under Virginia's Consumer Protection Act, against the International Dairy Foods Association, National Dairy Council, and several individual companies. See Complaint, Physicians Comm. for Responsible Med. v. Kraft Foods, Inc., Ch. No. 05-00-2179 (Va. Cir. Ct., City of Alexandria, filed June 28, 2005); Complaint, Physicians Comm. for Responsible Med. v. Int'l Dairy Foods Ass'n, At Law No. 05-0013-20 (Va. Cir. Ct., City of Alexandria, filed June 28, 2005). The complaints allege the defendants falsely advertised milk products as helpful in promoting weight loss. Kraft Foods at 1, Ch. No. 05-00-2179; Int'l Dairy at 1, At Law No. 05-0013-20. The dairy industry has disputed PCRM's claims, stating that "PCRM is an anti-meat, anti-dairy group whose campaigns and views are closely aligned with the animal rights group People for the Ethical Treatment of Animals (PETA)." Press Release, National Dairy Council, Extensive Body of Science Backs Dairy/Weight-Loss Link; Animal Rights Group Once Again Tries to Distort the Facts, http://www.nationaldairycouncil.org/NationalDairyCouncil/Press/ Alert/Alert2005/PCRMstatement62705DairyWeightLoss.htm. (last visited Dec. 2, 2005). The industry's release also states that physicians make up only five percent of PCRM's membership and notes that PCRM's views in the past have been denounced by the American Medical Association and other reputable organizations. Id. "When it comes to nutrition, people should listen to health and nutrition professionals, not an animal rights group." Id. PCRM has also filed a class action lawsuit against supermarket chains and dairy companies under the District of Columbia's CPA on behalf of all District residents who are or may become lactose intolerant for allegedly failing to warn consumers about the effects of lactose. See Plaintiffs' Class Action Complaint, Mills v. Giant of Maryland, Civ. Action No. 05-0008054, at 1-4 (D.C. Sup. Ct., filed Oct 6, 2005) (on file with author). The lactose lawsuit seeks monetary compensation for named plaintiffs and a court order prohibiting the defendants from selling milk in the District until packaging provides a specified warning label about lactose intolerance. See id. at 15-17; see also Marguerite Higgins, Lawsuit Targets Dairy Industry, WASH. TIMES, Oct. 6, 2005, at C8 (reporting that the group plans to file additional lawsuits regarding other dairy products, such as cheese and yogurt, depending on the success of the milk claim). 
Corp. ${ }^{204}$ a case by two minors through their parents against the burger giant under the New York Consumer Protection Act (NYCPA), which prohibits deceptive acts or practices and false advertising. ${ }^{205}$ The lawsuit was brought as a class action on behalf of all minors living in New York state who had purchased and consumed McDonald's products. ${ }^{206}$ The plaintiffs alleged that McDonald's led them to believe its products were "healthy and wholesome" and to purchase McDonald's products in a manner they otherwise would not have. ${ }^{207}$ The plaintiffs claimed their consumption of McDonald's products led to an increased likelihood of a plethora of adverse health effects, ranging from obesity to high blood pressure, heart disease, and cancer. ${ }^{208}$

Federal District Court Judge Robert Sweet wrote two lengthy opinions dismissing the lawsuit. ${ }^{209}$ In his first ruling, Judge Sweet recognized that traditional showings of reliance and scienter were not required under the NYCPA but that the deceptive practice must be objectively misleading to the reasonable consumer. ${ }^{210}$ He nevertheless initially dismissed the claims because the plaintiffs did not identify a single instance of McDonald's committing a deceptive act and because it was not unlawful to encourage consumers to purchase a product. ${ }^{211}$ Judge Sweet also found that the plaintiffs had "shunned" their duty to show why the failure of McDonald's to label its food with nutritional information, an obligation not required by state or federal regulations, was deceptive. $^{212}$

After the plaintiffs amended their complaint to cure the deficiencies identified in the court's dismissal of the case, Judge Sweet again

204. 237 F. Supp. 2d 512, 519-20 (S.D.N.Y. 2003), vacated in part and remanded, 396 F.3d 508 (2d Cir. 2005).

205. N.Y. GEN. BUS. LAW $\S \S 349-50$ (McKinney 2004).

206. Pelman, 237 F. Supp. $2 \mathrm{~d}$ at 520.

207. Pelman, 396 F.3d at 510. Specifically, the plaintiffs alleged that McDonald's violated Sections 349 and 350 because (1) "the combined effect of McDonald's various promotional representations... was to create the false impression that its food products were nutritionally beneficial and part of a healthy lifestyle if consumed daily;" (2) "McDonald's failed adequately to disclose that its use of certain additives and the manner of its food processing rendered certain of its foods substantially less healthy than represented;" and (3) "McDonald's deceptively represented that it would provide nutritional information to its New York customers when in reality such information was not readily available." Id.

208. Id.

209. See Pelman, 237 F. Supp. 2d at 512; Pelman ex rel. Pelman v. McDonald's Corp., No. 02 Civ. 7821(RWS), 2003 WL 22052778 (S.D.N.Y. Sept. 3, 2003), vacated in part, 396 F.3d at 508.

210. Pelman, 237 F. Supp. 2 d at 525.

211. See id. at 527-28 ("Merely encouraging consumers to eat its products 'everyday' is mere puffery, at most, in the absence of a claim that to do so will result in a specific effect on health.").

212. Id. at 529 . 
dismissed the complaint, this time without leave to amend. ${ }^{213}$ First, the court addressed the lack of any showing of reliance - as the plaintiffs did not claim they had ever seen or heard a McDonald's advertisement. ${ }^{214}$ The court found that NYCPA did not require a showing of reliance when claiming a deceptive act but that reliance was required in a claim for false advertising. ${ }^{215}$ Finding that the plaintiffs were "not entitled to a presumption of reliance" 216 and that the plaintiffs" vague allegations of reliance on unspecified advertisements were insufficient, the court dismissed the false advertising claims. ${ }^{217}$ The court then dismissed the deceptive practices claim because of the lack of any showing of causation between the McDonald's food consumed and the alleged injuries. ${ }^{218}$ "Plaintiffs have failed... to draw an adequate causal connection between their consumption of McDonald's food and their alleged injuries," the court found, given their consumption of other types of food and other behaviors, beyond diet, that could factor into the plaintiffs' obesity and other health problems. ${ }^{219}$ In addition, the court found that the plaintiffs had not shown that an objectively reasonable consumer would have been misled by the defendant's assertions with respect to the preparation and content of french fries and hash browns. ${ }^{220}$

In January 2005, the United States Court of Appeals for the Second Circuit vacated the district court's ruling. ${ }^{221}$ While the district court's dismissal of the deceptive advertising claim (which required a showing of reliance) went unchallenged, the appellate court reinstated the deceptive practices claim. ${ }^{222}$ The court found that a claim under the consumer protection statute "need only meet the bare-bones noticepleading requirements" of the Federal Rules of Civil Procedure and that it did not need to be pled with particularity, as in common law fraud actions. ${ }^{223}$ For this reason, the Second Circuit found that causation issues were appropriate for discovery and that the plaintiffs' claims should not have been dismissed prior to such an opportunity. ${ }^{224}$

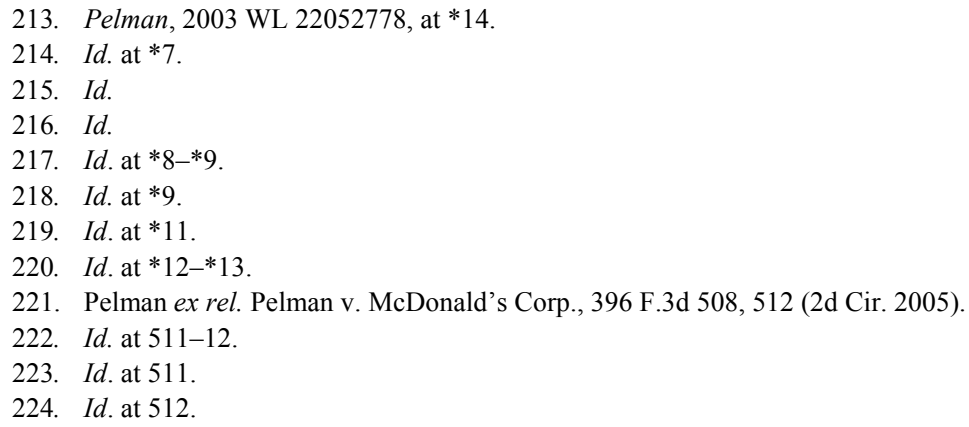


Pelman provides a vivid illustration of the importance of requiring actual reliance and causation in consumer protection claims. The alternative is to permit plaintiffs' lawyers to bring class action lawsuits claiming (1) information either should or should not have been provided to consumers; (2) even though those allegedly injured never saw or heard or relied upon the information; and (3) where the tie between the advertisement or practice and the injury is obviously lacking. While this case may ultimately be dismissed a third time, the Second Circuit's decision permits the plaintiffs to engage in a fishing expedition in which McDonald's will go through lengthy and costly discovery. The company will have increased pressure to settle, regardless of the legal merits, particularly if the court later certifies the class. Finally, Pelman presents an example of how consumer protection statutes can be used to impose "regulation through litigation," by which some plaintiffs" lawyers attempt to regulate entire industries in ways not contemplated by those empowered to do so-legislatures and regulatory agencies. ${ }^{225}$

\section{2. "Lights" Lawsuits}

After receiving billions in attorneys' fees as a result of the multi-state settlement of lawsuits aimed at forcing the industry to pay for smokingrelated health costs incurred through Medicaid, ${ }^{226}$ the legal industry built around such suits needed a new way to attack the unpopular tobacco companies. Class action lawsuits asserting claims under consumer protection statutes provided this new tool. The latest innovation, socalled "lights cases," generally involve allegations that cigarette manufacturers violated CPAs by misleading smokers into believing light cigarettes were safer and less harmful than regular cigarettes. ${ }^{227}$ The first

225. See generally Victor E. Schwartz \& Leah Lorber, Regulation Through Litigation Has Just Begun: What You Can Do To Stop It, Briefly, Nov. 1999, vol. 3, No. 11, available at http://www.nlcpi.org/books/pdf/Vol3Num11Nov1999.pdf (stating that some judges and lawyers attempt to usurp the power of elected representatives). Twenty states have reacted by enacting legislation prohibiting lawsuits against food manufacturers and sellers arising out of weight gain, obesity, a health condition associated with weight gain or obesity, or other generally known conditions allegedly caused by or allegedly likely to result from long-term consumption of food. See Melanie Warner, The Food Industry Empire Strikes Back, N.Y. TIMES, July 7, 2005, at C1 (citing the victories of fast food companies in avoiding law suits); see also Victor E. Schwartz \& Phil S. Goldberg, Closing the Food Court: Why Legislative Action is Needed to Curb Obesity Lawsuits, BRIEFLY, Aug. 2004, vol. 8, No. 8, available at http://www.nlcpi.orgbooks/pdf/BRIEFLY_Aug04. pdf (discussing an overview of litigation against food companies).

226. See Elaine McArdle, Trial Lawyers, AGs Creating a New Branch of Government, LAw. WKLY. USA, July 12, 1999, at B3 (discussing the rise of industry-wide lawsuits).

227. Light cigarettes include ventilation holes near the cigarette's filter, which reduce the delivery of tar and nicotine. In claims under CPAs, plaintiffs allege that when consumers smoke the 
of these suits was filed in 1998, not coincidently the same year the tobacco industry agreed to the landmark \$246-billion settlement with state attorneys general in the Medicaid recoupment suits. Several courts have heard cases alleging identical facts and have come to very different conclusions, illustrating the clear choice that judges have in interpreting CPAs. ${ }^{228}$

Tobacco companies argue that class certification is improper and that liability in these cases is unsupported because consumers purchase the product for different reasons, use it in different ways, and cannot show actual financial loss. They note that a substantial number of smokers purchase light cigarettes for their taste, rather than for any perceived health benefit. ${ }^{229}$ In addition, depending on the manner in which the cigarette is smoked, some consumers receive lower tar and nicotine than they would when smoking regular cigarettes. ${ }^{230}$ The companies argue that because the cost of light cigarettes is no higher than regular cigarettes, the plaintiffs "lost" nothing. ${ }^{231}$

In the August 2004 ruling in Aspinall v. Philip Morris Co., a sharply divided Supreme Judicial Court of Massachusetts (the highest court in the Commonwealth) affirmed a trial court order certifying a class consisting of all purchasers of Marlboro Lights in Massachusetts. ${ }^{232}$

cigarettes they often cover the ventilation holes with their lips or fingers or increase the frequency and volume of puffs to compensate for lower nicotine levels, which diminishes or eliminates any health benefit. The plaintiffs seek damages for the economic injury of purchasing a product that differs from what tobacco companies represent it to be. See, e.g., Philip Morris USA, Inc. v. Hines, 883 So. 2d 292, 293 (Fla. Dist. Ct. App. 2004); Aspinall v. Philip Morris, Inc., 813 N.E.2d 476, 48081 (Mass. 2004).

228. As of the time of this writing, "lights" cases are certified as class actions only in Missouri and Ohio. See Collora v. R.J. Reynolds Co., No. 002-00732, 2003 WL 23139377 (Mo. Cir. Ct., Dec 31, 2003); Craft v. Philip Morris Cos., No. 002-00406A, 2003 WL 23139381 (Mo. Cir. Ct., Dec 31, 2003); Marrone v. Philip Morris USA, Inc., No. 03CA0120-M, 2004 WL 2050485 (Ohio Ct. App., Sep 15, 2004) (affirming the trial court's certification of an Ohio Consumer Sales Practices Act claim and denial of certification of fraud claims seeking compensation for personal injuries), appeal allowed, 821 N.E.2d 1026 (Ohio 2005). The Missouri and Ohio cases are on appeal.. On the other hand, several courts have refused to certify "lights" cases. In January 2005, a Minnesota court denied class certification in a lights case after finding that individual issues predominated. See Shook, Hardy, \& BACON L.L.P., The TREnd Rejecting CERTIFICATION of Tobacco Class ACTIONS 46 (2004) (citing Curtis v. Philip Morris Cos., No. PI 01-018042, slip op. (Minn. Dist. Ct., Hennepin County, Jan. 16, 2004)). In March 2005, a California court decertified a lights class action after finding that the November 2004 referendum of California's Section 17200, discussed above, negated class action status. Brown v. Am. Tobacco Co., No. JCCP 4042, 2005 WL 579720 (Cal. Super. Ct., Mar. 7, 2005).

229. See, e.g., arguments raised in cases cited supra note 228.

230. See, e.g., Aspinall, 813 N.E.2d at 486 (citing plaintiff's admission that some people received lower tar and nicotine).

231. See, e.g., Philip Morris USA, Inc. v. Hines, 883 So. 2d 292, 293-94 (Fla. Dist. Ct. App. 2004) (stating smokers received what they paid for); Aspinall, 813 N.E.2d at 486 (same).

232. 813 N.E.2d at 492 . 
Finding class certification proper, the four-member majority rejected the defendant's argument that each member of the class must prove the allegedly deceptive advertising caused actual harm. ${ }^{233}$ Rather, the majority found that a practice was deceptive-thus, actionable under Massachusetts's CPA as a class action - if it was capable of misleading a reasonable consumer. ${ }^{234}$ "Neither an individual's smoking habits nor his or her subjective motivation in purchasing Marlboro Lights bears on the issue of whether the advertising was deceptive," the court found. ${ }^{235}$ With respect to damages, the majority found that even if the class could not prove actual damages because Marlboro Lights were the same price as regular cigarettes, each member of the class would be entitled to statutory damages of $\$ 25$ under the CPA. ${ }^{236}$ According to the court, an invasion of the legal right created by the CPA constitutes an injury in itself, regardless of whether the consumer experienced an economic loss. $^{237}$

Interpreting the same law, three dissenting judges reached the opposite conclusion. ${ }^{238}$ The dissent recognized that " $[t]$ he requirement that the plaintiffs demonstrate an 'injury' may not be shrugged off lightly" and that a plaintiff cannot recover even nominal damages without making such a showing. ${ }^{239}$ The dissent found it was impossible for the plaintiffs to meet the "similar injury" requirement necessary for class certification under the statute because the plaintiffs conceded some class members actually did receive lower levels of tar and nicotine and, thus, were not harmed. ${ }^{240}$ The dissent concluded that, by certifying a class including uninjured members, the majority effectively permitted a "purely 'vicarious suit[] by self-constituted private attorneysgeneral." "241

Other courts have followed reasoning similar to the dissenting judges in Aspinal and refused to certify class actions in lights cases. In Philip Morris USA Inc. v. Hines, a Florida appeals court interpreting Florida's

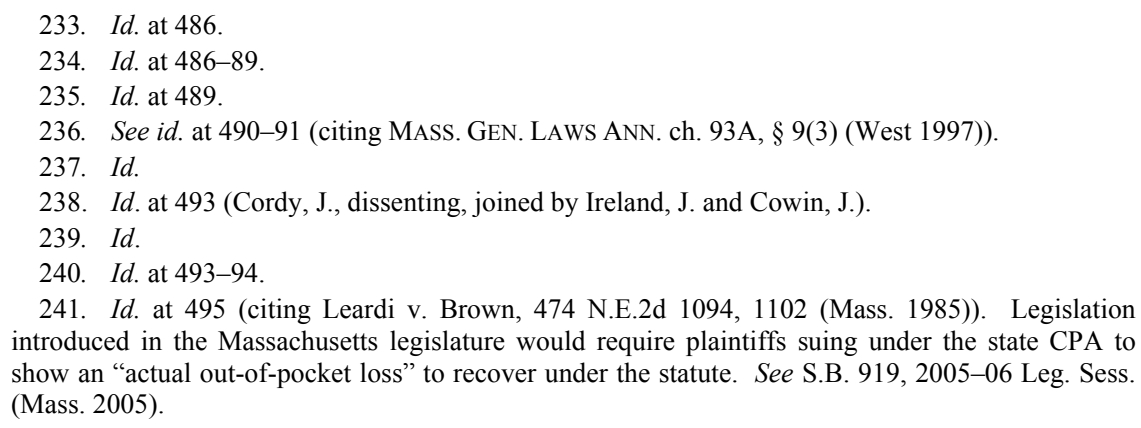


Deceptive and Unfair Trade Practices Act (FDUTP) ${ }^{242}$ reversed a lower court's class certification. $^{243}$ In a per curiam opinion, the Florida court recognized that "despite a common nucleus of facts concerning a prospective class-action-defendant's conduct, a lawsuit may present individualized plaintiff-related issues which make it unsuitable for class certification." 244 The court found that the manner in which each class member smoked light cigarettes affected whether that member "reaped" the benefits of a cigarette with lower tar and nicotine. ${ }^{245}$ The court also recognized that some smokers may have purchased lights for their distinctive taste and not because of any perceived health value. ${ }^{246}$ These issues "could preclude an individual smoker's entitlement to damages and, thus, would be legitimate issues raised in defense."247

Plaintiffs' lawyers who file class actions can recover enormous sums of money without showing actual damages because many CPAs provide statutory damages. While individual class members may only recover $\$ 25$ under the Massachusetts statute, ${ }^{248}$ plaintiffs' lawyers stand to recover contingency fees based on a percentage of the \$25 recovered for every smoker of light cigarettes in the state. Unless judges interpret state CPAs with caution, plaintiffs' lawyers will continue to exploit CPAs to attack unpopular companies for hypothetical injuries without providing any real benefit to society. ${ }^{249}$

In 2003, a lights case resulted in the largest verdict in Illinois history-a \$10.1-billion bench verdict against Philip Morris in Madison County, Illinois. The verdict included $\$ 7.1$ billion in compensatory damages, $\$ 1.77$ billion of which was allocated for payment of attorneys' fees, and $\$ 3$ billion in punitive damages paid to the State of Illinois. ${ }^{250}$

\footnotetext{
242. Fla. StAT. ANN. § 501.211(2) (West 2002).

243. 883 So. 2d 292, 295 (Fla. Dist. Ct. App. 2003).

244. Id. at 294 .

245. Id.

246. Id. at $293-94$.

247. Id. at 294.

248. MASS. GEN. LAwS ANN. ch. 93A, § 9(3)(4) (West 1997).

249. For instance, the McLawsuit and lights cases recently intersected in a California lawsuit. Lawyers, perhaps inspired by the use of CPAs to attack the fast food industry for obesity-related ailments and light cigarettes, have found a new target: breakfast cereal manufacturers. In March 2005, a California plaintiff brought a class action lawsuit on behalf of all consumers who had purchased "low-sugar" cereals against Kraft Foods, General Mills Cereals, and Kellogg USA, along with a local retailer. Complaint, Hardee v. Del Mission Liquor, No. 844745 (Cal. Sup. Ct., filed Mar. 24, 2005) (on file with authors). The plaintiffs claimed that cereals advertised as low in sugar falsely represented that they were more nutritious than their "full-sugar" counterparts. Id. The complaint included a claim under California's Unfair Competition Law, Section 17200, and sought a permanent injunction, restitution, and attorneys' fee and costs. $I d$.

250. Price v. Philip Morris, Inc., No. 00-L-112, 2003 WL 22597608, at*29-30 (Ill. Cir. Ct. Mar.
} 
The class in Price v. Philip Morris, Inc., involved all consumers who purchased light cigarettes in Illinois during a thirty-year period. ${ }^{251}$ In December 2005, a closely divided Illinois Supreme Court overturned the judgment, but on grounds unrelated to the appropriateness of class certification. $^{252}$ First, the court closely examined federal regulation of light cigarettes during the past thirty-five years, including the FTC entrance into consent orders with the industry allowing manufacturers to use the terms "low," "lower," "reduced" tar, or "light" so long as all packaging and advertising included disclosure of tar and nicotine levels based on a federally specified testing method. ${ }^{253}$ The majority then found that the Illinois Consumer Fraud Act's exception to actions or transactions specifically authorized by laws administered by any state or federal regulatory body or officer applied to bar the claim. ${ }^{254}$ It is important to note that the court's decision was not based on federal preemption but rather on an interpretation of its own state consumer protection statute and recognition of "a legislative policy of deference to the authority granted by Congress or the General Assembly to federal and state regulatory agencies and a recognition of the need for regulated actors to be able to rely on the directions received from such agencies without risk that such reliance may expose them to tort liability."255 The court also recognized that when a government agency regulates conduct, objections to that policy are appropriately made through the political process, not in the courts. ${ }^{256}$ Finally, in dicta, the majority questioned the appropriateness of class certification given not only the requirement that each individual member show that he or she was actually deceived by the defendant's representations and that the advertising and not other motivators caused the purchase, but also the differences in the ways class members actually smoked the cigarettes. ${ }^{257}$

21, 2003), overruled on other grounds, 793 N.E.2d 942 (Ill. App. Ct. 2003), vacated, No. 96644, 2003 Ill. LEXIS 2625 (Ill. Sept. 16, 2003).

251. Id. at $* 1$.

252. See Price v. Philip Morris, No. 96326, 2005 WL 3434368 (Ill. Dec. 15, 2005).

253. See id. at *1-14.

254. See id. at *31-45. The Illinois Consumer Fraud Act provides that it shall not apply to actions "specifically authorized by laws administered by any regulatory body or officer acting under statutory authority of this State or the United States." 815 ILL. COMP. STAT. ANN. 505/10b(1) (West 1998).

255. Price, 2005 WL 3434368 , at $* 34$.

256. Id. The court's decision demonstrates its rejection of the much-criticized process of "regulation through litigation." See generally Schwartz \& Lorber, supra note 225.

257. See id. at *46-48; see also id. at*50-55 (Karmeier, J., specially concurring) (finding that the named plaintiffs could not show actual damages and examining the fundamental flaws in the damages methodology accepted by the circuit court). 
The Price decision, and the split between members of the Illinois Supreme Court, again shows the fundamental choices available to courts in interpreting CPAs. In addition, although the momentous award was ultimately overturned, plaintiffs' lawyers may still look to the lower court ruling and the dissent in the Illinois Supreme Court to bring CPA lawsuits against "unpopular" industries. Finally, the Price decision may increase the importance of statutory exemptions for conduct approved or authorized by federal or state government agencies. Most CPAs include an exemption similar to that contained in the Illinois law, ${ }^{258}$ and their impact can extend well beyond light cigarette cases to other states and other products and services provided by highly regulated industries.

\section{Blaming Alcoholic Beverage Advertisements for Illegal Underage Drinking}

During the past two years, the alcoholic beverage industry has joined the tobacco industry as a popular target under CPAs. In several states, lawyers have brought class actions against the industry alleging that its advertising induces teenagers to illegally buy and drink alcoholic beverages. $^{259}$ The lawsuits seek disgorgement of the industry's profits and statutory, treble and punitive damages, and attorneys' fees, where available. In lawsuits inspired by state attorneys general against the cigarette companies, private lawyers allege that alcoholic beverage manufacturers violated CPAs by marketing their products to young people, including those under the legal drinking age. ${ }^{260}$ According to the complaints, the companies marketed their products to young consumers by producing malt-flavored beverages referred to by the plaintiffs as "alco-pops," by featuring youthful models and partying in advertisements, and by placing advertisements in magazines and television shows that include a young audience. ${ }^{261}$ These lawsuits have sometimes arisen from tragedies in which an under-age drunk driver

258. See supra note 160.

259. See, e.g., Complaint, Goodwin v. Anheuser-Busch Cos. \& Miller Brewing Co., No. BC310105 (Cal. Super. Ct., L.A., filed Feb. 3, 2004); Complaint, Kreft v. Adolph Coors Co., No. 03-CV-9229 (Colo. Dist. Ct., City \& County of Denver, filed Dec. 3, 2003); Complaint, Hakki v. Zima Co., No. 03-CV-2621-GK (D.C. Super. Ct., filed Nov. 13, 2003); Complaint, Tomberlin v. Adolph Coors Co. No. 2005CV000545 (Wis. Cir. Ct., Madison, filed Feb. 23, 2005).

260. See Molly McDonough, Battle Over Liquor Just Beginning: One Suit is Dismissed, But Four Others Try to Link Ads and Kids, 4 ABA J., Feb. 11, 2005 (eReport on file with the KANSAS LAW REVIEW).

261. See arguments raised in cases cited supra note 259. 
killed an individual, ${ }^{262}$ but plaintiffs do not seek compensation for these injuries. Rather, the lawsuits seek to recover on behalf of all parents whose under-age children purchased alcoholic beverages over a period of two decades, a class estimated to include thousands of people.

A California court dismissed the first of these cases to reach a decision in late 2004 and early $2005 .^{263}$ In the first of two rulings, in December 2004, Los Angeles Superior Court Judge Peter D. Lichtman dismissed a claim under California's Unfair Competition Law, Section 17200. Judge Lichtman found that the plaintiffs failed to allege actual loss of money or property as required by Proposition $64 .^{264}$ The following month, Judge Lichtman dismissed the plaintiffs' remaining claims, including a claim under California's Consumer Legal Remedies Act, which prohibits representing that goods or services have characteristics that they do not have. ${ }^{265}$ Judge Lichtman ruled that regulating alcohol advertisements was not within the jurisdiction of the courts but was the job of the Department of Alcoholic Beverages Control. ${ }^{266}$ Judge Lichtman also found that the plaintiffs did not identify any advertising that was misleading or false but focused on "puffery or on qualities that are not affirmations of fact such as the fun, sexiness, popularity, social acceptance, athleticism, etc. that drinking alcohol can bring." 267 The dismissal is on appeal. ${ }^{268}$

262. See, e.g., Goodwin, No. BC310105 (parents sued after an eighteen-year-old drunk driver killed their daughter).

263. See Ruling on Motion for Judgment on the Pleadings, Goodwin v. Anheuser-Busch Cos. \& Miller Brewing Co., No. BC310105 (Cal. Super. Ct. L.A., ruled Dec. 13, 2004).

264. See Myron Levin, Lawsuits Take Aim at Ads for Alcohol, L.A. TIMES, Jan. 27, 2005, at C1 (discussing Ruling on Motion for Judgment on the Pleadings, Goodwin, No. BC310105).

265. See CAL. CIV. CODE $\S 1770(a)(5)$ (West 1998). The California Consumer Legal Remedies Act is more narrowly confined than the state's Unfair Competition Law, Section 17200, and is similar to other state CPAs.

266. See Ruling on Motion for Judgment on the Pleadings, at 6-7, Goodwin, No. BC310105.

267. Id. at 11. First Amendment issues aside, the lawsuits against the alcoholic beverage industry for underage drinking defy fundamentals of tort law because plaintiffs cannot show that their children saw the advertisements, much less that the advertisements caused them to make a purchase. In addition, plaintiffs do not assert any individual injury. Instead, they seek disgorgement, a questionable remedy under CPAs given that unlike restitution, which requires a defendant to return money obtained through an unfair business practice to those from whom the property was taken, disgorgement is simply a taking of the defendant's profits, with no showing of actual consumer loss. Moreover, these lawsuits allege harms to society generally, a policy issue more appropriately considered by Congress, should it wish to further regulate the industry.

268. Likewise, a Colorado trial court dismissed a similar claim under the Colorado Consumer Protection Act in September 2005. See Order of Court, Kreft v. Zima Beverage Co., No. 04CV1827 (Colo. Dist. Ct., Jefferson County, Sept. 16, 2005) (on file with authors). The Colorado trial court found that the plaintiffs lacked standing because they failed to show a legally cognizable injury to themselves or their children. See id. The dismissal in Kreft is on appeal. 
4. Pharmaceutical Manufacturers: Failure to Disclose Alleged Product Defects as a Deceptive Act

Pharmaceutical companies are also seeing their share of CPA litigation despite the Food and Drug Administration's rigorous regulation of drug advertising. One example is In re West Virginia Rezulin Litigation $v$. Hutchinson. ${ }^{269}$ That case is a consolidation of several lawsuits filed by plaintiffs who used the FDA-approved drug Rezulin, a diabetes medication, which plaintiffs alleged caused liver damage in some patients. ${ }^{270}$ The plaintiffs argued that manufacturers aggressively and falsely marketed the drug as having breakthrough effectiveness with low side effects. ${ }^{271}$ Among their product liability claims, the plaintiffs, who used the drug but did not have signs of harm, included an action under the West Virginia Consumer Credit and Protection Act (WVCCPA). ${ }^{272}$ The plaintiffs alleged the manufacturers committed a deceptive practice by not disclosing to consumers problems with the drug. ${ }^{273}$ Noting that it had never examined the WVCCPA in detail, the court went on to hold that the statutory requirement that a plaintiff show an "ascertainable loss" did not require a showing of actual damages. ${ }^{274}$ While recognizing the WVCCPA "is not designed to afford a remedy for trifles," the court found that the plaintiffs needed only to allege that they received a product that was different or inferior to that which they believed they purchased. ${ }^{275}$ Thus, West Virginia's high court overturned the intermediate appellate court and certified the case. ${ }^{276}$

More recently, a law firm filed a class action lawsuit on behalf of more than 150,000 Kentucky residents who took the popular arthritis drug Vioxx. ${ }^{277}$ The plaintiffs claimed that the manufacturer, Merck \& Co., violated the CPA by advertising the drug to the public as safe without fully disclosing its known side effects. ${ }^{278}$ The plaintiffs are seeking damages up to $\$ 75,000$ (to avoid federal diversity jurisdiction)

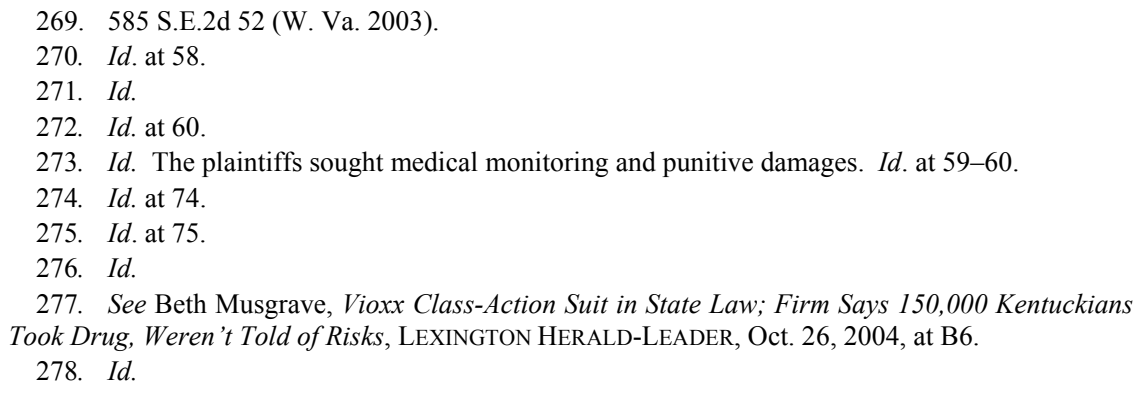

277. See Beth Musgrave, Vioxx Class-Action Suit in State Law; Firm Says 150,000 Kentuckians Took Drug, Weren't Told of Risks, LeXINGTON HERALD-LEADER, Oct. 26, 2004, at B6. 
for each Kentucky resident who used the drug. ${ }^{279}$ Unlike product liability lawsuits filed against Merck in other states, ${ }^{280}$ both the Kentucky suit and a similar suit in Oklahoma were brought under the states' CPAs. ${ }^{281}$ This allowed plaintiffs' lawyers in Kentucky to sue on behalf of a class of individuals who did not experience any physical injury but merely purchased the drug. ${ }^{282}$ Those cases are ongoing as of the time of this writing. ${ }^{283}$

\section{COMMON-SENSE CONSTRUCTION By COURTS OF CONSUMER PROTECTION ACTS}

The history of states interpreting and applying CPAs demonstrates that courts often wield a great deal of power in shaping private rights of action under the law. As this Article has shown, most statutes require some degree of causal connection between a violation of the CPA and an injury, but few address the other fundamental elements of torts, such as reliance, intent, and damages. ${ }^{284}$ CPAs may also lack a trigger for an award of treble damages or attorneys' fees, and they may fail to address the availability of class action relief under the law's already generous provisions. ${ }^{285}$ Courts can allow use of their state's CPA to attack what may be lawful conduct in other states, or they can limit application of the

279. Id.

280. The first Vioxx case to go to trial resulted in a $\$ 253.5$-million award, $\$ 24.5$ million in economic damages and \$229 million in punitive damages, to a single plaintiff. Alex Berenson, Jury Calls Merck Liable in Death of Man on Vioxx, N.Y. TIMES, Aug. 20, 2005, at A6. The product liability lawsuit involved a man who died of cardiac arrhythmia, a condition not previously linked to Vioxx. Richard Stewart, Legal Armies Set to Wage Big-Dollar Vioxx Battle; Lawsuit's Cost Likely to Run into Millions of Dollars, Houston CHRON., July 18, 2005, at B1. Under Texas law, which places caps on punitive damages, the $\$ 229$ million punitive damage award must be reduced to $\$ 1.6$ million, putting the total award at \$26.1 million. Berenson, supra. Merck has indicated that it will appeal the verdict. Following the Texas verdict, a New Jersey jury found Merck not liable in another Vioxx case. See Alex Berenson, Merck is Winner in Vioxx Lawsuit on Heart Attack, N.Y. Times, Nov. 4, 2005, at A1.

281. See Musgrave, supra note 277; see also Complaint, House v. Merck \& Co., No. 04-1235 (W.D. Okla., filed Sept. 30, 2004), available at http://www.federmanlaw.com/pdf/CompHouse.pdf (alleging violations of the Oklahoma Consumer Protection Act and Oklahoma Deceptive Trade Practices Act in addition to product liability, negligence, and breach of implied warranty claims).

282. See Merck \& Co.: Getty \& Mayo Lodges Consumer Fraud Lawsuit in KY, IBL CLASS ACTION REP., Oct. 2004, vol. 6, No. 213, available at http://bankrupt.com/CAR_Public/041027.mbx ("We are not seeking compensation for personal injury in this suit.").

283. See Jurisdiction \& Procedure: Vioxx Claims Against Merck are Remanded to State Court, BNA Antitrust \& TRAdE REG. ReP., Mar. 2005, vol. 88, No. 2197 (reporting that the Kentucky case was removed from the Circuit Court for Pike County but then remanded to state court by the federal court).

284. See supra Part III.A.

285. See supra Part III.B-C, E. 
law to protect their citizens from conduct within their jurisdiction. These are all areas where courts, recognizing the difference between government enforcement to protect the public and private litigation, can interpret the law to keep it true to its public purpose and protect its broad provisions from abuse.

\section{A. Requiring Injury in Fact}

Perhaps the most basic requirement to bringing a lawsuit is that the plaintiff suffer some injury. Apart from a showing of wrongful conduct and causation, proof of actual harm to the plaintiff has been an indispensable part of civil actions. ${ }^{286}$ As the Supreme Court of the United States has recognized for purposes of standing in the appellate context, "injury in fact" requires "more than an injury to a cognizable interest. It requires that the party seeking review be himself among the injured." 287 Despite the broad language of CPAs that provide a cause of action to "any person" for violations of the act, and legislative instructions that such statutes be construed liberally, courts should not disregard the threshold issue of standing.

For example, despite vague statutory language, the Colorado Supreme Court has properly required "(a) injury in fact; (b) to a legally protected interest." ${ }^{288}$ The court rejected a claim that literally anyone could bring a lawsuit under the Colorado Consumer Protection Act (CCPA) and noted that it was injury in fact and causation that distinguished private actions from those brought by the Attorney General. $^{289}$ Even a dissenting justice understood that although the CCPA "does not on its face require that a plaintiff prove injury in order to bring a claim," a literal interpretation of the statute "would violate constitutional standing principles because a plaintiff could sue for damages without having suffered an injury. $" 290$

In Williams v. Purdue Pharma Co., a federal court interpreting the District of Columbia's Consumer Protection Procedures Act (DCCPPA) came to a similar conclusion. ${ }^{291}$ In that case, patients prescribed

\footnotetext{
286. For example, most courts that have recently considered the availability of lawsuits for medical monitoring in the absence of a present physical injury have rejected such claims. See Victor E. Schwartz et al., Medical Monitoring: The Right Way and the Wrong Way, 70 Mo. L. REv. 349, 361 (2005).

287. Sierra Club v. Morton, 405 U.S. 727, 734-35 (1972).

288. Hall v. Walter, 969 P.2d 224, 235 (Colo. 1998) (en banc).

289. Id. at 236 .

290. Id. at 240 (Kourlis, J., dissenting).

291. 297 F. Supp. 2d 171, 177-78 (D.D.C. 2003).
} 
OxyContin, a medication for chronic pain relief, brought a class action lawsuit against pharmaceutical manufacturers for deceptive advertising in promoting the drug. ${ }^{292}$ The plaintiffs sought statutory penalties, treble damages, and punitive damages. ${ }^{293}$ The court was faced squarely with the question of "whether patients who were prescribed a drug for pain, and who personally suffered no ill effects or lack of efficacy, can sue for money damages" under the DCCPPA. ${ }^{294}$ The plaintiffs alleged that the manufacturer over-promoted the drug as providing "smooth and sustained" pain relief for twelve hours with little chance of addiction, which allowed the manufacturer to artificially inflate its prices. ${ }^{295}$ Yet, the plaintiffs specifically excluded from the class "all patients who failed to receive 12-hour relief from OxyContin and/or who had problems with it alleged addictive qualities," recognizing that the failure to exclude such groups would result in a product liability lawsuit, not a consumer protection action. $^{296}$ Instead, the class included only those who simply purchased the allegedly overpriced drug. ${ }^{297}$

After reaffirming that only consumers actually harmed can recover through tort law, the court considered the "more difficult question" of whether an individual could recover under the district's consumer protection statute when the alleged injury was a higher price caused by the defendant's promotional tactics. ${ }^{298}$ Unlike the West Virginia court in the Rezulin case, ${ }^{299}$ the federal court rejected this "fraud on the market theory," finding that "[s]tanding requires 'individualized proof' of both the fact and extent of the injury." 300 "The court summarized its reasoning for dismissing the complaint: "While [the complaint] asserts that defendants engaged in false and misleading advertising, it does not plead that these defendants [sic] were in any way deceived — or even saw — any of that advertising. It also fails to allege any particularized and specific injury-in-fact suffered by these plaintiffs." ${ }^{, 101}$ The court advised the plaintiffs that, should they wish to pursue consumer protection violations before people are injured, the proper forum is to go through the government's administrative procedure for enforcement of the

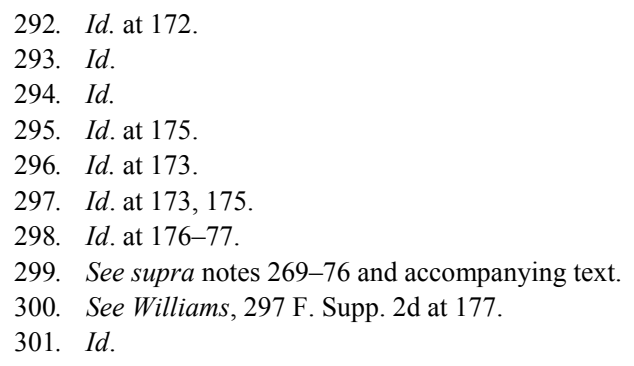


DCCPPA. ${ }^{302}$ "The invasion of a purely legal right without harm to the consumer - in this case to freedom from alleged false and misleading advertising - can be addressed through the administrative process of the Government of the District of Columbia." ${ }^{303}$ Regulation through civil liability suits is both unwarranted and unnecessary where an administrative governmental process is in place.

\section{B. Requiring Reasonable Reliance}

The need to show reliance is an issue not addressed by most state statutes, which allow for judicial interpretation in light of legislative intent, fundamentals of tort law, and public policy. Courts should require plaintiffs asserting CPA claims to show that they actually and reasonably relied on the allegedly deceptive representation.

While state attorneys general should be able to stop deceptive conduct by obtaining injunctive relief against a business before consumers are misled, individuals who never saw, heard, or relied upon the conduct that allegedly injured them should not be able to bring imaginary claims. If the allegedly deceptive conduct did not influence the plaintiff by affecting his or her decision to purchase the product, there should be no private right of action. To do otherwise would eviscerate the fundamental distinction between private rights of action, which are based on harm to an individual, and public enforcement of a law, which may not be. The Supreme Court of the United States recently reaffirmed that the foundation of statutory rights of action for fraud requires justifiable reliance and "has long insisted that a plaintiff in such a case show . . . that had he known the truth he would not have acted." ${ }^{304}$

There is a strong public-policy basis for confining misrepresentation and concealment claims to cases involving actual, material reliance. The alternative is to create a broad cause of action allowing members of the general public to sue based on purported misinformation they did not hear or omissions they did not act upon. Such a course would broadly expand potential liability and free it from the common-sense bounds developed over centuries recognizing the distinction between public and private rights of action. The elimination of actual reliance and other "self-limiting principles" of common law actions could also chill free

\footnotetext{
302. Id. at 178 .

303. Id.

304. Dura Pharm., Inc. v. Broudo, 125 S. Ct. 1627, 1632 (2005) (considering the common law roots of a private right of action for securities fraud).
} 
Speech, raising serious First Amendment concerns, as Solicitor General Theodore B. Olson has argued to the Supreme Court. ${ }^{305}$

Courts should look to the common-sense rulings by the high courts of Kansas and Pennsylvania for guidance and wisdom. For example, in Finstad v. Washburn University, a group of college students brought an action seeking civil penalties for a violation of the Kansas Consumer Protection Act (KCPA) alleging that the university falsely stated in its catalogue that it was accredited or approved by the National Shorthand Reporters Association. ${ }^{306}$ The students conceded that they had not relied on this statement in enrolling in the program and that many, if not all, of them were unaware of it. ${ }^{307}$ Nevertheless, the students claimed they were "aggrieved," in the words of the KCPA, because they paid tuition for a program that was not accredited. ${ }^{308}$ The Kansas Supreme Court affirmed the trial court's dismissal of the claim on summary judgment. ${ }^{309}$ The court noted that although a loss or injury was not required in an action by the Attorney General, in a private lawsuit, it would "not interpret an aggrieved consumer to be one who is neither aware of nor damaged by a violation of the Act." ${ }^{310}$ In other words, those individuals who were neither aware of nor damaged by an actor's violation could not recover. Common sense was infused into the law.

In the Pennsylvania case, Weinberg v. Sun Co., Inc., gasoline consumers brought a class action lawsuit against Sunoco under the state's Unfair Trade Practices and Consumer Protection law. ${ }^{311}$ The plaintiffs alleged that the company deceptively induced consumers to purchase its trademarked high-octane gasoline when their vehicles did

305. See generally Brief for the United States as Amicus Curiae Supporting Petitioners, Nike, Inc. v. Kasky, 539 U.S. 654 (2003) (No. 02-575), available at http://www.usdoj.gov/osg/briefs/ 2002/3mer/1 ami/2002-0575.mer.ami.pdf. Solicitor General Olson argued that the lack of "selflimiting principles" of common law actions, such as the requirement of actual injury and reasonable reliance, as well as the absence of "institutional checks" on government enforcement, such as political accountability and limited resources, may render private rights of action under CPAs unconstitutional in some circumstances. Id. at 12, 18. Ultimately, the Court did not reach the merits of the case. See Nike, 539 U.S. at 655 (dismissing the writ of certiorari as improvidently granted). Justice Breyer, joined by Justice O'Connor, dissented and would have decided the case. Id. at 66667 (Breyer, J., joined by O'Connor, J., dissenting). They found that "a private 'false advertising' action brought on behalf of the State, by one who has suffered no injury, threatens to impose a serious burden upon speech" and "can easily chill a speaker's efforts to engage in public debate." Id. at $679-80$.

306. 845 P.2d 685, 687 (Kan. 1993).

307. Id. at 688,691 .

308. Id.

309. Id. at 694.

310. Id. at 691-92.

311. 777 A.2d 442, 443-44 (Рa. 2001). 
not need it. ${ }^{312}$ In affirming the trial court's decision to deny class certification, the Pennsylvania Supreme Court found that "Commonwealth actions and private actions are distinguishable" in that the Attorney General may bring actions to restrain deceptive conduct "in the public interest," while private litigants must show an ascertainable loss as a result of a violation of the act. ${ }^{313}$ The court found nothing in the statute that authorized a private individual to attack an advertiser because consumers "might" be deceived. ${ }^{314}$ The court held that "[n]othing in the legislative history suggests that the legislature ever intended statutory language directed against consumer fraud to do away with the traditional common law elements of reliance and causation."315 Because each individual plaintiff would need to show that he or she heard and believed the advertising and purchased it for household (as opposed to business) purposes, and was damaged as a result, the court found class certification inappropriate. ${ }^{316}$ In so holding, the court accepted the defendant's argument that

while the attorney general may bring an action to restrain advertising which might "have a tendency to deceive a substantial segment" of the public and which is "likely to" influence purchasing decisions, private plaintiffs have no standing to bring actions in the public interest but must prove that they themselves were actually deceived and that the advertising actually influenced their purchasing decisions. ${ }^{317}$

There may be circumstances where there is a public need to address misrepresentations even where there has been no reliance. For example, a misleading Internet advertisement promoting a product that no one has actually bought might present such a situation. That need should be met by federal and state government enforcement of consumer protection statutes but not through civil claims for fraud. This is the government's proper role. The role of liability law, however, is to compensate people who have been actually harmed. ${ }^{318}$

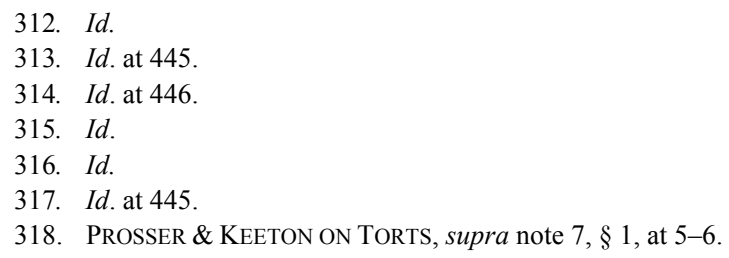




\section{Factoring in Culpability}

Fault has been a predicate throughout the history of liability law. This has been universally true when the basis for an award is punishment or deterrence. ${ }^{319}$ To some extent, CPAs have created a type of strict liability for advertising claims and any other conduct that can be considered unfair or deceptive. Some courts have ruled that a business may be liable for a violation of the statute regardless of whether it intended to deceive the consumer or commit the deceptive practice. Further, some states automatically impose not only actual damages but also statutory and treble damages even when plaintiffs failed to show that defendants were at fault. ${ }^{320}$

In this context, common sense dictates that courts require a showing of some degree of culpability. An Illinois appellate court agreed with this basic premise and found under the Illinois Consumer Fraud and Deceptive Business Practices Act that "not all misrepresentations are actionable; only those for which culpability can be shown." 321 There are several ways that this can be accomplished. First, particularly with respect to cases in which a consumer alleges that a business omitted or concealed a material fact, courts should not find that such an omission or concealment is a "deceptive act" unless the defendant intended to deceive the public or consumers relied on the missing information. ${ }^{322}$

Second, in states in which the law provides courts with discretion to award treble damages, courts should require proof that the defendant intended to deceive consumers as a predicate for punishment. For example, Alabama's statute provides that a court must consider several factors in deciding whether to award treble damages including: (1) "the amount of the actual damages awarded;" (2) "the frequency of the unlawful acts or practices;" (3) "the number of persons adversely affected thereby;" and (4) "the extent to which the unlawful acts or practices were committed intentionally." 323 Courts in states in which

319. See Prosser, WADE AND SChWARTZ, supra note 15, at 550 (discussing the use of punitive damages to punish and discourage bad acts).

320. See supra notes $120-22$ and accompanying text.

321. See Elson v. State Farm Fire \& Cas. Co., 691 N.E.2d 807, 817 (Ill. App. Ct. 1998) (affirming the dismissal of a claim under the Consumer Fraud Act where the plaintiffs did not plead with specificity the "deceptive act" component of the claim, including the defendant's knowledge of the misrepresentation or omission); see also Stern v. Norwest Mortgage, Inc., 688 N.E.2d 99, 104 (IIl. 1997) (finding no violation of the Consumer Fraud Act where the defendant made "an honest mistake" and had no intent to deceive or defraud the plaintiffs or to omit or conceal information with the intent that plaintiffs would rely on such action).

322. See supra notes $97-101$ and accompanying text.

323. ALA. CODE § 8-19-10(a)(2) (LexisNexis Supp. 2004). 
treble damages are discretionary can similarly incorporate an element of intent. Nevertheless, courts have chosen not to do so. ${ }^{324}$

In addition, where state laws provide for either automatic treble damages or statutory damages in excess of actual damages, or both, courts should read an intent requirement into the statute where the language of the law does not prohibit it.

Finally, where punitive damages are available, courts should be bound by the standards of evidence, level of culpability, and constitutional limitations applicable in all such cases. In addition, courts should follow the majority view that treble damages and punitive damages may not be awarded for the same conduct. ${ }^{325}$ Such duplicative awards raise significant constitutional issues and are fundamentally unfair. $^{326}$

\section{Requiring a Nexus Between the Misrepresentation and the Injury}

Apart from showing a plaintiff relied on the defendant's misrepresentation, courts utilizing common-sense interpretations of CPAs require plaintiffs to show that the misrepresentation was the proximate cause of their injuries. In other words, to bring a private right of action, individuals must be able to show that a business's alleged wrongful conduct led in a meaningful way to an economic loss; otherwise, the basic, fundamental difference between public law and private law is eliminated.

In Dura Pharmaceuticals, Inc. v. Broudo, the U.S. Supreme Court considered the need for a plaintiff to show causation in an analogous situation-under federal securities fraud actions. ${ }^{327}$ The Securities and Exchange Act of 1934 is similar to the FTC Act in that it prohibits "use or employ[ment]... [of] any ... deceptive device" in the purchase or sale of any security. ${ }^{328}$ Unlike the FTC Act, however, courts have found

324. See, e.g., Plath v. Schonrock, 64 P.3d 984, 990 (Mont. 2003) (finding that an award of treble damages under the Montana Consumer Protection Act does not require a showing that the defendant acted with malice, oppression, or fraud, but is determined on a case-by-case basis guided by the purpose of protecting the public from unfair or deceptive practices and making it economically feasible to bring civil actions).

325. See supra note 127 and accompanying text.

326. See Browning-Ferris Indus. v. Kelco Disposal, Inc., 492 U.S. 257, 279-80 (1989) (affirming a punitive damage award from judgment requiring plaintiff to choose between treble damage award and punitive damage award); John Mohr \& Sons, Inc. v. Jahnke, 198 N.W.2d 363, 367 (Wis. 1972) (finding that "to allow treble damages and punitive damages would amount to double recovery and [would] violate the basic fairness of a judicial proceeding").

327. 125 S. Ct. 1627, 1631 (2005).

328. 15 U.S.C. $§ 78$ j(b) (2000); see also 17 C.F.R. $§ 240.10 b-5$ (2005) (prohibiting the making 
an implied private right of action under the Securities and Exchange Act of 1934, and Congress "has imposed statutory requirements on that private action." 329 In Dura Pharmaceuticals, the Supreme Court considered whether a plaintiff could show loss causation simply by alleging that the price of the security was inflated on the date of purchase because of a misrepresentation. ${ }^{330}$ First, the Court restated the "basic" elements of a private right of action, which include "(1) a material misrepresentation or omission; (2) scienter, i.e., a wrongful state of mind; (3) a connection with the purchase or sale of a security; (4) reliance; (5) economic loss; and (6) 'loss causation,' i.e., a causal connection between the material misrepresentation and the loss.",331 It then emphasized the common law roots of a private right of action, observing that the purpose of securities statutes is not to provide "broad insurance against market losses, but to protect [purchasers] against those economic losses that misrepresentations actually cause." 332 Thus, the Court found that a plaintiff experienced no economic loss attributable to a misrepresentation simply because the market price might have been inflated at a particular moment in time. ${ }^{333}$ The Supreme Court did not permit plaintiffs' lawyers to twist a statutory action rooted in common law fraud, as are CPAs, into broad insurance policies or extended warranty programs. This decision should be a beacon for common-sense construction of CPAs.

\section{E. Upholding Traditional Requirements for Class Action Certification and Preventing a Windfall to Attorneys}

Class actions under state CPAs have become a favorite for plaintiffs' lawyers because of the potential for extraordinary damages for violations of a vague law. Class actions place tremendous pressure on businesses to settle regardless of the merits or whether class certification is appropriate because an unfavorable ruling-however misguided-could result in millions (or billions) of dollars in liability. ${ }^{334}$ For this reason, it

of any "untrue statement of ... material fact" or the omission of any material fact "necessary in order to make the statements made ... not misleading").

329. 15 U.S.C. § 78u-4(b)(4) (2000); Dura Pharm., 125 S. Ct. at 1631 (citing Blue Chip Stamps v. Manor Drug Stores, 421 U.S. 723, 730, 744 (1975)); Ernst \& Ernst v. Hochfelder, 425 U.S. 185, 196 (1976).

330. 125 S. Ct. at 1629.

331. Id. at 1631.

332. Id. at 1633 .

333. Id.

334. See, e.g., In re Rhone-Poulenc Rorer Inc., 51 F.3d 1293, 1298 (7th Cir. 1995) (recognizing that defendants in a class action lawsuit "may not wish to roll these dice. That is putting it mildly. They will be under intense pressure to settle"). 
is particularly important for courts to ensure fair treatment in class actions asserting private $\mathrm{CPA}$ claims.

The purpose of class actions is to provide an efficient vehicle for claim resolution where multiple plaintiffs have suffered nearly the same injury under the same law. ${ }^{335}$ The Federal Rules of Civil Procedure and analogous state rules permit class certification only when "questions of law or fact common to the members of the class predominate over any questions affecting only individual members." 336 This requirement ensures that class actions do not provide a mechanism to ignore fundamentals of tort law through aggregation of claims by allowing plaintiffs to prove liability through generic showings of elements of causes of action. ${ }^{337}$ In some cases, not only defendants but also plaintiffs could suffer from ill-conceived CPA class actions: for example, when a plaintiff's home state's CPA provides for greater relief than the forum state. $^{338}$ Thus, when individual issues such as reliance, damages, and applicable state law predominate, class certification is inappropriate because courts must decide these issues class member by class member. ${ }^{339}$

Courts in several states have properly construed class action rules and followed common sense in recognizing that class actions brought under CPAs are improper when individual factual or legal issues predominate. For example, in Philip Morris Inc. v. Angeletti, Maryland's highest court rejected a class action brought on behalf of all Maryland cigarette and smokeless tobacco users, a purported class of

335. See FED. R. CIV. P. 23(b)(3) advisory committee's note:

[The class action rule] encompasses those cases in which a class action would achieve economies of time, effort, and expense, and promote uniformity of decision as to persons similarly situated, without sacrificing procedural fairness or bringing about other undesirable results. ... In this view, a fraud perpetrated on numerous persons by the use of similar misrepresentations may be an appealing situation for a class action.... On the other hand, although having some common core, a fraud case may be unsuited for treatment as a class action if there was material variation in the representations made or in the kinds or degrees of reliance by the person to whom they were addressed.

(emphasis added). See also Amchem Prods., Inc. v. Windsor, 521 U.S. 591, 622-25 (1997) (ruling that an asbestos class action suit did not meet Rule 23(b)(3)'s predominance requirement because of the various individual issues present (e.g., differing levels of exposure) and disparities in state law).

336. Fed. R. Civ. P. 23(b)(3).

337. See Henry Schein, Inc. v. Stromboe, 102 S.W.3d 675, 693-94 (Tex. 2002) ("The procedural device of a class action eliminates the necessity of adducing the same evidence over and over again in a multitude of individual actions; it does not lessen the quality of evidence required in an individual action or relax substantive burdens of proof.").

338. See, e.g., id. at 695 ("Class members who live in states whose laws do not cap exemplary or statutory damages or require proof by clear and convincing evidence must suffer the limits imposed by Texas law .....').

339. Id. at 692-99. 
hundreds of thousands of people. ${ }^{340}$ Among the claims asserted by the class members was a claim that tobacco companies and their Maryland distributors violated several provisions of the Maryland Consumer Protection Act (MCPA). ${ }^{341}$ The court reasoned that individual issues, chiefly reliance, predominated over common issues with respect to the class's MCPA claims. ${ }^{342}$ "The unsuitability of such claims for class action treatment arises from the burden placed on [the class members] of proving individual reliance upon [Defendants'] alleged misrepresentations and material omissions ...." ${ }^{343}$ Noting how reliance could vary significantly from plaintiff to plaintiff, the court stated, "[s]uch individual discrepancies obviously cannot be glossed over at trial on a class-wide basis but must be allowed to be delved into by [Defendants], class member by class member." ${ }^{344}$

A ruling by the Supreme Court of Texas provides another example of how courts can properly evaluate the appropriateness of class action certification of private CPA claims. In Henry Schein, Inc. v. Stromboe, the court rejected a class action brought by some 20,000 dentists located in all fifty states against the makers of office management software. ${ }^{345}$ The complaint alleged several causes of action, including violations of the Texas Deceptive Trade Practices-Consumer Protection Act (TDTP). ${ }^{346}$ The court found that proof of reliance was a necessary element of a successful cause of action under the TDTP and that the class members failed to show that common issues of reliance predominated over individual ones. ${ }^{347}$ In so holding, the court remarked on how class actions cannot be used to avoid proving reliance, as required in an individual lawsuit:

\footnotetext{
340. 752 A.2d 200, 234-36 (Md. 2000).

341. Id. at 206 .

342. Id. at $234-36$.

343. Id. at 234 .

344. Id. at 236. Pennsylvania provides another example. In Weinberg v. Sun Co., the Pennsylvania Supreme Court rejected a class action brought under the Pennsylvania Unfair Trade Practices and Consumer Protection Law (PUTP) against a producer of high-octane gasoline because individual questions of fact predominated over common ones. 777 A.2d 442, 446 (Pa. 2001). The court held that "[t]he [PUTP] clearly requires, in a private action, that a plaintiff suffer an ascertainable loss as a result of the defendant's prohibited action." Id. The court clarified this holding: "That means, in this case, a plaintiff must allege reliance, that he purchased [the highoctane gasoline] because he heard and believed [Defendant's] false advertising that [the high-octane gasoline] would enhance engine performance." Id. See also notes 312-17 and accompanying text (discussing Weinberg).

345. 102 S.W.3d 675, 693-94 (Tex. 2002).

346. Id. at 680 .

347. Id. at 693 .
} 
[E]vidence insufficient to prove reliance in a suit by an individual does not become sufficient in a class action simply because there are more plaintiffs. Inescapably individual differences cannot be concealed in a throng. The procedural device of a class action eliminates the necessity of adducing the same evidence over and over again in a multitude of individual actions; it does not lessen the quality of evidence required in an individual action or relax substantive burdens of proof.

The court also found that damages - consequential, exemplary, and statutory-would have to be determined class member by class member. ${ }^{349}$ For example, to recover exemplary damages under the TDTP, class members must prove fraud, which requires proof of reliance, or malice, which requires proof of specific intent or subjective awareness of an extreme risk. ${ }^{350}$ As the court indicated, the defendants' conduct may have varied over the relevant periods. ${ }^{351}$ In addition, the court found that the class members failed to show that legal issues predominated, given the applicability of the laws of many states. ${ }^{352}$ As the court recognized, "[s]tate and federal courts have overwhelmingly rejected class certification when multiple states' laws must be applied." ${ }^{, 353}$

These decisions illustrate that class action certification is inappropriate if the case involves plaintiffs from multiple states because state CPA requirements and rules regarding class certification vary substantially. Indeed, as noted previously, some states do not allow class actions under their CPAs, ${ }^{354}$ and, even if the case involves class members from the same state, certification is inappropriate if individual factual issues such as reliance and damages predominate.

Because these deficiencies are common in attempted class actions involving CPAs, courts should only certify CPA classes in very limited circumstances: (1) when the plaintiffs are located in a single state and the CPA of one state applies; (2) when all class members were subject to precisely the same conduct; and (3) when damages are identical for each plaintiff, for example, when each was charged an undisclosed fee in an identical transaction.

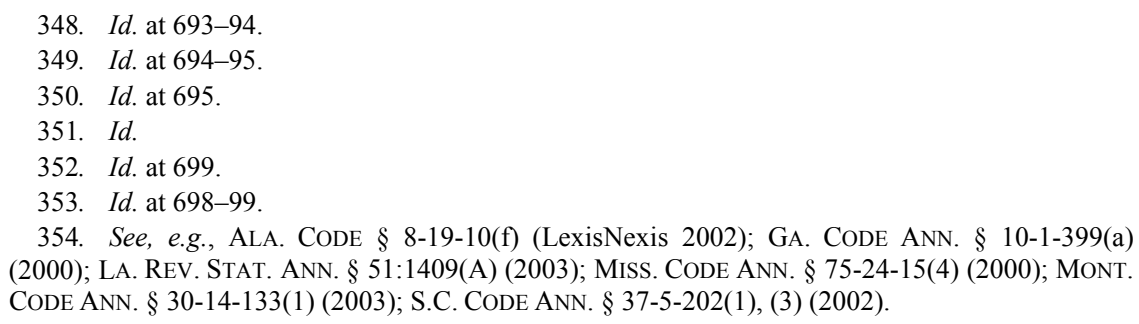


When CPAs allow for reasonable interpretation, such as where they do not specifically provide for the availability of class action lawsuits, courts that allow class action lawsuits ${ }^{355}$ should at least limit relief to actual damages. Statutory damages in class actions serve little purpose. Statutory damages were meant to provide an individual plaintiff with the ability to bring a lawsuit when the anticipated damages are otherwise too low to provide an attorney with adequate incentive to take a case. ${ }^{356}$ Similarly, class actions were meant to provide incentive to sue through the aggregation of claims when individual damages are otherwise too low. ${ }^{357}$ Thus, the incentive-creating effect of statutory damages is rendered duplicative when statutory damages are available in a class action. As a result, plaintiffs' lawyers, not plaintiffs, receive a windfall because they receive a percentage of the statutory fees multiplied by potentially thousands or millions of class members, even though statutory damages were unnecessary to create incentive to bring the suit. $^{358}$

\section{F. Placing Rational Limits on Extraterritorial Application}

To avoid forum shopping and to uphold principles of state sovereignty, courts should use a common-sense construction of CPAs and only apply them to conduct that occurred within the state in which they sit. Some courts have taken an unduly expansive view of the jurisdictional reach of their states' CPAs. Such rulings allow plaintiffs' lawyers to file claims in jurisdictions where the state CPA may provide for lower evidentiary standards or more generous relief. They may file such claims even though the conduct in question has only a tangential

355. See, e.g., In re Warfarin Sodium Antitrust Litig., 212 F.R.D. 231, 247-48 (D. Del. 2002), aff'd, 391 F.3d 516 (3d Cir. 2004); London v. Green Acres Trust, 765 P.2d 538, 545 (Ariz. Ct. App. 1988); Arthur v. Microsoft Corp., 676 N.W.2d 29, 37-38 (Neb. 2004); Super Glue Corp. v. Avis Rent A Car Sys., Inc., 517 N.Y.S.2d 764, 767-68 (N.Y. App. Div. 1987); Smith v. Behr Process Corp., 54 P.3d 665, 672-75 (Wash. 2002).

356. See Sovern, supra note 17, at 462 ("Consumer cases are typically for small stakes; that is why it is necessary to offer statutory, multiple, and punitive damages, and attorney's fees-because otherwise few consumers would sue.").

357. See Amchem Prods., Inc., v. Windsor, 521 U.S. 591, 617 (1997) (““The policy at the very core of the class action mechanism is to overcome the problem that small recoveries do not provide the incentive for any individual to bring a solo action prosecuting his or her rights. A class action solves this problem by aggregating the relatively paltry potential recoveries into something worth someone's (usually an attorney's) labor."' (quoting Mace v. Van Ru Credit Corp., 109 F.3d 338, 344 (7th Cir. 1997).

358. See, e.g., Washington v. Spitzer Mgmt., Inc., No. 81612, 2003 WL 1759617, at *5 (Ohio Ct. App. Apr. 3, 2003) (recognizing that Ohio's CPA authorizes class actions but limits recovery to actual damages "to protect defendants from huge damage awards in class actions"). 
relationship to the forum. These decisions undermine the public policy of sister states and invite inappropriate forum shopping.

When a local court in one state applies that state's law to regulate trade practices in another state, its intervention undermines all states' autonomy and ability to regulate conduct within their borders. In addition, when a court gives its state's CPA extraterritorial application, businesses may be penalized for a transaction that may have been perfectly legal in the state in which it occurred but that is found to violate a foreign court's interpretation of "unfair or deceptive" under another state law. For example, in Steed Realty v. Oveisi, a Tennessee appellate court held that plaintiffs from both Tennessee and Mississippi could bring an action under the Tennessee Consumer Protection Act arising out of transactions for real property located in Mississippi because the defendant "conducted trade and commerce in part in Tennessee by advertising and closing . . . real estate deals in [the] state." $" 359$

A number of highly respected courts have followed sound public policy and common-sense construction of CPAs. They have properly limited application of a state's CPA to conduct that occurred within that particular state. For example, in Nelson v. Nationwide Mortgage Corp., a federal district court found that the District of Columbia Consumer Protection Act did not reach a fraudulent loan issued by a Virginia corporation in Virginia even though it affected a resident of the District of Columbia. ${ }^{360}$ The court properly observed that "the District of Columbia statute would have to be given broad extraterritorial effect if it were to apply here." ${ }^{361}$ Similarly, in Shorter v. Champion Home Builders Co., a perceptive federal district court judge held that the Ohio Consumer Sales Practices Act is "only applicable if the offending conduct took place within the territorial boarders of the state of Ohio." 362

In August 2005, the Illinois Supreme Court unanimously overturned a \$1.2-billion, judge-issued verdict in Avery v. State Farm Mutual Automobile Insurance Co. involving out-of-state conduct. ${ }^{363}$ The case

359. 823 S.W.2d 195, 198 (Tenn. Ct. App. 1991). See also IDAHo CodE ANN. §§ 48-602(2), 603 (2003) (prohibiting deceptive practices either "within the state of Idaho, or directly or indirectly affecting the people of this state").

360. 659 F. Supp. 611, 616-17 (D.D.C. 1987).

361. Id. at 616 .

362. 776 F. Supp. 333, 338-39 (N.D. Ohio 1991). See also Oce Printing Sys. U.S., Inc. v. Mailers Data Servs., Inc., 760 So. 2d 1037, 1042 (Fla. Dist. Ct. App. 2000). In Oce Printing, a Florida appellate court refused to certify a nationwide class of plaintiffs seeking relief under the Florida Unfair Trade Act (FUTA). Id. The court concluded that FUTA was "enacted to protect instate consumers," and noted that, "“[o]ther states can protect their own residents." Id.

363. Avery v. State Farm Mut. Auto. Ins. Co., 835 N.E.2d 801 (Ill. 2005). 
was brought as a nationwide class action covering 4.75 million State Farm policyholders in forty-eight states. ${ }^{364}$ The plaintiffs alleged breach of contract and violations of the Illinois Consumer Fraud and Deceptive Trade Practices Act because of the insurer's practice of specifying the use of non-original equipment manufacturer parts (non-OEM parts) in auto repairs. ${ }^{365}$ Non-OEM parts are repair parts made by other companies that are not affiliated with the automobile companies, the "original equipment manufacturers." 366 Specifying non-OEM parts reduces repair costs and allows insurers to hold down the cost of automobile insurance premiums. ${ }^{367}$ According to one industry observer, non-OEM parts can be as much as forty percent cheaper. ${ }^{368}$ For this reason, Illinois and many other states expressly allow, and some states require, insurance companies to specify non-OEM parts, and no state prohibits the specification of non-OEM parts. ${ }^{369}$ The Illinois Supreme Court rejected nationwide class certification on the contract claims because the language of the insurance policies at issue varied from state to state and from policyholder to policyholder. ${ }^{370}$ The court also rejected class certification on the consumer fraud claims primarily because the class included out-of-state plaintiffs and repairs that occurred outside of Illinois: "The only putative class that can exist in this case under the Consumer Fraud Act is a class consisting of policyholders whose vehicles were assessed and repaired in Illinois."

\section{G. Preventing Conversion of Product Liability and Other Claims into CPA Claims}

Statutory actions under state CPAs and other claims are distinct causes of action. Yet, the vague language of CPAs has enticed some plaintiffs' lawyers who may be unable to prove the fundamental elements of another statutory action, a common tort claim, or a contract claim to

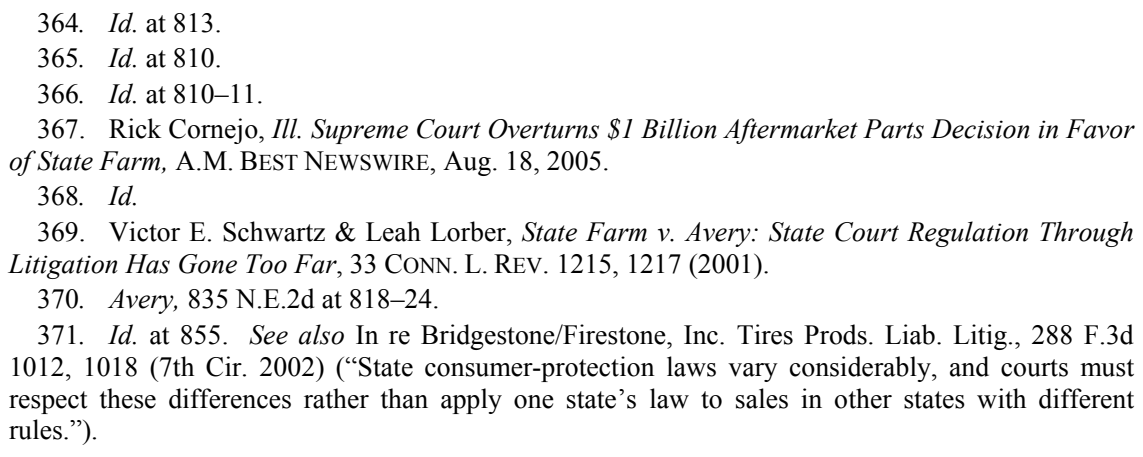
1012, 1018 (7th Cir. 2002) ("State consumer-protection laws vary considerably, and courts must respect these differences rather than apply one state's law to sales in other states with different rules.”). 
couch their lawsuit in CPA terms. ${ }^{372}$ This is a particular problem with respect to product liability lawsuits where a plaintiff who is unable to show a defective design alternatively alleges that a manufacturer is liable under a CPA because it misrepresented a product design, feature, or level of safety, or did not disclose certain risks or dangers associated with the product. $^{373}$

A recent example of this perilous trend is a group of class action lawsuits brought by fourteen residents and filed initially in eight states seeking \$5 billion from DuPont stemming from its use of the popular nonstick coat, Teflon. The CPA claims alleged that a chemical used in Teflon was dangerous and that DuPont failed to adequately warn consumers of the risk, despite no hard evidence that the chemical was harmful to humans when used in cookware. ${ }^{374}$ While this sounds like a typical product liability lawsuit, plaintiffs' lawyers quickly pointed out that they "'don't have to prove that it causes cancer," under CPAs, but only that the company kept information from the public. ${ }^{375}$ The lawsuits sought compensation to replace the pots and pans of most Americans ${ }^{376}$ and to establish two funds to pay for medical monitoring and scientific research. ${ }^{377}$ Such lawsuits do not appear to involve the everyday consumer transactions for which CPAs were anticipated. Rather, they appear to be product liability claims where lawyers would have difficulty showing that the product is unreasonably dangerous, that it caused any injury, or resulted in any loss to the plaintiff.

Despite suits of this nature, thus far, courts appear to have kept their collective finger in this dam. A Maryland case, Shreve v. Sears, Roebuck

372. See, e.g., Avery, 835 N.E.2d at 835-38 (finding that the plaintiffs' class action began as a claim for breach of contract, then was amended to add a statutory consumer fraud claim that did no more than restate the contract claim, and was amended yet again to focus on statements or actions during the claims process, rather than promises contained in the contract language, to avoid dismissal and maintain class certification).

373. See generally Philip E. Karmel \& Peter R. Paden, Consumer Protection Law Claims in Toxic Torts Litigation, 234 N.Y.L.J. 3 (2005) (examining CPA claims involving Teflon, cigarettes, and sport utility vehicles, and commenting that CPAs are the latest in a "recurring motif in toxic torts litigation" where innovative plaintiffs" attorneys seek to assert a product liability claim without the need to prove that their client was injured by the product).

374. See Amy Cortese, Will Environmental Fear Stick to DuPont's Teflon?, N.Y. TIMES, July 24, 2005, at 34 .

375. John Heilprin, DuPont Hit With \$5 Billion Suit Over Teflon Risks, Assoc. PrESS, July 20, 2005, available at http://www.law.com/jsp/article.jsp?id=1121763922530 (quoting plaintiffs' attorney Alan Kluger).

376. See Dawn McCarty, DuPont Sued Over Data on Teflon, PHILA. INQUIRER, July 20, 2005, at C7 (quoting plaintiffs' attorney Alan Kluger as stating, "[t]he class of potential plaintiffs could well contain almost every American that has purchased a pot or pan coated with DuPont's nonstick coating").

377. Heilprin, supra note 375. 
\& Co., ${ }^{378}$ provides an example. In that case, Mr. Shreve and his wife brought a product liability action against the manufacturer and seller of a snow thrower, alleging that he was injured while using the machine because of an alleged defect in a safety device incorporated into the design. ${ }^{380}$ The plaintiffs also alleged that the defendants committed an unfair and deceptive trade practice when they failed either to communicate to the plaintiff that the machine lacked an adequate guard or to depict the operation of the "impeller" blade, and when they committed other alleged misrepresentations in the owner's manual. ${ }^{381}$ The United States District Court for the District of Maryland granted summary judgment for the defendants. ${ }^{382}$ The court found that the mere sale of an allegedly defectively designed product was not a violation of the CPA. ${ }^{383}$ Only an implied warranty claim, the court found, fit the facts alleged by the plaintiffs. ${ }^{384}$ Plaintiffs' lawyers in Maryland have also tried to masquerade product liability claims as CPA claims in respect to a tobacco company's failure to inform the public of its ability to produce a "fire-safe" cigarette. ${ }^{385}$ This lawsuit met a similarly unsuccessful result. ${ }^{386}$ In that case, the court recognized that "if the Court were to accept Plaintiffs' theory, every product liability claim could also be converted into a claim under the MCPA." ${ }^{387}$ The Court found no authority for such an expansive application of the statute. ${ }^{388}$

The lawsuit that charged that OxyContin did not live up to its advertising claims as providing "smooth and sustained" relief provides another example of the use of CPAs to escape basic and well-reasoned requirements of product liability law. ${ }^{389}$ In that case, Williams v. Purdue Pharma Co., the dispute was essentially a product liability claim, yet the complaint alleged a violation of the District of Columbia's Consumer Protection Procedures Act. ${ }^{390}$ As the defendant observed, "[ $[\mathrm{t}]$ his is a product liability suit in which plaintiffs fail to allege any physical

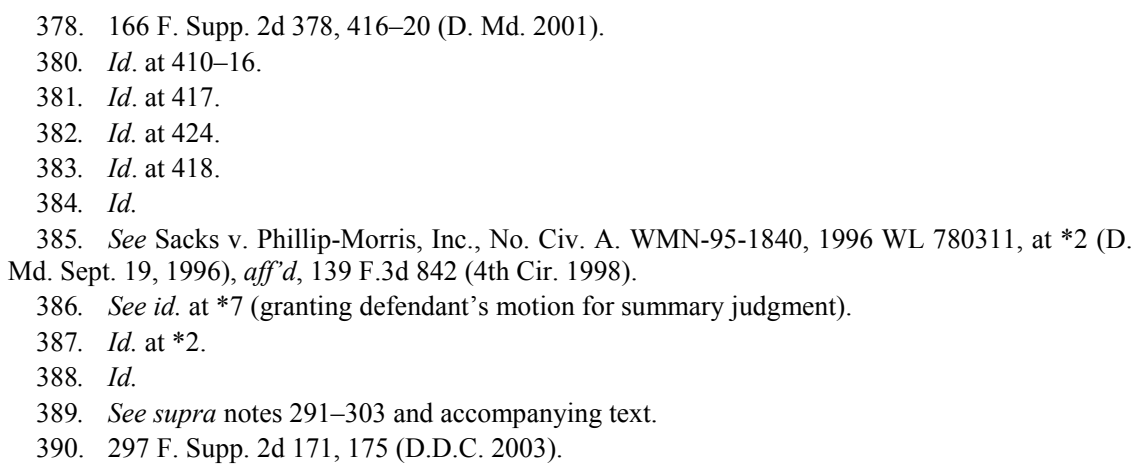


injury." $" 391$ Relying on a similar Texas case in which a plaintiff who was not injured sued a pharmaceutical manufacturer for not including warnings of the potential for liver damage and on grounds that the drug was defective on its labeling, the United States District Court for the District of Columbia agreed and dismissed the claim. ${ }^{392}$

Courts should continue to hold this common-sense line. When a claim sounds in product liability or contract law, or addresses an area traditionally addressed through enforcement of environmental or other statutory means, courts should not permit plaintiffs to use CPAs to eliminate well-reasoned requirements for a prima facie claim. The legislative history of CPAs clearly shows that they were meant to address typical consumer transactions, not product design or "unfair" practices in other areas.

\section{LEGISLATIVE INTERVENTION MAy Be NEEDED IN SOME STATES}

Although courts have a great degree of flexibility in interpreting CPAs, in some instances the plain language of the statute may limit a court's ability to adopt the common-sense interpretation suggested by this Article.

In some states, the elements of a claim are clearly set by statute. For example, the Delaware Consumer Fraud Act permits recovery "whether or not any person has in fact been misled, deceived or damaged thereby." ${ }^{393}$ District of Columbia law permits recovery for about thirty broadly described unfair trade practices regardless of "whether or not any consumer is in fact misled, deceived or damaged thereby." 394 North Dakota's statute requires an intent that others rely on a representation in connection with a sale or advertisement, "whether or not any person has in fact been misled, deceived, or damaged thereby."395 West Virginia law requires an intent that others rely on a statement in some cases, requires a "likelihood of confusion or of misunderstanding" in others, ${ }^{396}$ and does not require actual reliance by the consumer in any case. ${ }^{397}$

391. Id. at $175-76$.

392. See id. at 177-78 (citing Rivera v. Wyeth-Ayerst Labs., 283 F.3d 315 (5th Cir. 2002)).

393. Del. Code ANN. tit. 6, § 2513(a) (1999).

394. D.C. CoDE ANN. $\S \S 28-3904,-3905(\mathrm{k})(1)$ (LexisNexis 2001 \& Supp. 2005).

395. See N.D. CENT. CODE § 51-15-02 (1999) (stating that the use of "any deceptive act of practice, fraud, false pretense, false promise, or misrepresentation, with the intent that others rely thereon in connection with the sale or advertisement of any merchandise" is an unlawful practice).

396. W. VA. CodE ANN. § 46A-6-102(7) (LexisNexis Supp. 2005).

397. See id. § 46A-6-106(a) (allowing "any person who purchases or leases goods or services 
In other states, statutes require an award of treble damages ${ }^{398}$ or attorneys' fees ${ }^{399}$ to every prevailing plaintiff. Courts in such states may lack discretion to limit such awards based on whether the defendant knowingly or intentionally violated the statute, or to award some amount less than three times actual damages or full attorneys' fees where fairness dictates.

When courts find their hands tied by fossilized statutory language, legislators should intervene to restore common sense and respect the clear and sound divide between actions by government, which protect the public, and private causes of action, which should provide recovery only for real, individual harms. The elements of reform to restore this basic division will vary from state to state because of the diversity of CPAs. In general, essentials of CPA legislation should include the following provisions where needed to adjust statutory language:

- A showing that the plaintiff actually relied on the alleged misrepresentation and that the plaintiff's reliance was objectively reasonable;

- A requirement that the plaintiff show that he or she was actually injured with proof of monetary damages;

- Treble damages should be discretionary and not be awarded to every prevailing plaintiff regardless of whether the defendant acted intentionally or made an innocent mistake. Damages of up to three times actual damages may continue to be awarded if there is proof that the defendant intended to deceive the public. Legislation might set a "clear and convincing" evidence standard for an award of treble damages, consistent with many state laws providing for the award of punitive damages. Legislation might also clarify that punitive or exemplary damages are not available in private rights of action, as they are duplicative of treble damages;

- An award of reasonable attorneys' fees and costs to prevailing plaintiffs should continue to be available but should be discretionary, not required. A court should be able to award fees and costs to both prevailing plaintiffs and

\footnotetext{
and thereby suffers any ascertainable loss" as a result of an act declared to be unlawful to bring an action).

398. See supra note 120.

399. See supra note 130.
} 
defendants when it finds that exceptional circumstances warrant such an award;

- Where statutory damages (a minimum amount set by statute regardless of actual injury) are available, class action lawsuits should be prohibited. CPAs that continue to provide for class action relief should be amended to emphasize the need for class actions to meet ordinary civil procedure requirements, including the requirement that common issues of fact and law predominate over other issues in the lawsuit, such as individual reliance, causation, and damages. In no circumstance should statutory damages be available in class action lawsuits; and

- A statute of limitations that runs the greater of three years from the occurrence of the alleged unfair or deceptive act or violation of the statute or one year from when the consumer discovered or reasonably should have discovered a loss resulting from an act or practice declared unlawful by the CPA.

These principles are encompassed in model legislation recently developed by the American Legislative Exchange Council (ALEC), a non-partisan membership organization of state legislators. ${ }^{400}$ This "Model Act on Private Enforcement of Consumer Protection Statutes" is attached as an appendix. Again, courts can take the lead in restoring balance to CPAs through reasonable statutory interpretation. State legislators need only consider passing legislation when the language of the existing statute is so explicit that it does not provide sufficient judicial discretion or when the state judiciary has demonstrated a firm unwillingness to interpret that statute in a manner that reflects sound public policy.

\section{CONCLUSION}

There is a crucial difference between government enforcement of CPAs to protect the general public and private lawsuits that award damages to an individual. As Congress envisioned when it passed the FTC Act, if a business commits a trade practice found to be unfair or deceptive, it should be told to stop, and if it does not stop, it should be

400. For more information about ALEC, see http://www.alec.org. 
punished. Those injured by such practices should receive reimbursement reflecting their actual loss.

Private lawsuits operate very differently than government enforcement. Private lawsuits are retrospective and often impose damages in excess of actual damages. While fundamental elements of misrepresentation claims such as reliance, injury, and causation may be properly set aside when the government proactively seeks to stop an unfair or deceptive practice before someone is harmed, relieving private individuals of these requirements results in awards to those who have not been injured, and may not have even seen the representation at issue. Improper class action certification under CPAs can result in severe miscarriages of justice given the great diversity of state laws, the individual showing that should be required for each plaintiff, and the potential for attorneys to receive an extraordinary windfall for minor transgressions when statutory or treble damages are available or required.

The vague wording of CPAs often provides courts with clear publicpolicy choices. Most leave room for interpretation of the elements required to state a private cause of action, such as the need to show actual reliance. Several provide discretion as to when treble damages or attorneys' fees are to be awarded. Few specifically authorize class actions or discuss the availability of statutory damages in such cases. Courts should apply common-sense interpretations to CPAs that recognize the fundamental requirements of private claims, discourage forum shopping and extraterritorial application, and protect against CPAs morphing into a universal cause of action. When courts find that statutory language does not permit them to apply the law based on sound public policy that distinguishes between public law and private claims, state legislators should intervene. As this Article has shown, the overwhelming majority of California voters appreciated this vital distinction of law.

VIII. APPENDIX

\section{Model Act on Private Enforcement of Consumer Protection Statutes}

As Adopted by Unanimous Vote of the ALEC Civil Justice Task Force

State consumer protection statutes, frequently known as "unfair and deceptive trade practices acts," vary widely from state to state. ALEC's Model Act on Private Enforcement of Consumer Protection Statutes 
structures the private right of action under such laws to reflect sound public policy. Legislation based on the model act must be carefully drafted to fit within the state's existing statutory scheme. Crossreferences to the state's existing definition of an unlawful act or practice, optional language, and language that may be altered to fit the preference of the sponsor or consistency with state law are presented in brackets.

\section{Section 1. Private Right of Action.}

(a) A person who reasonably relies upon an act or practice declared unlawful by [SECTION] in entering into a transaction and thereby suffers an ascertainable loss of money or property may bring an action under this Act to enjoin further violations, or to recover as damages the out-of-pocket loss the person sustained as a result of such act or practice, or both. The "out-of-pocket loss" shall be no more than the difference between what the person paid for the product or service and what the product or service was actually worth in the absence of the unlawful act or practice.

(b) At least ten days prior to the commencement of any action brought under this section, any person intending to bring such an action shall notify the prospective defendant of the intended action, and give the prospective defendant an opportunity to confer with the person, the person's counsel, or other representative as to the proposed action. Such notice shall be given to the prospective defendant by mail, postage prepaid, to the prospective defendant's usual place of business, or if the prospective defendant has no usual place of business, to the prospective defendant's last known address.

IN STATES PROVIDING FOR AND OPTING TO MAINTAIN TREBLE DAMAGES, INCLUDE PARAGRAPHS (c) AND (d):

(c) If the [court OR trier of fact] finds by clear and convincing evidence that the use or employment of the act or practice declared unlawful by [SECTION] was willful with the purpose of deceiving the public, the court may award up to three (3) times the actual damages sustained[, or $\$ 500$ per person, whichever is greater].

(d) In determining whether to award enhanced damages under Subsection (b) and the amount of such penalty, the [court OR trier of fact] shall consider:

(1) if the amount of the actual damages awarded would have a deterrent effect upon the defendant;

(2) the seriousness of the violation, including the nature, circumstances, frequency, and gravity of any prohibited act or practice; 
(3) the history of previous violations;

(4) the good faith of the person found to have violated the Act, including whether the person took prompt and appropriate remedial action upon learning of the alleged violation; and

(5) any other matter that justice may require.

(e) Any person who is entitled to bring an action under Subsection (a) on his or her own behalf against an alleged violator of this act for damages for an act or practice declared unlawful by [SECTION] may bring a class action against such person on behalf of any class of persons of which he or she is a member and which has been damaged by such act or practice, subject to and pursuant to the [STATE] Rules of Civil Procedure governing class actions. [In any such class action, the court shall not award statutory damages, but recovery shall be limited to actual out-of-pocket loss suffered by the person or persons.] ${ }^{401}$ This paragraph is not intended to create or otherwise permit class action relief where not permitted by state law. ${ }^{402}$

(f) Punitive or exemplary damages are not permitted in an action maintained under this Section.

\section{Section 2. Attorneys' Fees and Costs.}

The court may award reasonable attorneys' fees and costs to:

(a) A prevailing plaintiff upon a finding [by the court OR trier of fact] that the defendant's use or employment of the act or practice declared unlawful by [SECTION] was willful with the purpose of deceiving the public,

(b) A prevailing defendant upon a finding by the court that the action was groundless in fact or law or brought in bad faith, or brought for the purpose of harassment.

\section{Section 3. Limitation of Actions.}

No action may be brought more than one (1) year after the person bringing the action discovers or reasonably should have discovered a loss resulting from an act or practice declared unlawful by [SECTION], but in no event may any action be brought under this chapter more than [four

401. This provision is needed only in states that opt to provide statutory damages, a minimum award to the plaintiff regardless of the actual injury. The model act does not provide for statutory damages but fully compensates plaintiffs for any out-of-pocket loss.

402. Legislation in states that do not currently permit class action lawsuits under their consumer protection statute should not include paragraph (e). 
(4)] years from the first instance of the act or practice giving rise to the cause of action.

\section{Section 4. Exemptions.}

(a) Nothing in this Act shall apply to:

(1) Acts or practices required or permitted by or in accord with state or federal law, rule or regulation, judicial or administrative decision, or formal or informal agency action;

(2) Acts or practices by the publisher, owner, agent or employee of a newspaper, periodical, radio or television station or any other person without knowledge of the deceptive character of the advertisement in the publication or dissemination of an advertisement supplied by another; or

(3) Acts or practices by a retailer who has, in good faith, engaged in the dissemination of claims of a manufacturer or wholesaler without actual knowledge that it violated the Act.

[(b) Nothing in this Act is intended to create a claim or remedy for a violation of a state or federal law, rule or regulation where the legislature did not establish a private right of action. $]^{403}$

403. This language is needed in states in which courts have permitted use of consumer protection statutes to effectively create private rights of action under other statutes or regulations where the legislature did not intend to allow private lawsuits. 